\title{
5. SITE 369: CONTINENTAL SLOPE OFF CAPE BOJADOR, SPANISH SAHARA
}

\author{
The Shipboard Scientific Party ${ }^{1,2}$
}

\section{SITE DATA}

Date Occupied: 23 March 1975 (2335)

Date Departed: 26 March 1975 ( 050)

Time on Site: 2 days, 21 hours, 15 minutes

Position: $26^{\circ} 35.5^{\prime} \mathrm{N}, 14^{\circ} 59$. 'W

Water Depth (sea level): 1752 corrected meters (echo sounding)

Bottom Felt With Drill Pipe at: 1770 meters

Penetration: 488.5 meters below rig floor

Number of Holes: 2

Number of Cores: 52

Total Length of Cored Section: 488.5 meters

Total Core Recovered: 386.4 meters

\section{BACKGROUND AND OBJECTIVES}

Site 369 was the first site to substantially penetrate a continental slope. A previous attempt had been made during Leg 11 (Site 108) on the North American continental slope, but technical difficulties allowed recovery of only two cores (Hollister, Ewing, et al., 1972). The nature of the sediment recovered in these cores-Eocene siliceous and carbonate pelagic chalk, almost devoid of terrigenous material-contrasts sharply with the hemipelagic nature of the Quaternary sediments sampled by piston coring. The sedimentation processes involved in the evolution of a continental slope are very poorly known. This physiographic province is located between two domains (shelf and rise) that are generally characterized by thick sediment accumulations related to the subsidence of both areas. The slope itself is believed to be a region where

'Yves Lancelot, Lamont-Doherty Geological Observatory, Palisades, New York (Co-Chief Scientist); Eugen Seibold, Geologisch-Palaontologisches, Institüt und Museum der Universität Kiel, Kiel, Germany (Co-Chief Scientist); Pavel Čepek, Bundesanstalt für Bodenforschung, Hannover, Federal Republic of Germany; Walter E. Dean, Syracuse University, Department of Geology, Syracuse, New York; Vladislav Eremeev, Institute of Geological Sciences of the Academy of Sciences, Laboratory of Lithology Formation, Moscow, USSR; James Gardner, Deep Sea Drilling Project, Scripps Institution of Oceanography, La Jolla, California; Lubomir F. Jansa, Atlantic Geoscience Centre, Geological Survey of Canada, Bedford Institute of Oceanography, Dartmouth, Nova Scotia; David Johnson, Woods Hole Oceanographic Institution, Woods Hole, Massachusetts; Valery Krashneninnikov, Geological Institute of the Academy of Sciences of the USSR, Moscow, USSR; Uwe Pflaumann, GeologischPalaontologisches, Institut und Museum der Universität Kiel, Kiel, Germany; J. Graham Rankin, Northeast Louisiana University, Department of Chemistry, Monroe, Louisiana; Peter Trabant, Texas A\&M University, Department of Oceanography, College Station, Texas.

${ }^{2}$ David Bukry, U.S. Geological Survey, La Jolla, California (Tertiary nannofossils).

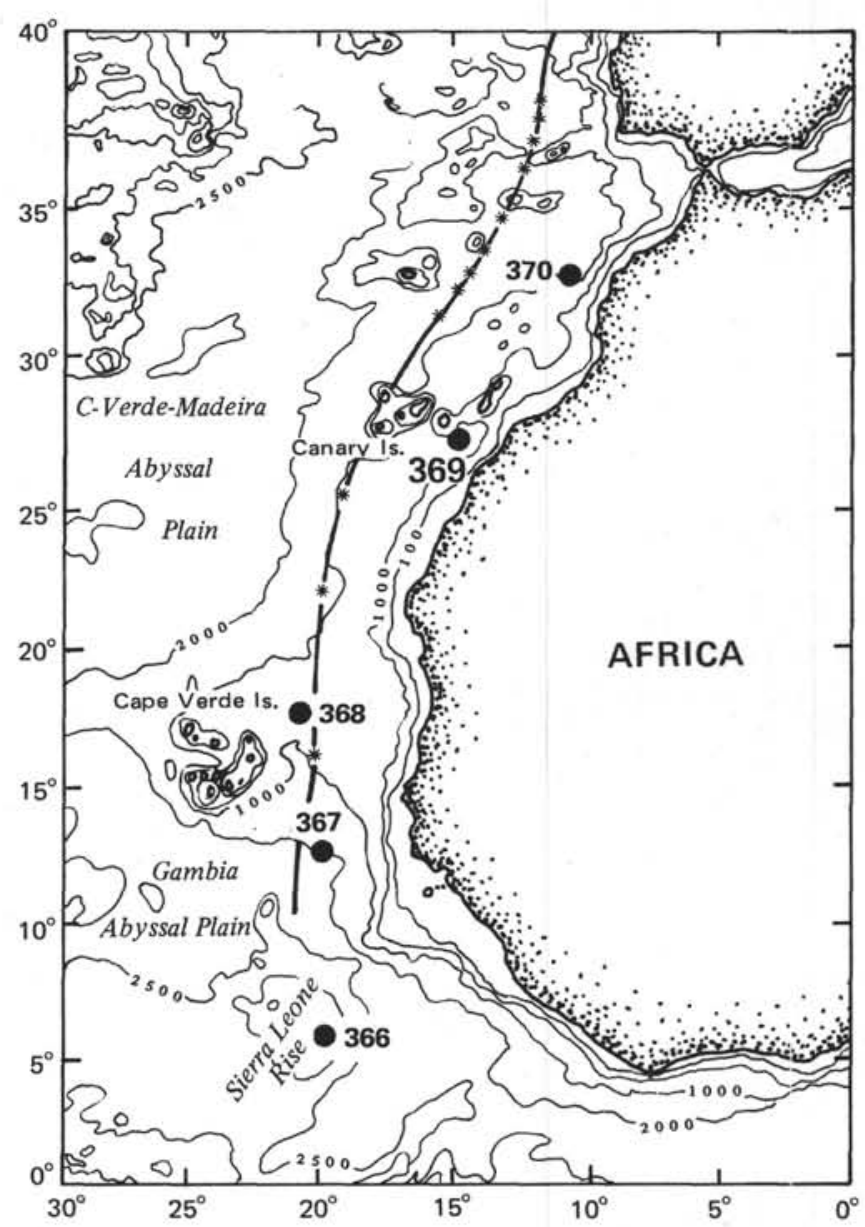

accumulation is quantitatively much less important and where erosion processes, by currents or by massive slumping, are and should have been very active so that it would have remained a permanent topographic feature during the evolution of the continental margin.

The structural factors responsible for the location and the morphology of the continental slopes of the "Atlantic" (rifted, passive) type are also poorly known. Geophysical data generally suggest the presence, beneath the slope, of a structural high that has been alternatively interpreted as a zone of massive basic intrusions, salt diapirs, edge of a rifted continental crustal block, or a carbonate platform and reef system (possibly associated with a basement high). This structural high appears particularly outstanding, being located between two zones of high subsidence.

The evolution of a continental slope of the "Atlantic" type is therefore relatively complicated because it is believed to result from a combination of factors among which subsidence, sedimentation, erosion, structural control, and possibly tectonic deformation are probably determinant. The nature of 
the sediments found beneath the slope should provide a guide to interpret this evolution. In particular, if shallow water facies are encountered, the subsidence history of the margin could be deciphered by direct comparison with the sedimentary evolution of the continental shelf.

\section{The Continental Slope Off Spanish Sahara}

Seibold and Hinz (1974) conducted several detailed surveys on the North African continental margin. One of these surveys, off Cape Bojador, provided the basic information for the selection of Site 369. What makes this area particularly interesting is (1) the possibility of tying drilling results with those of several wells drilled on shore nearby, and (2) a very good set of parallel seismic reflection profiles providing particularly good structural control for this site.

Site 369 is located on a northwest-southeast profile (see location on Figure 1) that shows the presence of two main reflectors, named $\mathrm{D}_{1}$ and $\mathrm{D}_{2}$ (Figure 2), roughly parallel to the sloping sea bottom and overlying an anticline structure. Both reflectors $D_{1}$ and $\mathrm{D}_{2}$ appear to correspond with some angular unconformity. They have been tentatively correlated regionally with major unconformities recorded in the Spanish Sahara drill holes (Hinz et al., 1974; Seibold and Hinz, 1974). The upper reflector $\left(D_{2}\right)$ was believed to correspond with an Oligocene/early Miocene unconformity; and the lower one $\left(D_{1}\right)$ was believed to correspond with a Cenomanian unconformity. Between these reflectors and between $\mathrm{D}_{2}$ and the sea floor, no obvious major slumping can be observed on the profiles although some are evident in the uppermost part of the slope. The anticline structure, named slope anticline, is particularly interesting because although such a structure is often indirectly inferred to be present beneath the continental slope in many areas of the Atlantic, it is very rarely observed on single-channel unprocessed seismic reflection profiles. Naturally the anticline structure visible off Cape Bojador (which can be followed down to about $24^{\circ}$ of latitude and is present also off Cape Blanc) is probably the surficial expression of a deep-seated structure such as a basement high (continental or oceanic), a reef system, salt diapirs, etc., which cannot be seen on the reflection profile. Such a continuous anticline structure is of course of special interest for economical aspects because if it is connected with source rocks beneath either the shelf or the rise, and if it consists of shallow water deposits with possible high porosities, it could have favored exploitable hydrocarbon accumulations. Such a potential then led us to extra caution in the planning of the operations for Site 369 .

\section{Safety Aspect of Drilling on the Continental Slope}

Because of the possibility of encountering shallow water sediments having possible high porosities, of hydrocarbons reported in on-land drill holes, and of the presence of both unconformities and a closed structure, the safety aspect of drilling at Site 369 is of particular importance. The recommendations from the JOIDES Advisory Panel of Safety and Pollution Prevention for Site 369 were to avoid drilling near the top of the closed structure and limit total penetration to 700 meters below the sea floor. In addition, very closely spaced coring would be performed and all cores would be monitored for possible traces of hydrocarbons.

Site 369 had been selected in a location as far away as possible from the top of the anticline structure and still with a relatively thin sediment cover above the

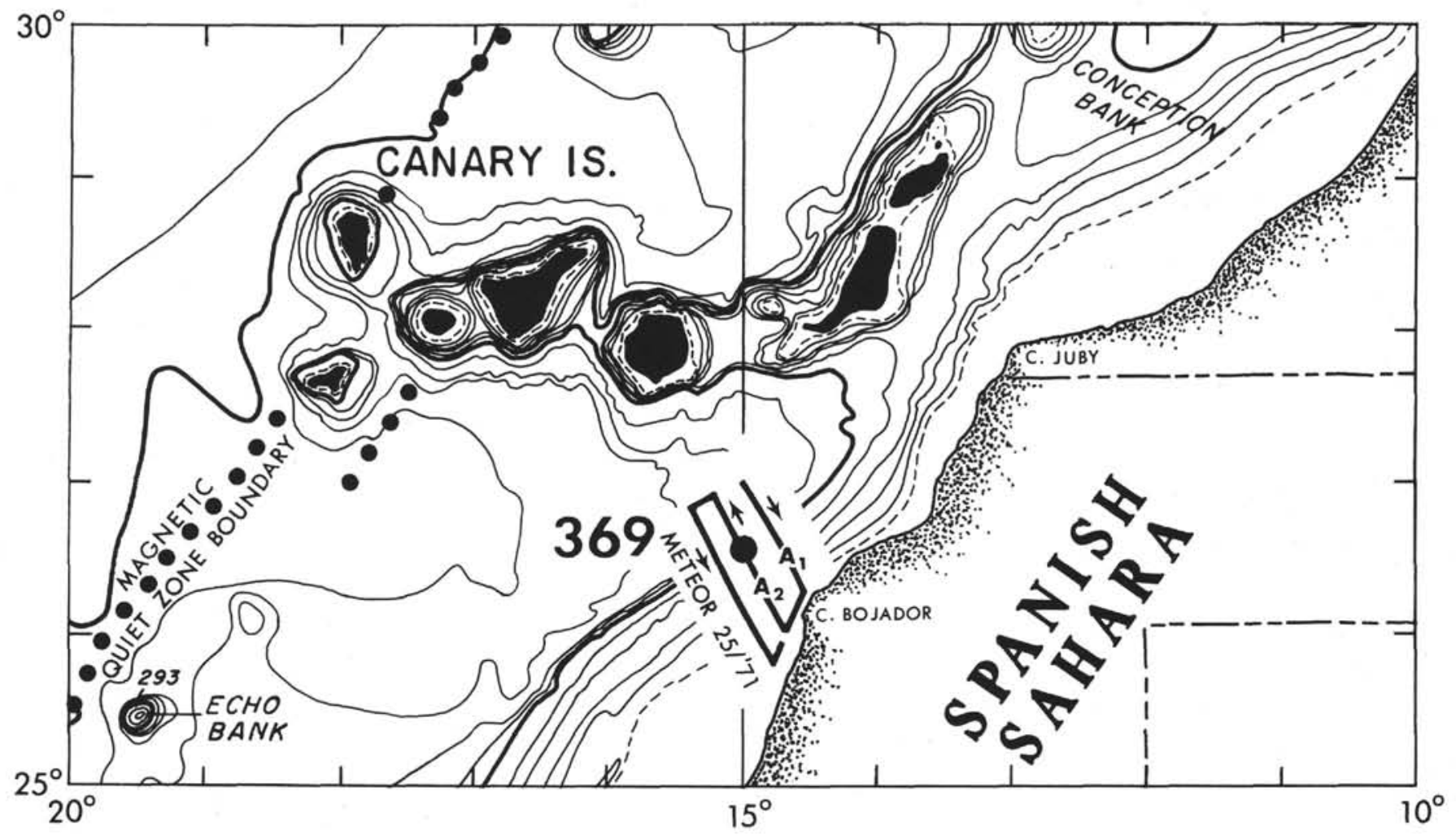

Figure 1. Location of Site 369 off Spanish Sahara. Bathymetry from Uchupi (1971). 
unconformities. Figure 3 shows that when the original profile (Figure 2) is corrected for assumed interval velocities, the top of the anticline structure lies seaward of Site 369. It is believed that the relatively thin sediment cover represents an additional safety precaution. Furthermore, the presence of erosional unconformities below that thin sediment cover suggests that most of the eventually trapped hydrocarbons could have escaped from the structure sometime during the Late Cretaceous and then during the Oligocene/Miocene times.

As additional safety measures, it was decided to core continuously and, if gas was found within the sediments, then the methane/ethane ration was to be continuously monitored. In the absence of specific quantitative guidelines, and on the basis of the experience gained from the base of Site 368, as well as shipboard data from Leg 40, we decided to consider that the hole would be abandoned should the methane/ethane ratio reach values as low as 500 .

\section{OPERATIONS}

The general area of Site 369 was approached from the southwest on a $028^{\circ}$ course until the reference Meteor 25/1971 seismic reflection profile was intercepted at a Meteor satellite navigation position about $35 \mathrm{~km}$ northwest of the site (Figure 4). The interception point was reached at 1940 on 23 March 1975 , and the ship turned to a heading of $150^{\circ}$ to follow the Meteor track. At 2135 the speed was reduced to approximately 6 knots. In order to select the most suitable position for the site, it was decided to make a run over the proposed location with the seismic gear operating and then come back over the site and drop the beacon. This maneuver was completed at 2235 when a 13.5-kHz ORE beacon was dropped. The gear was retrieved immediately and the ship executed another Williamson turn to a position over the beacon at $26^{\circ} 35.5^{\prime} \mathrm{N}$ and $14^{\circ} 59.9^{\prime} \mathrm{W}$. The "lock on" was effective at 2335 . The PDR water depth was recorded at 1752 meters corrected. Drill pipe was lowered and the bottom was felt by the driller when the total length of the drill string reached 1770 meters from the rig floor. The water depth of 1760 meters is considered as the official one. The discrepancy between the drill pipe and PDR water depths can be explained by a relatively rough sea-floor topography.

Coring operations started immediately and five cores were punched successively down to 42 meters subbottom. After retrieving Core 5, acoustics were lost temporarily on the dynamic positioning system, causing a relatively large excursion of the ship over the site. Because of the relatively shallow water depth, such an excursion was critical and the drill string was pulled out of the hole clear of the mud line. After restabilizing the ship over the beacon and regaining the acoustics, the drill string was lowered again and a new hole (369A) was washed down to 42 meters below the sea floor, exactly at the level reached in the previous hole. Continuous coring was resumed and performed without incident until a total depth of 488.5 meters was reached. Several cores above that level contained gas that was continuously sampled and analyzed for hydrocarbon content. The gas contained in Core 47 had a methane/ethane ratio of 610 and the presence of small amounts of gaseous butane were noted. Although the total amount of gas in the sediment did not appear alarming, the possibility of encountering shallowwater, high-porosity facies below the level reached at that time, together with the immediate vicinity of an anticline structure, dictated our decision to discontinue the coring. The hole was plugged with cement and mud and the drill string was retrieved. The drill bit was found almost intact. A total of 47 cores were cut in Holes 369 and 369A, representing the complete section (488.5 meters), out of which 386.4 meters $(79 \%)$ were recovered (see Table 1). The post-site survey consisted of a run over the beacon at approximately 6 knots on a course almost perpendicular to the approach course and course was set and cruise speed resumed toward Site 370 .

No sonobuoy record was attempted at this site.

\section{LITHOLOGY}

We subdivided the section into three units and a total of five subunits based on composition and color. Table 2 summarizes the lithologic sequence at Site 369.

\section{Unit 1}

Subunit 1a-Nannofossil Marl (Cores 1 through 9A):

Subunit 1a is characterized by a dominant greenish gray color (5GY8/1) and sparse siliceous microfossils (radiolarians, diatoms, and sponge spicules). Glauconite, detrital silt, carbonate rhombs (calcite, siderite, and/or dolomite?), and ferromanganese (?) flecks and micronodules are all very rare. Abundant volcanic glass shards and pumice occur as thin $(<1 \mathrm{~cm}$ thick) beds and laminae in Cores $2 \mathrm{~A}$ through $5 \mathrm{~A}(51.5$ to $89 \mathrm{~m})$. Thin $(0.5 \mathrm{~cm})$ silt lenses occur in Cores 8 and 9. Bioturbation is apparent throughout this subunit.

\section{Subunit 1b-Siliceous Nannofossil Marls} (Cores 10A through 33A):

Subunit $1 \mathrm{~b}$ differs from Subunit $1 \mathrm{a}$ in color and abundance of siliceous fossils. The dominant colors are olive-gray (5Y3/2) becoming dusky yellow-brown $(5 \mathrm{GY} 5 / 2)$ in Core 19A. The predominant lithology is siliceous nannofossil marl with common radiolarians and diatoms and rare foraminifers.

Glauconite, detrital silt, carbonate rhombs, ferromanganese micronodules and flecks, volcanic glass, and clinoptilolite are rare components of Subunit $1 \mathrm{~b}$. Fossil hash is scattered throughout the sediment from Cores 14A through 16A. Slumping is apparent from Cores $27 \mathrm{~A}$ to $41 \mathrm{~A}$. This subunit is bioturbated throughout, with some burrows filled with pyrite.

\section{Unit 2}

\section{Subunit 2a-Argillaceous Nannofossil Chalk and Limestone} With Chert and Porcellanite (Cores 33A through 37A)

The predominant lithofacies of Subunit $2 \mathrm{a}$ is an argillaceous nannofossil chalk (33A, Sections 1 through 3) and argillaceous nannofossil limestone (Cores $33 \mathrm{~A}$, Section 4 , to $36 \mathrm{~A}$ ) with thin ( 2 to $4 \mathrm{~cm}$ thick) interbeds of chert, and nodules and stringers of porcellanite 


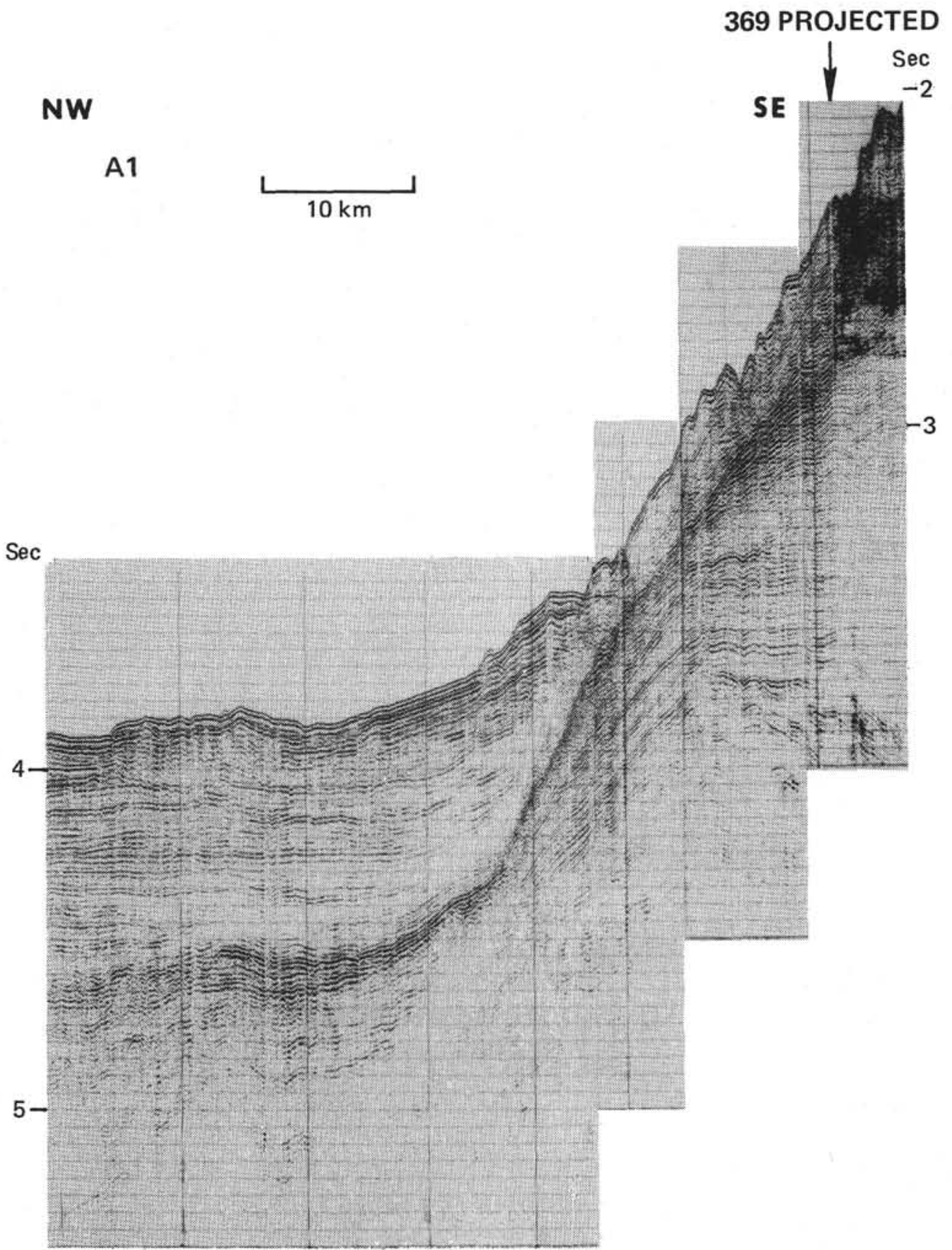

Figure 2a. Seismic-reflection profile from Meteor cruise 25-1971, line A1 (see Figure 1).

scattered throughout. The sediments are dominantly light gray (N8) and bioturbated with various shades of light greenish gray (5GY8/1) chalk filling the burrows. Ameboid-shaped mottles (Figure 5) of light gray color occur throughout this subunit. It is uncertain whether these mottles are burrows or a diagenetic feature. However, definite trace fossils (especially Zoophycos) are common. Light gray chert and porcellanite, where present are restricted to light gray limestone. The dominant cement of the limestone is microsparite.

\section{Subunit 2b-Argillaceous Chalk (Cores 38A through 40A)}

The lithology of Subunit $2 \mathrm{~b}$ is a greenish gray $(5 \mathrm{G} 6 / 1)$, bioturbated argillaceous chalk with all of the components found in Subunit $2 \mathrm{a}$, but the chalk is not cemented. A transition zone between chalk of Subunit $2 \mathrm{~b}$ and marl and chalk of Unit 3 begins in Core 38 $(393.5 \mathrm{~m})$. Slumps are scattered within this subunit.

\section{Unit 3-Silty Nannofossil Marl and Chalk (Cores 41A} through $47 \mathrm{~A}$ )

The dominant lithologies of Unit 3 are silty nannofossil marl and chalk with rare, scattered, barite crystals (partially to completely replaced by calcite). The silt components are composed of quartz, feldspars, heavy minerals. The dominant color is olive-black $(5 \mathrm{Y} 2 / 1)$ with dark greenish gray $(5 \mathrm{G} 4 / 1)$ interbeds. The unit is bioturbated throughout and has several 


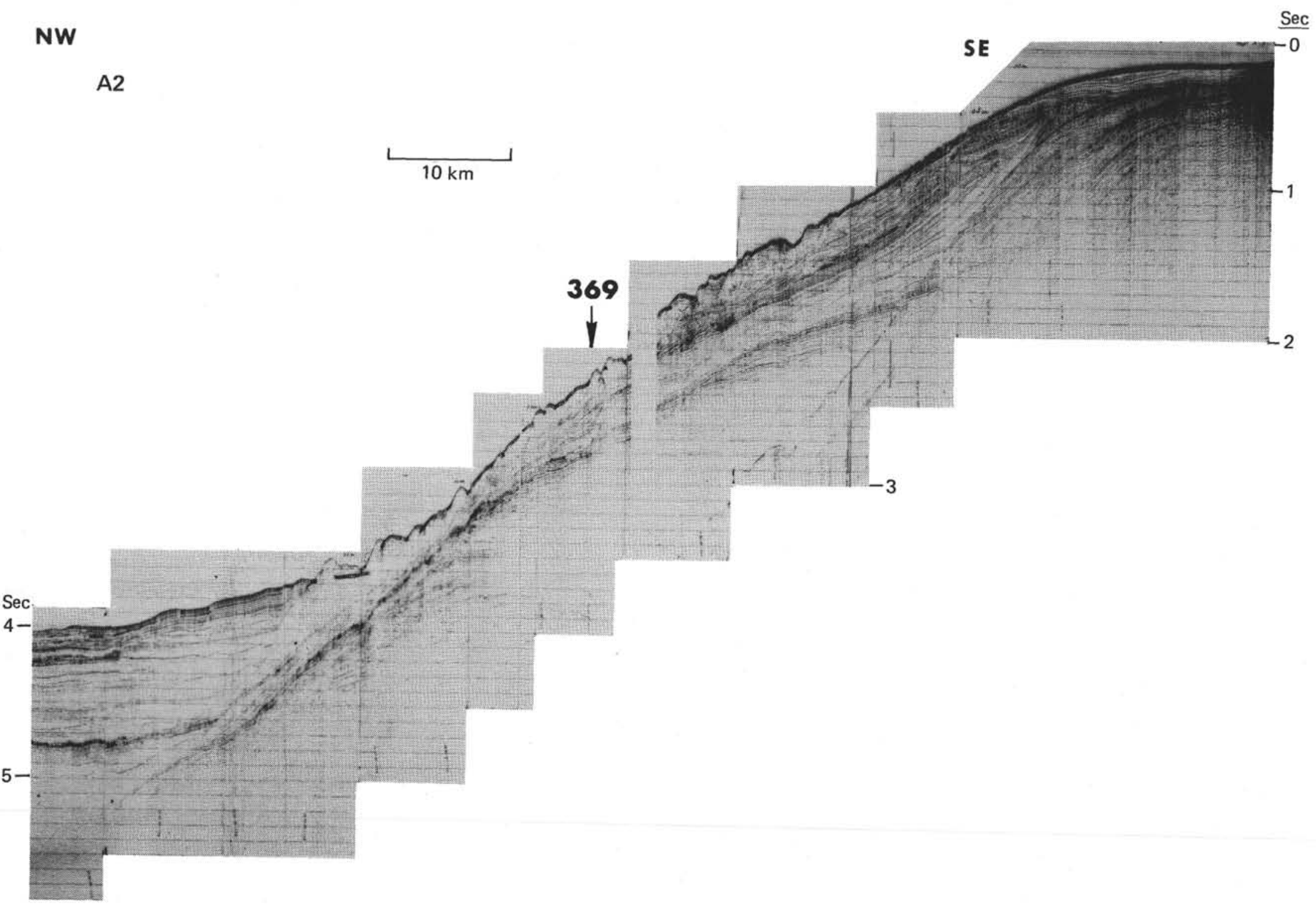

Figure 2b. Seismic-reflection profile from Meteor cruise 25-1971, line A2 (see Figure 1). 


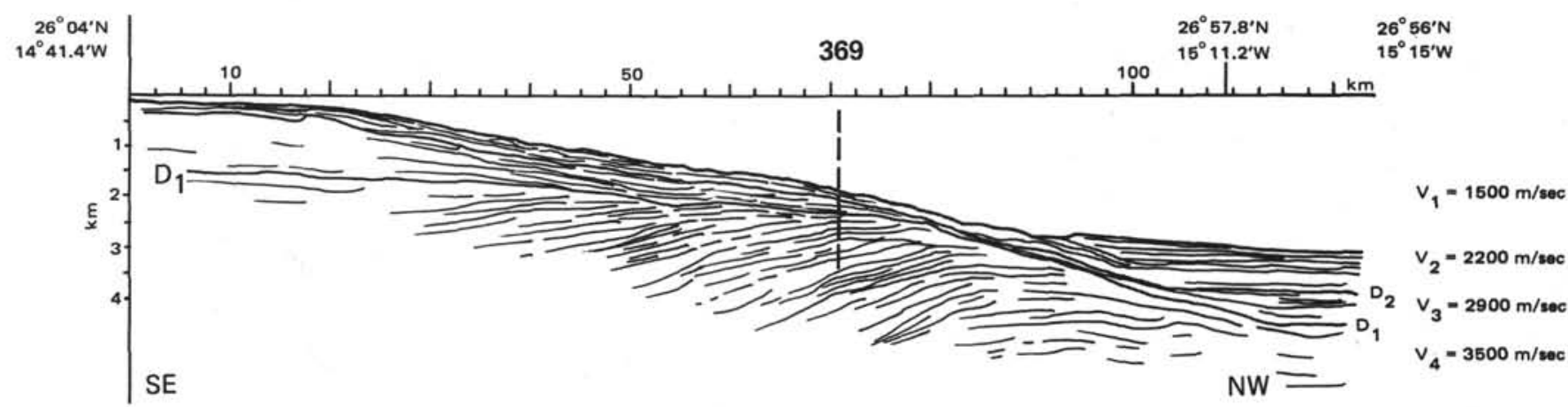

Figure 3. Line drawing of vertically-migrated seismic-reflection profile of Figure 2b (line A2) from Seibold and Hinz (1974). Interval velocities used for computation are indicated on the right.

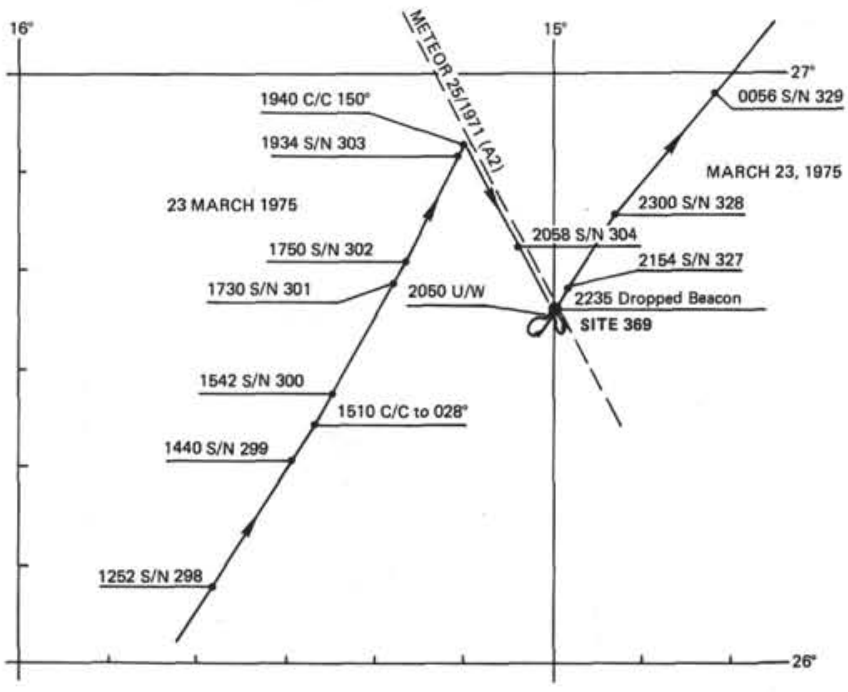

Figure 4. Tracks of Glomar Challenger approaching and leaving Site 369. Dashed line is track corresponding with Meteor reference profile.

zones, each 5 to $15 \mathrm{~cm}$ thick, of finely laminated barite, calcite, and dark reddish-brown organic matter. In addition, a few zones of graded equigranular calcite crystals occur as 20 to $30 \mathrm{~cm}$ thick interbeds. Pyrite is found disseminated throughout, and as thin $(0.5 \mathrm{~cm})$ stringers, especially in Core 41 . Belemnite fragments occur in Cores 42 and 43 . Barite rosettes $(>2 \mathrm{~cm})$ and laminae $(<1 \mathrm{~cm})$ are found in Cores 43 to 45 (Dean and Schreiber, this volume). All of the sediments of this unit are gas bearing (see Geochemistry section for details).

\section{Summary}

Surprisingly, the sediments recovered comprise a more pelagic than hemipelagic facies, having abundant planktonic faunas and floras and only a rare coarse detrital component. These observations are similar to those made by the Leg 11 sedimentologists of samples from Site 108 on the North American continental slope (Hollister, Ewing, et al., 1972). The major lithology throughout the section is an argillaceous nannofossil marl with variable siliceous biogenic, volcanic ash, chert and porcellanite, and clay components. Detrital silt, ferromanganese(?) flecks and micronodules, carbonate rhombs (calcite, siderite, and/or dolomite?), and fish debris are persistent but rare components.
Slump features, such as inclined and contorted beds, plastic flow, microfractures, and thick sequences of mixed, chaotic lithologies, occur in the lower part of the section. The complete section is bioturbated, most commonly by Zoophycos and Chondrites.

We found no definitive indicators of shallow-water deposition, as predicted by Seibold and Hinz (1974), for the Cenomanian to the Oligocene interval. We did find volcanic ash horizons in the late and middle Miocene section which correlate with periods of volcanism on the Canary and Cape Verde Islands and western Senegal (see Gardner et al., this volume; Furon, 1963; Dillon and Sougy, 1974; Grunau et al., 1975).

\section{GEOCHEMICAL MEASUREMENTS}

A description of the analytical techniques used in the geochemical analyses is given in the Introduction to this volume.

\section{Organic Carbon and C/N Ratios}

Because of the short duration of this site and continual monitoring of interstitial gas, few organic carbon samples were processed. Samples that were completed are given in Table 3.

\section{Interstitial Gas}

Cores showing efferescence or bulging end caps were sampled for light hydrocarbon analysis. No gas was evident in the five cores retrieved from Hole 369 before it was abandoned. All data listed in Table 4 are for Hole 369A. Gas was observed in Cores 3A, 23A to 33A, and from Cores $40 \mathrm{~A}$ to $47 \mathrm{~A}$.

\section{Carbonate Bomb}

Results of carbonate analyses using the carbonate bomb apparatus are given in Table 5 and Figure 6.

\section{Interstitial Water Geochemistry}

Results of interstitial water geochemistry are given in Table 6 and Figure 7. The salinity gradient shows an increasing trend with depth. This could be indicative of a possible salt deposit within the unsampled sediment section with slow diffusion upward. However, such a deposit must have been considerably below our maximum drilled depth $(488.5 \mathrm{~m})$ because the increase is not as high as has been found adjacent to salt domes or evaporite deposits on previous legs. 
TABLE 1

Coring Summary for Site 369

\begin{tabular}{lccccccc}
\hline Core & $\begin{array}{c}\text { Date } \\
\text { (March 1975) }\end{array}$ & Time & $\begin{array}{c}\text { Depth From Drill } \\
\text { Floor }(\mathrm{m})\end{array}$ & $\begin{array}{c}\text { Depth Below } \\
\text { Sea Floor }(\mathrm{m})\end{array}$ & $\begin{array}{c}\text { Cored } \\
(\mathrm{m})\end{array}$ & $\begin{array}{c}\text { Recovered } \\
(\mathrm{m})\end{array}$ & $\begin{array}{c}\text { Recovered } \\
(\%)\end{array}$ \\
\hline Hole 369 & & & & & & & \\
& & & & & & & \\
1 & 24 & 0452 & $1770.0-1774.0$ & $0.0-4.0$ & 4.0 & 3.7 & 93 \\
2 & 24 & 0552 & $1774.0-1783.5$ & $4.0-13.5$ & 9.5 & $9.5+$ & $100+$ \\
3 & 24 & 0644 & $1783.5-1793.0$ & $13.5-23.0$ & 9.5 & $9.5+$ & $100+$ \\
4 & 24 & 0752 & $1793.0-1802.5$ & $23.0-32.5$ & 9.5 & 6.1 & 64 \\
5 & 24 & 0843 & $1802.5-1812.0$ & $32.5-42.0$ & 9.5 & 7.3 & 77 \\
Totals & & & & & 42.0 & 36.1 & 86
\end{tabular}

Hole 369A

\begin{tabular}{|c|c|c|c|c|c|c|c|}
\hline 1 & 24 & 1126 & $1812.0-1821.5$ & $42.0-51.5$ & 9.5 & 9.0 & 95 \\
\hline 2 & 24 & 1210 & $1821.5-1831.0$ & $51.5-61.0$ & 9.5 & $9.5+$ & $100+$ \\
\hline 3 & 24 & 1255 & $1831.0-1840.5$ & $61.0-70.5$ & 9.5 & $9.5+$ & $100+$ \\
\hline 4 & 24 & 1338 & $1840.5-1850.0$ & $70.5-80.0$ & 9.5 & $9.5+$ & $100+$ \\
\hline 5 & 24 & 1420 & $1850.0-1859.5$ & $80.0-89.5$ & 9.5 & 9.4 & 99 \\
\hline 6 & 24 & 1504 & $1859.5-1869.0$ & $89.5-99.0$ & 9.5 & $9.5+$ & $100+$ \\
\hline 7 & 24 & 1554 & $1869.0-1878.5$ & $99.0-108.5$ & 9.5 & 9.5 & 100 \\
\hline 8 & 24 & 1649 & $1878.5-1888.0$ & $108.5-118.0$ & 9.5 & 9.5 & 100 \\
\hline 9 & 24 & 1744 & $1888.0-1897.5$ & $118.0-127.5$ & 9.5 & 8.6 & 91 \\
\hline 10 & 24 & 1834 & $1897.5-1907.0$ & $127.5-137.0$ & 9.5 & 8.4 & 88 \\
\hline 11 & 24 & 1921 & $1907.0-1916.5$ & $137.0-146.5$ & 9.5 & 9.3 & 98 \\
\hline 12 & 24 & 2018 & $1916.5-1926.0$ & $146.5-156.0$ & 9.5 & 9.5 & 100 \\
\hline 13 & 24 & 2059 & $1926.0-1935.5$ & $156.0-165.5$ & 9.5 & 9.5 & 100 \\
\hline 14 & 24 & 2148 & $1935.5-1945.0$ & $165.5-175.0$ & 9.5 & 8.3 & 87 \\
\hline 15 & 24 & 2237 & $1945.0-1954.5$ & $175.0-184.5$ & 9.5 & 9.5 & 100 \\
\hline 16 & 24 & 2334 & $1954.5-1964.0$ & $184.5-194.0$ & 9.5 & 0.9 & 10 \\
\hline 17 & 25 & 0030 & $1964.0-1973.5$ & $194.0-203.5$ & 9.5 & 9.1 & 96 \\
\hline 18 & 25 & 0127 & $1973.5-1983.0$ & $203.5-213.0$ & 9.5 & 8.7 & 92 \\
\hline 19 & 25 & 0213 & $1983.0-1992.5$ & $213.0-222.5$ & 9.5 & 8.3 & 87 \\
\hline 20 & 25 & 0300 & $1992.5-2002.0$ & $222.5-232.0$ & 9.5 & 8.5 & 90 \\
\hline 21 & 25 & 0346 & $2002.0-2011.5$ & $232.0-241.5$ & 9.5 & 7.9 & 83 \\
\hline 22 & 25 & 0430 & $2011.5-2021.0$ & $241.5-251.0$ & 9.5 & 9.1 & 91 \\
\hline 23 & 25 & 0510 & $2021.0-2030.5$ & $251.0-260.5$ & 9.5 & 8.9 & 94 \\
\hline 24 & 25 & 0602 & $2030.5-2040.0$ & $260.5-270.0$ & 9.5 & 8.1 & 85 \\
\hline 25 & 25 & 0647 & $2040.0-2049.5$ & $270.0-279.5$ & 9.5 & 8.0 & 84 \\
\hline 26 & 25 & 0738 & 2049.5-2059.- & $279.5-289.0$ & 9.5 & 6.7 & 71 \\
\hline 27 & 25 & 0845 & $2059.0-2068.5$ & $289.0-298.5$ & 9.5 & 8.4 & 88 \\
\hline 28 & 25 & 0925 & $2068.5-2078.0$ & $298.5-308.0$ & 9.5 & 6.3 & 66 \\
\hline 29 & 25 & 1013 & $2078.0-2087.5$ & $308.0-317.5$ & 9.5 & 7.4 & 78 \\
\hline 30 & 25 & 1104 & $2087.5-2097.0$ & $317.5-327.0$ & 9.5 & 7.5 & 79 \\
\hline 31 & 25 & 1148 & $2097.0-2106.5$ & $327.0-336.5$ & 9.5 & 7.8 & 82 \\
\hline 32 & 25 & 1309 & $2106.5-2116.0$ & $336.5-346.0$ & 9.5 & 5.5 & 58 \\
\hline 33 & 25 & 1407 & $2116.0-2125.5$ & $346.0-355.5$ & 9.5 & 5.1 & 54 \\
\hline 34 & 25 & 1507 & $2125.5-2135.0$ & $355.5-365.0$ & 9.5 & 2.5 & 26 \\
\hline 35 & 25 & 1615 & $2135.0-2144.5$ & $365.0-374.5$ & 9.5 & 6.6 & 70 \\
\hline 36 & 25 & 1720 & $2144.5-2154.0$ & $374.5-384.0$ & 9.5 & 7.3 & 77 \\
\hline 37 & 25 & 1828 & $2154.0-2163.5$ & $384.0-393.5$ & 9.5 & 8.3 & 87 \\
\hline 38 & 25 & 1923 & $2163.5-2173.0$ & $393.5-403.0$ & 9.5 & 6.7 & 71 \\
\hline 39 & 25 & 2109 & $2173.0-2182.5$ & $403.0-412.5$ & 9.5 & 4.0 & 42 \\
\hline 40 & 25 & 2218 & $2182.5-2192.0$ & $412.5-422.0$ & 9.5 & 5.1 & 54 \\
\hline 41 & 25 & 2332 & $2192.0-2201.5$ & $422.0-431.5$ & 9.5 & 5.4 & 57 \\
\hline 42 & 26 & 0109 & $2201.5-2211.0$ & $431.5-441.0$ & 9.5 & 4.6 & 48 \\
\hline 43 & 26 & 0305 & $2211.0-2220.5$ & $441.0-450.5$ & 9.5 & 5.7 & 60 \\
\hline 44 & 26 & 0443 & $2220.5-2230.0$ & $450.5-460.0$ & 9.5 & 4.1 & 43 \\
\hline 45 & 26 & 0620 & $2230.0-2239.5$ & $460.0-469.5$ & 9.5 & 5.8 & 61 \\
\hline 46 & 26 & 0824 & $2239.5-2249.0$ & $469.5-479.0$ & 9.5 & 6.5 & 68 \\
\hline 47 & 26 & 1024 & $2249.0-2258.5$ & $479.0-488.5$ & 9.5 & 7.0 & 74 \\
\hline Total & & & & & 446.5 & 350.3 & 79 \\
\hline
\end{tabular}

\section{PHYSICAL PROPERTIES}

Tabulation of physical property measurements are in Trabant (this volume).

\section{Bulk Properties}

Bulk property measurements were made for bulk density, water content (\% dry weight), void ratio, porosity and specific gravity. Rotation of the core barrel produced corkscrew-like grooves in the retrieved sediment which due to variation in core diameter rendered GRAPE useless. Consequently, no GRAPE data were obtained. Results of bulk property measurements (Figure 8) indicate a wide scatter of values about a roughly linear change with depth associated with compaction through lithologic Units 1 
TABLE 2

Lithostratigraphy at Site 369

\begin{tabular}{|c|c|c|c|}
\hline Unit & Lithology & Cores & Age \\
\hline $1 \mathrm{a}$ & Nannofossil marls & $\begin{array}{l}1 \text { through } 9 \mathrm{~A} \\
(0.0 \text { to } 127.5 \mathrm{~m})\end{array}$ & Quaternary to early Miocene \\
\hline $1 \mathrm{~b}$ & $\begin{array}{l}\text { Siliceous nanno- } \\
\text { fossil maris }\end{array}$ & $\begin{array}{l}10 \mathrm{~A} \text { through } 33 \mathrm{~A} \\
(127.5 \text { to } 346.0 \mathrm{~m})\end{array}$ & Early Miocene to late Eocene \\
\hline $2 \mathrm{a}$ & $\begin{array}{l}\text { Argillaceous nanno- } \\
\text { fossil limestone } \\
\text { and chalk with } \\
\text { chert/porcellanite }\end{array}$ & $\begin{array}{l}33 \mathrm{~A} \text { through } 37 \mathrm{~A} \\
(346.0 \text { to } 393.5 \mathrm{~m})\end{array}$ & $\begin{array}{l}\text { Middle Eocene to late } \\
\text { Campanian to early } \\
\text { Maestrichtian }\end{array}$ \\
\hline $2 \mathrm{~b}$ & $\begin{array}{l}\text { Argillaceous marls } \\
\text { and chalks }\end{array}$ & $\begin{array}{l}38 \mathrm{~A} \text { through } 40 \mathrm{~A} \\
(393.5 \text { to } 422.0 \mathrm{~m})\end{array}$ & $\begin{array}{l}\text { Late Campanian/early } \\
\text { Maestrichtian to Coniacian/ } \\
\text { Santonian }\end{array}$ \\
\hline 3 & $\begin{array}{l}\text { Silty nannofossil } \\
\text { marls }\end{array}$ & $\begin{array}{l}41 \mathrm{~A} \text { through } 47 \mathrm{~A} \\
(422.0 \text { to } 488.5 \mathrm{~m})\end{array}$ & Albian to upper Aptian \\
\hline
\end{tabular}

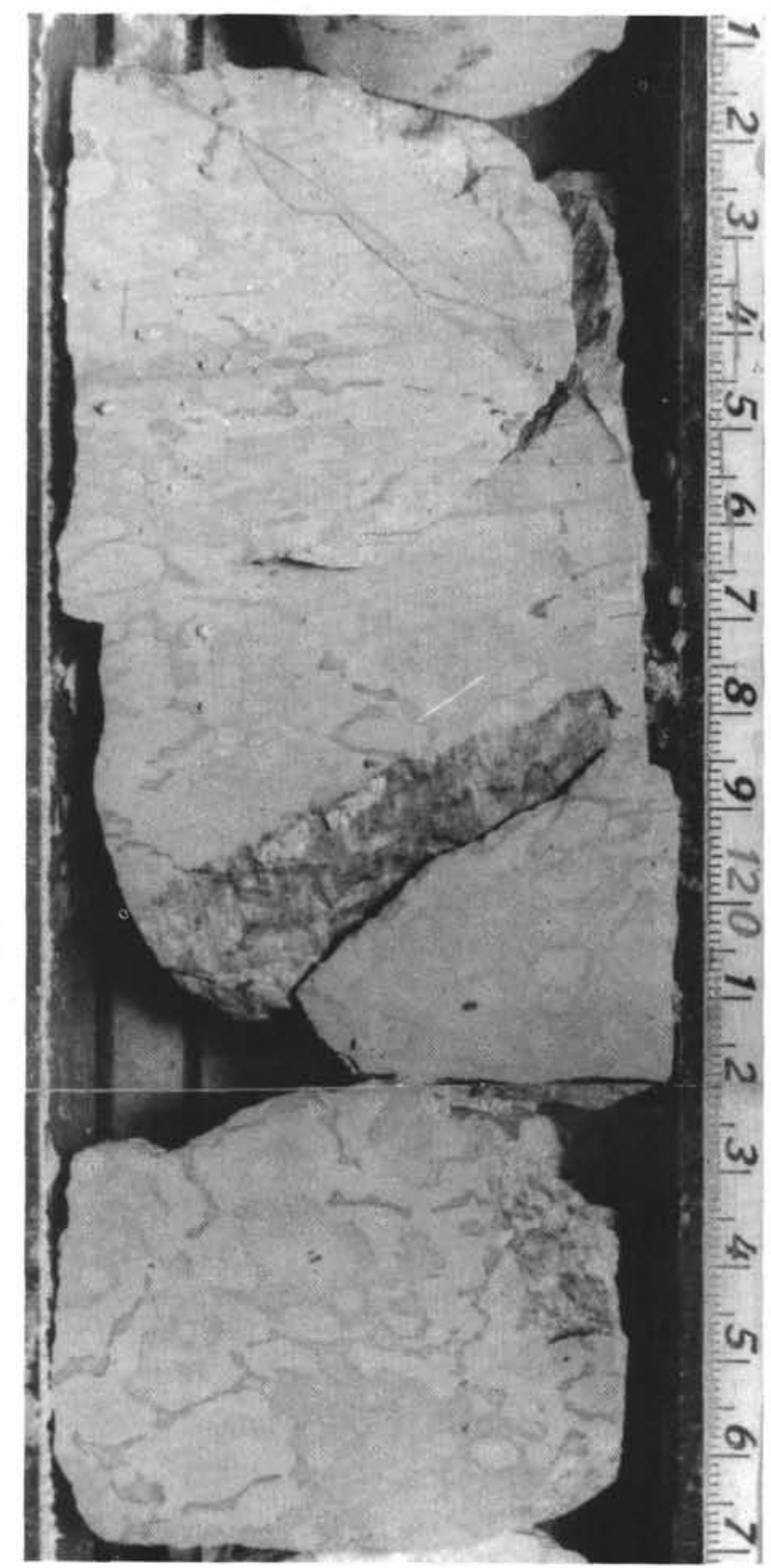

Figure 5. Ameboid-shaped mottles from Sample 41$369 \mathrm{~A}-39-2,120-125 \mathrm{~cm}$ which are typical of lithologic Subunit $2 b$.
TABLE 3

Carbon and Nitrogen Analyses for Site 369

\begin{tabular}{|c|c|c|c|c|c|c|}
\hline \multirow{2}{*}{$\begin{array}{c}\text { Sample } \\
\text { (Interval in cm) }\end{array}$} & \multirow{2}{*}{$\begin{array}{l}\text { Depth } \\
\text { (m) }\end{array}$} & \multicolumn{2}{|c|}{$\begin{array}{c}\text { \% Organic C } \\
\text { (Total dry wt. basis) }\end{array}$} & \multicolumn{2}{|c|}{$\begin{array}{c}\mathrm{C} / \mathrm{N} \\
\text { (atomic ratio) }\end{array}$} & \multirow[b]{2}{*}{ Remarks } \\
\hline & & $\mathrm{x}$ & SD & $\mathrm{x}$ & SD & \\
\hline \multicolumn{7}{|l|}{ Hole 369} \\
\hline $2-5,130$ & 11 & 0.418 & 0.007 & 7.4 & 0.13 & OG-sample \\
\hline \multicolumn{7}{|l|}{ Hole 369A } \\
\hline $2-5,130$ & 58 & 0.271 & 0.026 & 6.7 & 0.61 & OG-sample \\
\hline $4-5,76-77$ & 78 & 0.174 & 0.013 & 4.0 & 0.79 & \\
\hline $7-5,130$ & 106 & 0.177 & 0.013 & 6.8 & 0.65 & OG-sample \\
\hline $7=3,15-16$ & 103 & 1.069 & 0.012 & 10.9 & 0.57 & \\
\hline $9-6,14-15$ & 125 & 2.475 & 0.007 & 14.4 & 0.77 & \\
\hline $12-3,130-131$ & 150 & 5.280 & - & 35.7 & - & TAMU \\
\hline $12-3,130-131$ & 198 & 1.480 & - & 52.1 & - & TAMU \\
\hline $27-6,130-131$ & 297 & 1.560 & - & 10.4 & - & TAMU \\
\hline $32-3,130-131$ & 340 & 1.760 & - & 38.7 & - & TAMU \\
\hline $38-4,130-131$ & 400 & 3.03 & - & ND & - & TAMU \\
\hline $43-2,139-142$ & 450 & 2.30 & - & - & - & Leco-Shell \\
\hline
\end{tabular}

and 2 down to 425 meters within the late Albian. The porosity is reduced to less than $20 \%$ below 425 meters, within Unit 3. Several other lithologic contacts can be correlated with small changes in the bulk properties and are discussed in Trabant (this volume).

\section{Shear Strengths}

Shear strength measurements made on sediments from Site 369 indicate the possible removal of up to 300 meters of sediment above the Pliocene boundary at a depth of 40 meters. Shear strength values (Figure 9) range from 0.2 to $0.7 \mathrm{~kg} / \mathrm{cm}^{2}$ within the upper 40 meters. Below 40 meters, however, the measured values abruptly increase to well over $3.0 \mathrm{~kg} / \mathrm{cm}^{2}$. Aside from the change in shear strengths, no measured or observed parameters indicate any variations within this zone. The abrupt increase in shear strengths indicates the possible removal of overburden prior to the onset of Pliocene sedimentation. Sediments below 135 meters become too compact for shear strength measurements (over $5.0 \mathrm{~kg} / \mathrm{cm}^{2}$ ).

\section{Acoustic Velocities}

Primary wave velocities were obtained on split cores and cut subsamples using the Hamilton Frame velocimeter. The results (Figure 10) show a linear increase from $1.58 \mathrm{~km} / \mathrm{sec}$ to $2.1 \mathrm{~km} / \mathrm{sec}$ with depth. Most sediments were relatively "loose" with an occasional thin (few decimeters), high-velocity zone. The porcellanite at 358 meters with a velocity of 3.94 $\mathrm{km} / \mathrm{sec}$ is therefore atypical. Numerous values were obtained within the slump feature at a depth of 300 meters. These values range between 1.75 and 1.88 $\mathrm{km} / \mathrm{sec}$.

\section{Summary}

Few anomalies in the physical properties are evident, aside from the shear strength anomaly at 40 meters depth which suggests the possible removal of up to 300 meters of overburden.

\section{BIOSTRATIGRAPHIC SUMMARY}

The fossil assemblages of Site 369 range in age from Quaternary to upper Aptian. The calcareous microfossils provided reliable age control throughout the 
TABLE 4

Interstitial Gas Analy ses for Site 369, Leg 41

\begin{tabular}{|c|c|c|c|c|c|c|c|c|}
\hline \multirow[t]{2}{*}{$\begin{array}{c}\text { Sample } \\
\text { (Interval in } \mathrm{cm} \text { ) }\end{array}$} & \multirow[t]{2}{*}{$\begin{array}{l}\text { Depth } \\
\text { (m) }\end{array}$} & $\mathrm{N}_{2}+\mathrm{O}_{2}$ & $\mathrm{CH}_{4}$ & $\mathrm{CO}_{2}$ & $\begin{array}{l}\mathrm{C}_{2} \mathrm{H}_{6} \\
\text { (Carle) }\end{array}$ & $\begin{array}{c}\mathrm{C}_{2} \mathrm{H}_{6} \\
\text { (Bendix) }\end{array}$ & $\mathrm{C}_{3} \mathrm{H}_{8}$ & $\begin{array}{c}\mathrm{M} \\
\mathrm{E}+\mathrm{P}\end{array}$ \\
\hline & & \multicolumn{3}{|c|}{$\%$ of Total } & \multicolumn{3}{|c|}{ ppm of Total Gas } & \\
\hline $3-6,0$ & 70 & 98.6 & 0.0 & 1.4 & 0 & 0 & 0 & - \\
\hline $23-6,0$ & 260 & 20.6 & 75.3 & 4.1 & 168 & $\operatorname{Tr}$ & 0 & 4500 \\
\hline $24-4,0$ & 270 & 10.8 & 8.3 & 0.7 & 0 & 0 & 0 & - \\
\hline $25-3,0$ & 280 & 38.7 & 60.6 & 0.7 & 0 & 0 & 0 & - \\
\hline $26-3,0$ & 289 & 32.2 & 67.6 & 0.3 & 0 & 0 & 0 & - \\
\hline $27-2,0$ & 299 & 31.0 & 63.6 & 5.3 & 224 & 104 & 113 & 2900 \\
\hline $28-3,0$ & 308 & 50.8 & 44.9 & 4.2 & 0 & 0 & 0 & - \\
\hline $29-2,0$ & 318 & 56.5 & 43.4 & 0.1 & 0 & $\mathrm{x}$ & $\mathrm{x}$ & - \\
\hline $30-3,0$ & 327 & 64.9 & 33.0 & 2.1 & 0 & $\mathrm{x}$ & $\mathrm{x}$ & - \\
\hline $31-6,50$ & 337 & 35.0 & 62.2 & 2.7 & 0 & $\mathrm{x}$ & $\mathrm{x}$ & - \\
\hline $33-4,30$ & 356 & 37.5 & 59.5 & 3.0 & 0 & $\mathrm{x}$ & $\mathrm{x}$ & - \\
\hline $40-4,75 \mathrm{can}$ & 422 & 23.2 & 76.1 & 0.7 & 198 & $\mathrm{x}$ & $\mathrm{x}$ & 3800 \\
\hline $41-3,50$ can & 432 & 16.3 & 82.5 & 1.1 & 390 & $\mathrm{x}$ & $\mathrm{x}$ & 2100 \\
\hline $42-3,75$ can & 441 & 25.7 & 73.5 & 0.8 & 470 & $\mathrm{x}$ & $\mathrm{x}$ & 1600 \\
\hline $43-3,75$ & 450 & 12.4 & 86.5 & 0.9 & 1062 & 847 & 176 & 840 \\
\hline $43-3,75$ can & 450 & 14.5 & 84.6 & 0.8 & 887 & 954 & $\mathrm{Tr}$ & 890 \\
\hline $44-2,60$ & 460 & 34.9 & 64.3 & 0.7 & 509 & 319 & 0 & 1230 \\
\hline $44-2,60 \mathrm{can}$ & 460 & 30.0 & 69.2 & 0.7 & 410 & 468 & 0 & 1480 \\
\hline $45-2,0$ & 470 & 21.1 & 79.0 & 0.5 & 1100 & 840 & 182 & 720 \\
\hline $46-4,0$ & 479 & 26.0 & 73.2 & 0.6 & 740 & 587 & 189 & 940 \\
\hline $46-5,0$ & 479 & 19.6 & 79.8 & 0.5 & 1193 & 1022 & 299 & 640 \\
\hline $47-5,100$ & 489 & 21.7 & 77.7 & 0.5 & 1260 & 899 & 280 & 670 \\
\hline
\end{tabular}

Note: $\mathrm{x}$ - Bendix GC inoperative.

cored interval. Preservation of calcareous microfossils is generally good, with very few exceptions. Preservation of siliceous microfossils is moderate to good in the Oligocene to middle Miocene and in the Campanian to Maestrichtian, but poor in the remaining intervals.

Nannofossils and radiolarians suggest a higher latitude biogeographic province than those from Site 366 on the Sierra Leone Rise, perhaps subtropical instead of tropical.

\section{Foraminifers}

Planktonic and benthic foraminifers are found in sediments ranging in age from Holocene to Aptian.

\section{Cenozoic}

Core 1 contains an abundant, well-preserved Quaternary foraminifer fauna of the Globorotalia truncatulinoides Zone. Good preservation of fragile agglutinated benthic foraminifers suggests a Holocene age, although the zonal marker was not detected. Very rich lower Pliocene assemblages of planktonic foraminifers occur in Cores 1 and 2 which correlate with the Globorotalia margaritae evoluta Zone. The presence of Globorotalia aff. tumida tumida in core catcher 2 may indicate the transition to the underlying $G$. margaritae margaritae Zone. Planktonic foraminifers of lower Pliocene to upper Miocene age are abundant and mostly well preserved in Cores 3 through 5. The assemblage is typical of the $G$. margaritae margaritae Zone. The two topmost cores of Hole 369A contain mixed assemblages of middle and upper Miocene and Pliocene foraminifers probably because of coring contamination. The sediments of Cores $3 \mathrm{~A}$ to $6 \mathrm{~A}$ furnish abundant middle Miocene planktonic foraminifers which allow the following zonation: Globorotalia fohsi fohsi Zone (Core 3), Globo- rotalia perpheroacuta Zone (Core 4 and Core 5, Section 3) and Orbulina suturalis/Globorotalia peripheroronda Zone (Cores 5, Sections 4, and Core 6). Within Cores 7A through 11A, Section 6, lower Miocene faunas belong to the Praeorbulina glomerosa Zone. Benthic foraminifers are generally few and shelf species were not detected. The generic composition is very diverse. Within the lower Miocene there is a hiatus which corresponds to the Globigerinella insueta/Globigerinoides trilobus Zone. The lower part of the lower Miocene sediments contains comparatively poor assemblages of planktonic foraminifers. However, they can be correlated with the Globigerinita stainforthi, Globigerinita dissimilis, and Globigerinoides primordius/Globorotalia kugleri zones.

Almost all samples of the Oligocene interval (Cores $14 \mathrm{~A}$ through $32 \mathrm{~A}$, Section 4 ) yield good assemblages of planktonic foraminifers. The following zones are identified: Cores $14 \mathrm{~A}$ and $15 \mathrm{~A}$, the Globigerina ciperoensis Zone; Cores 16A through 24A, Section 3, the Globorotalia opima opima Zone; Cores 24A, Section 4 through $26 \mathrm{~A}$ the Globigerina ampliaperatura Zone; Core $27 \mathrm{~A}$ contains a microfauna transitional to the underlying zone; Cores $28 \mathrm{~A}$ through $29 \mathrm{~A}$, Section 2, are attributed to the Globigerina selli Zone, and Core $29 \mathrm{~A}$, Section 3 through Core 32A, Section 4, the Globigerina tapuriensis Zone.

Upper Eocene faunas were found in Sample 32A, CC through Core $33 \mathrm{~A}$, Section 4 , which belong to the uppermost part of the Globorotalia centralis/Globigerina gortanii Zone. Planktonic foraminifers are common and moderately preserved. Rare specimens of Globigerina ampliapertura indicate the upper part of this zone is transitional into the Oligocene. Rich assemblages of benthic foraminifers are found in the Oligocene and lower Miocene sediments. 
TABLE 5

$\% \mathrm{CaCO}_{3}$-Carbonate Bomb Method for Site 369

\begin{tabular}{cccc}
\hline $\begin{array}{c}\text { Sample } \\
\text { Interval in cm) }\end{array}$ & $\begin{array}{c}\text { Depth } \\
(\mathrm{m})\end{array}$ & $\% \mathrm{CaCO}_{3}$ & Lithology \\
\hline
\end{tabular}

Hole 369

$\begin{array}{llll}4-5,84-85 & 35 & 43 & \text { Nanno marl } \\ 5-4,121-122 & 38 & 61 & \text { Clayey nanno marl }\end{array}$

Hole 369A

\begin{tabular}{|c|c|c|c|}
\hline $1-3,76-77$ & 46 & 58 & Clayey nanno marl \\
\hline $2-3,57-58$ & 56 & 61 & Clayey nanno marl \\
\hline $3-3,36-37$ & 65 & 61 & Nanno marl \\
\hline $4-3,87-89$ & 75 & 61 & Nanno ooze \\
\hline $5-3,56-57$ & 84 & 51 & Nanno marl \\
\hline $6-3,123-124$ & 94 & 44 & Nanno marl \\
\hline $6-6,30-31$ & 98 & 56 & Nanno marl \\
\hline $7-3,34-35$ & 103 & 49 & Nanno marl \\
\hline $8-3,99-100$ & 113 & 30 & Nanno marl \\
\hline $9-1,147-149$ & 120 & 26 & Nanno clay \\
\hline $10-3,56-57$ & 131 & 31 & Nanno marl \\
\hline $11-3,95-96$ & 141 & 30 & Nanno diatom marl \\
\hline $12-3,77-78$ & 151 & 14 & Nanno diatom marl \\
\hline $13-3,82-83$ & 160 & 17 & Nanno diatom clay \\
\hline $15-3,79-80$ & 179 & 28 & Nanno marl \\
\hline $17-3,89-90$ & 198 & 20 & Nanno diatom clay \\
\hline $18-3,74-75$ & 208 & 29 & Nanno diatom marl \\
\hline $19-3,73-74$ & 217 & 28 & Nanno marl \\
\hline $20-3,114-115$ & 227 & 44 & Nanno marl \\
\hline $21-3,34-35$ & 235 & 36 & Nanno marl \\
\hline $22-3,81-82$ & 245 & 40 & Nanno marl \\
\hline $23-2,104-105$ & 255 & 41 & Nanno marl \\
\hline $24-3,109-110$ & 265 & 9 & Nanno marl \\
\hline $25-3,94-95$ & 274 & 43 & Nanno marl \\
\hline $26-3,54-55$ & 283 & 18 & Nanno marl \\
\hline $28-3,83-84$ & 302 & 36 & Nanno marl \\
\hline $29-3,56-57$ & 312 & 35 & Nanno marl \\
\hline $31-3,80-82$ & 321 & 24 & Nanno clay \\
\hline $32-1,72-73$ & 337 & 28 & Silty nanno marl \\
\hline $33-3,68-69$ & 350 & 37 & Nanno marl \\
\hline $33-4,135-136$ & 351 & 71 & Argillaceous limestone \\
\hline $34-2,131-132$ & 358 & 55 & Argillaceous limestone \\
\hline $35-2,98-99$ & 368 & 79 & Argillaceous limestone \\
\hline $36-3,90-91$ & 378 & 73 & Argillaceous limestone \\
\hline $37-3,104-110$ & 388 & 51 & Nanno marlstone \\
\hline $37-6,10-11$ & 391 & 43 & Nanno marlstone \\
\hline $37-6,23-24$ & 391 & 51 & Nanno marlstone \\
\hline $38-2,44-45$ & 395 & 40 & Nanno-bearing marl \\
\hline $38-3,127-128$ & 398 & 51 & Nanno-bearing marl \\
\hline $39-3,48-50$ & 407 & 76 & Argillaceous chalk \\
\hline
\end{tabular}

Quantitatively, the benthic foraminifers remain minor as compared to the planktonic foraminifers. The sequence in Core 33A, Section 4 , to Core $35 \mathrm{~A}$, Section 5, falls within the Globorotalia lehneri Zone of the middle Eocene. Benthic foraminifers are very rare.

\section{Mesozoic}

Two zones were identified within the Maestrichtian: Core 35A contains the Abathomphalus mayaroensis Zone and the Globotruncana gansseri Zone was found in Core 36A. Core catchers $37 \mathrm{~A}$ and $38 \mathrm{~A}$ fall somewhere within the lower Maestrichtian to upper Campanian. The Campanian stage is represented in Cores 39A by its lower part, the Globotruncana elevata Zone. Planktonic foraminfers are abundant but of low specific diversity in core catcher $40 \mathrm{~A}$. The age of these sediments range from Coniacian to Santonian. Benthic foraminifers are usually rare to few. Core catcher $41 \mathrm{~A}$

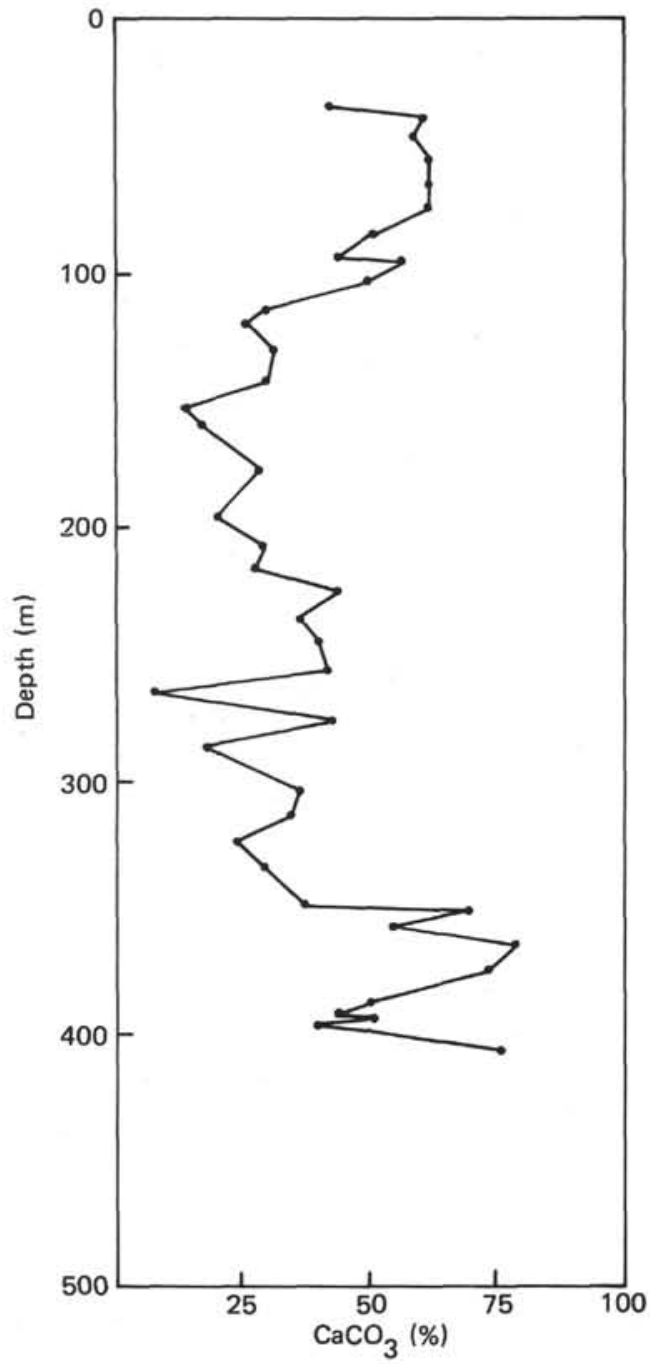

Figure 6. Plot of percent carbonate versus depth for Site 369.

is assigned to the lower part of the Albian stage. Core catcher $42 \mathrm{~A}$ is attributed to the Rotalipora subticinensis Zone and core catcher 43A corresponds to the Ticinella roberti Zone. Core catcher $44 \mathrm{~A}$ is considered as uppermost Aptian to lowermost Albian. Cores 45A through 47A contain Aptian-aged assemblages. Benthic foraminifers of Aptian and Albian age are very rare in the olive-black marls. The abundance of planktonic foraminifers, their good preservation, and their strong predominance over benthic foraminifers indicate pelagic, bathyal conditions of sedimentation throughout the upper Aptian to Pleistocene. The foraminiferal faunas of the Aptian to Albian black shale facies differ from the faunas of similar sediments recovered from Sites 367 and 368. The planktonic foraminiferal fauna at Site 369 is more diverse with tests of normal dimensions.

\section{Calcareous Nannoplankton}

Preservation of coccoliths is generally moderate to good and the specimens are common to abundant. The following nine biostratigraphic intervals were identified: (1) The Pleistocene (Core 1, Section 1); Miocene 
TABLE 6

Summary of Interstitial Water Analyses for Site 369

\begin{tabular}{|c|c|c|c|c|c|c|c|}
\hline $\begin{array}{c}\text { Sample } \\
\text { (Interval in } \mathrm{cm} \text { ) }\end{array}$ & $\begin{array}{c}\text { Depth } \\
\text { (m) }\end{array}$ & $p \mathrm{H}$ & $\begin{array}{l}\text { Alkalinity } \\
(\mathrm{meq} / \mathrm{kg})\end{array}$ & $\begin{array}{c}\text { Salinity } \\
\left.(\%)_{0}\right)\end{array}$ & $\underset{(\mathrm{mmoles} / \mathrm{l})}{\mathrm{Ca}^{++}}$ & $\underset{(\mathrm{mmoles} / \mathrm{l})}{\mathrm{Mg}^{++}}$ & $\begin{array}{c}\mathrm{Cl}^{-} \\
(\%)\end{array}$ \\
\hline \multicolumn{8}{|l|}{ Hole 369} \\
\hline $1-2,144-150$ & 3.0 & 7.39 & 2.64 & 35.2 & 10.60 & 53.14 & 19.48 \\
\hline $5-4,144-150$ & 37.5 & 7.11 & 6.01 & 35.5 & 13.04 & 48.66 & 20.77 \\
\hline \multicolumn{8}{|l|}{ Hole 369A } \\
\hline $5-5,144-150$ & 87.5 & 7.02 & 6.69 & 36.2 & 15.60 & 39.60 & 20.77 \\
\hline $10-5,144-150$ & 135.0 & 6.91 & 9.36 & 36.8 & 14.88 & 38.13 & 21.97 \\
\hline $14-5,144-150$ & 163.0 & 6.83 & 9.74 & 37.3 & 16.62 & 37.85 & 22.47 \\
\hline $20-5,144-150$ & 230.0 & 6.78 & 8.50 & 39.0 & 20.35 & 38.06 & 23.64 \\
\hline $25-5,144-150$ & 277.5 & 7.12 & 6.35 & 39.9 & 20.90 & 38.09 & 23.87 \\
\hline $30-4,144-150$ & 323.5 & 6.80 & - & 40.7 & 22.74 & 39.03 & 24.90 \\
\hline $31-5,144-150$ & 334.5 & 6.75 & 6.34 & 41.2 & 23.98 & 39.39 & 25.17 \\
\hline $35-3,144-150$ & 369.5 & 6.80 & 5.62 & 43.4 & 25.92 & 41.54 & 26.97 \\
\hline $40-2,144-150$ & 415.5 & 6.86 & 4.14 & 46.2 & 28.11 & 43.87 & 28.70 \\
\hline $44-1,144-150$ & 452.0 & 6.94 & 3.40 & 46.3 & 28.96 & 44.34 & 28.03 \\
\hline
\end{tabular}

(Cores 1 to 5, 1A through 12A); Oligocene (Cores 14A through 32A); Eocene (Cores $33 \mathrm{~A}$ to $35 \mathrm{~A}$ ); Maestrichtian (Cores 35A through 37A): Campanian (Core 39A, CC); Coniacian to Santonian (Core 40A, CC); upper Albian to Turonian (Core 41, CC); and upper Aptian to lower Albian (Cores 42A through 47A).

\section{Cenozoic}

Pleistocene sediments were recovered only in Core 1 at a depth of $141-142 \mathrm{~cm}$ in Section 1. The assemblage is rich and well preserved and belongs to the Emiliania huxleyi Zone. Limited reworking was observed. Miocene sediments in Cores 1 to 5 and $1 \mathrm{~A}$ to $12 \mathrm{~A}$ can be divided into several zones. The upper Miocene is represented by the Discoaster neohamatus and Discoaster quinqueramus zones. The Discoaster hamatus Zone occurs in Sample 5, CC. The assemblages of coccoliths are abundant and well preserved. Only discoasters show partial overgrowths. The Sphenolithus heteromorphus Zone of late early or early middle Miocene age was identified in Cores $4 \mathrm{~A}$ to $10 \mathrm{~A}$. Tropical Discoaster signus is common through the zone. The coccoliths are abundant and well preserved. The floras of Cores $10 \mathrm{~A}$ through $12 \mathrm{~A}$ belong to the lower Miocene. In Cores $10 \mathrm{~A}$ and $11 \mathrm{~A}$ the Helicopontosphaera ampliaperta Zone is present and in Cores $11 \mathrm{~A}$ and $12 \mathrm{~A}$ the Triquetrorhabdulus carinatus Zone is found. The coccoliths of lower Miocene age are generally common although they are rare at some level, and poorly to moderately preserved owing to dissolution. Core 13A contains low diversity assemblages of the Triquetrorhabdulus carinatus Zone. The coccoliths are few to common with evidence of strong dissolution and poor preservation. The boundary within the core is not determined. Oligocene coccoliths were recognized in Cores 14A through 32A. The top of the Oligocene (Cores 14A to 20A) correlates with the Sphenolithus ciperoensis Zone. Below this level, in Cores 20A through 24A, coccoliths indicate the Sphenolithus distentus Zone. This zone is upper middle Oligocene or lower upper Oligocene, according to various authors. Lower Oligocene assemblages from the Sphenolithus predistentus Zone are found in Sample
24A, CC through Core 27A. Coccolithus formosus without Eocene discoasters was recognized in Sample $30 \mathrm{~A}, \mathrm{CC}$ through Section $32 \mathrm{~A}-4$. This helps identify the lower Oligocene Coccolithus formosus Subzone. Coccoliths are poorly to moderately preserved and are rare to common in the upper Oligocene. In other parts of the Oligocene, coccoliths are common to abundant with moderate to good preservation. The highest occurrence of rare Discoaster saipanensis and common Isthmolithus recurvus in Core 33A approximates the top of the Eocene. Discoaster saipanensis, which has a range from the upper part of middle Eocene to upper Eocene, was identified in Core 33A, Section 4. The flora in lower Cores $33 \mathrm{~A}$ to $35 \mathrm{~A}$ correlates with the middle Eocene Discoaster bifax Subzone.

\section{Mesozoic}

Cretaceous assemblages of nannofossils were found in Sample 35A, CC and Cores 36A through $47 \mathrm{~A}$. In order to establish a better correlation of the Upper Cretaceous sediments, we used the same zonation as was used on Leg 39 and on Leg 40 . We followed the zones of Thierstein (1976). The zonation from Thierstein $(1971,1973)$ was used for the Lower Cretaceous. Floras which belong to the late Maestrichtian (Micula mura Zone) were observed in Samples $35 \mathrm{~A}, \mathrm{CC}$ to $36 \mathrm{~A}-3,20-21 \mathrm{~cm}$. Core catcher $36 \mathrm{~A}$ to Core $38 \mathrm{~A}$, Section $3,60-61 \mathrm{~cm}$ belong to the Lithraphidites quadratus Zone, but Micula mura and Tetralithus trifidus were not found. The Maestrichtian coccoliths are abundant and moderate to well preserved. No significant reworking was observed. The Tetralithus trifidus Zone was found in Sample 38A, CC, which includes the late Campanian and early Maestrichtian. Eiffellithus eximius was recognized in Sample 39A, CC which defines the upper limit of the Eiffellithus eximius Zone, and Broinsonia parca, which defines the base of this zone. This zone includes lower and middle parts of the Campanian. The coccoliths are abundant with moderate preservation. Core catcher $40 \mathrm{~A}$ contains farily well preserved coccoliths which belong to the Marthasterites furcatus Zone. There is a large change in the abundance, preservation, and 

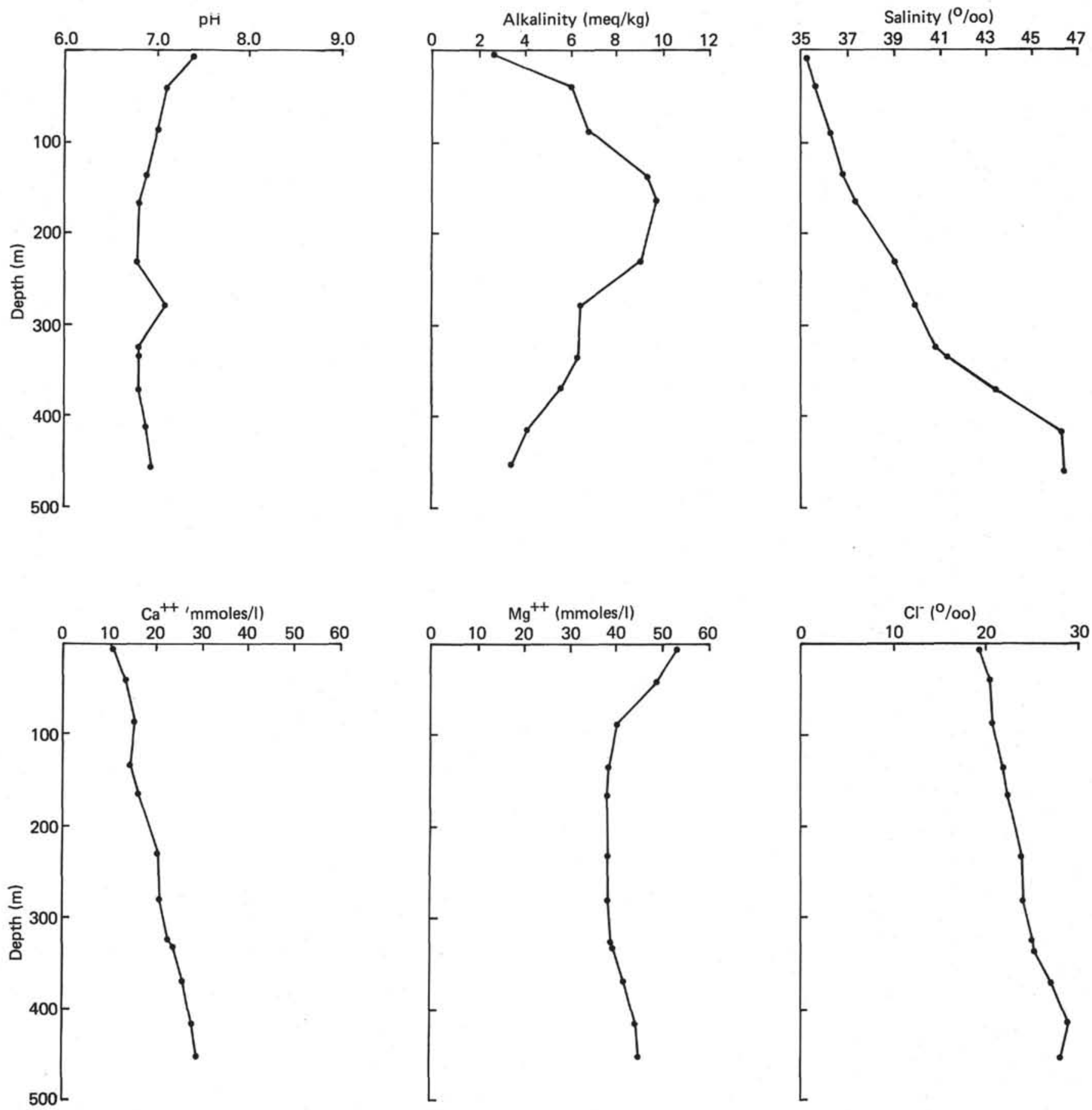

Figure 7. Plots of interstitial water analyses for Site 369.

content of the coccoliths in Samples 41A, CC and 42-2, $80-81 \mathrm{~cm}$. The coccoliths become rare with moderate preservation. The assemblage is not older than the Eiffellithus turrisieffeli Zone; the last zone of the Lower Cretaceous, because Eiffellithus turriseiffeli is present. A determination of the upper limit is difficult. We indicate Turonian as an upper limit, based on the last known occurrence of Parhabdolithus asper. The same late Aptian to early Albian coccolith assemblage was found in Sample 42A, CC and Cores 43A through 47A. The coccoliths of this interval are common to abundant and preservation is moderate to good. The presence of
Prediscosphaera cretacea and the absence of species which represent the Eiffellithus turriseiffeli Zone indicate this assemblage belongs to the Prediscosphaera cretacea Zone.

\section{Radiolarians}

Radiolarians from Site 369 are sufficiently abundant and well preserved for reliable paleontological age control within six stratigraphic intervals (Table 7). Elsewhere within the section, radiolarians are absent or are present only as poorly preserved and unidentifiable fragments. 


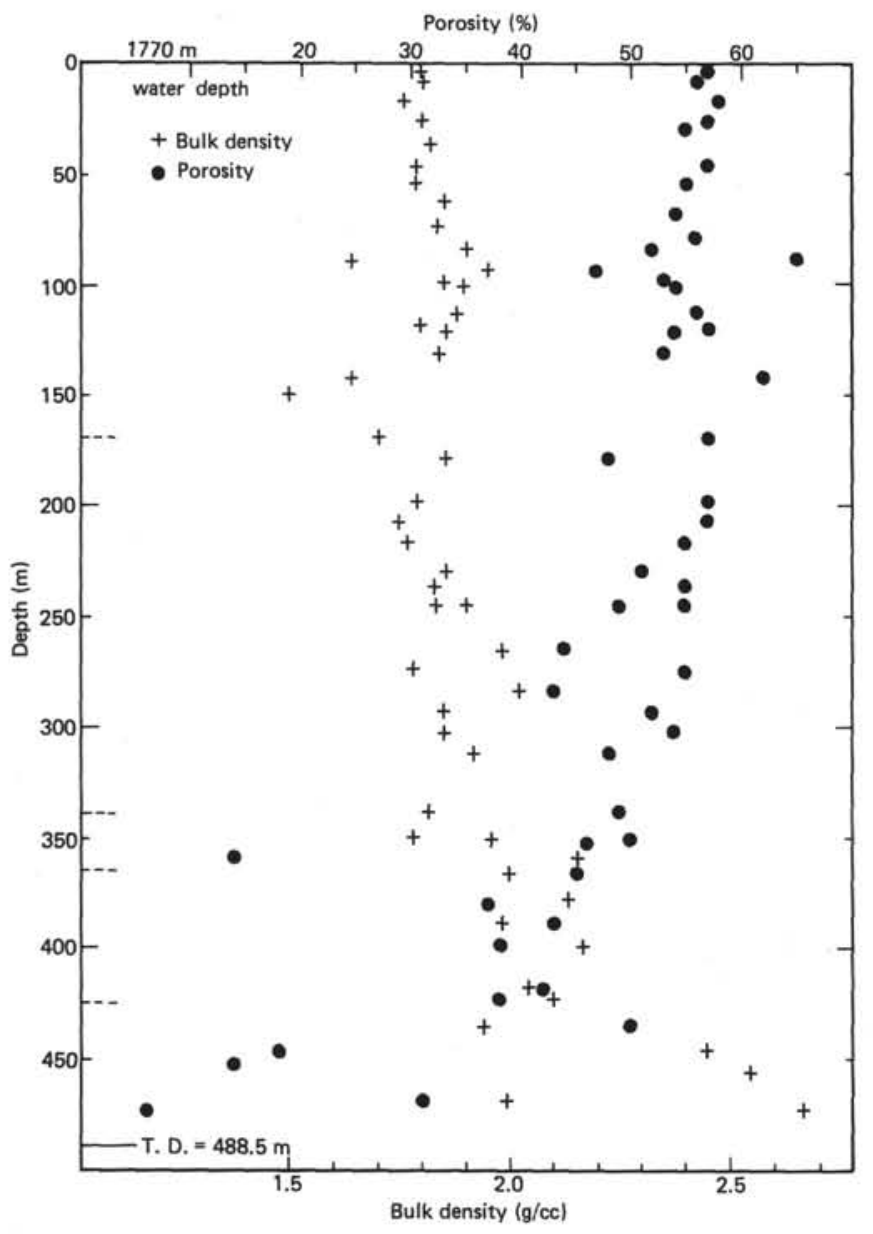

Figure 8. Plot of porosity versus depth for Site 369.

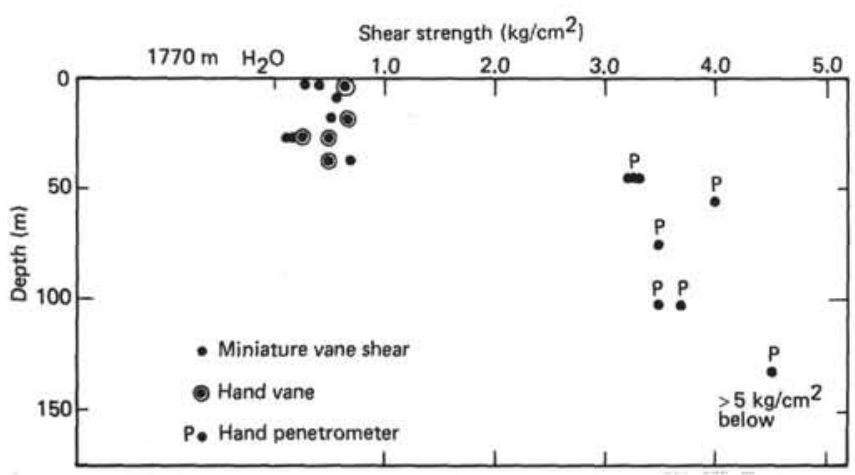

Figure 9. Plot of shear strength versus depth for Site 369.

It was generally possible to identify radiolarian zones within the biostratigraphic framework which is applicable in low latitude regions (Riedel and Sanfilippo, 1974b). However, even the samples showing very good preservation commonly lack several of the diagnostic taxa which are key stratigraphic indicators in tropical assemblages. For example, species belonging to the genus Dorcadospyris are notably rare, and the critical zonal indicator species for the upper Oligocene to lower Miocene (Lychnocanoma elongata) was not observed. Consequently, the zonal age assignments, particularly in the Oligocene and Miocene, should be regarded as tentative. Some of the uncertainty in zonal age determination may perhaps be attributed to reworking of the assemblages, a factor which may well

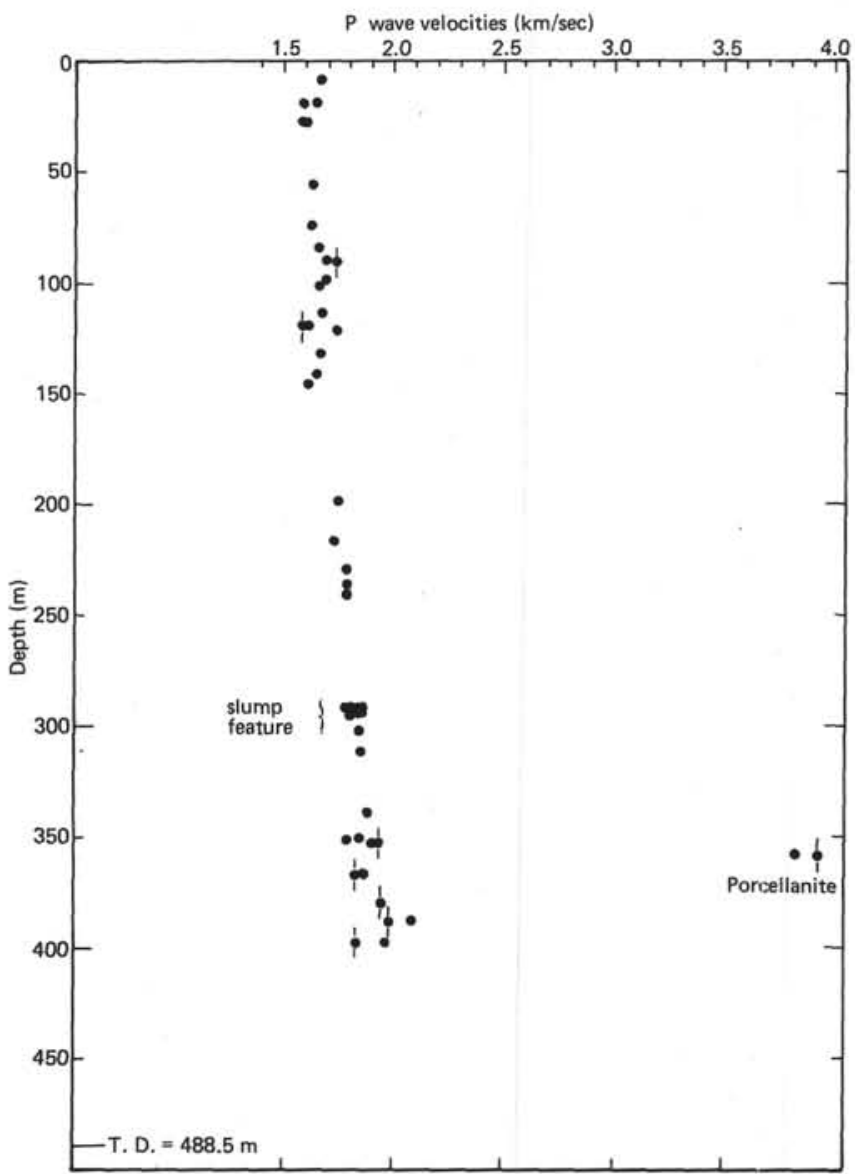

Figure 10. Plot of acoustic velocity versus depth for Site 369.

TABLE 7

Intervals in Which Radiolarians Provide Reliable Age Control

\begin{tabular}{|c|c|c|}
\hline Core & $\begin{array}{l}\text { Depth of Interval } \\
(\mathrm{m})\end{array}$ & Age \\
\hline 1 & 0.0 to 1.0 & Pleistocene \\
\hline $1 \mathrm{~A}$ to $5 \mathrm{~A}$ & 42.0 to 89.5 & Middle Miocene \\
\hline $9 \mathrm{~A}$ to $13 \mathrm{~A}$ & 127.5 to 163.5 & Middle to lower Miocene \\
\hline $13 \mathrm{~A}$ to $32 \mathrm{~A}$ & 163.5 to 346.0 & Oligocene \\
\hline $33 \mathrm{~A}$ to $35 \mathrm{~A}$ & 355.5 to 372.0 & Middle Eocene \\
\hline $35 \mathrm{~A}$ to $39 \mathrm{~A}$ & 374.5 to 412.5 & Maestrichtian to Campanian \\
\hline
\end{tabular}

be of importance in view of the physiographic setting of this site. An additional factor, however, may be the higher latitude biogeographic province of Site 369 in comparison with tropical regions. The radiolarians at Site 369 bear a very close resemblance to the Mediterranean assemblages described by Sanfilippo et al. (1973).

\section{Cenozoic}

The top of Core 1 contains rare, moderately preserved radiolarians which are consistent with a Pleistocene age. Scattered reworked Tertiary specimens are also present. Radiolarians were totally absent in the upper five cores except for this one sample. Cores 1A to $5 \mathrm{~A}$ contain diverse and well-preserved middle Miocene radiolarian assemblages of tropical to subtropical affinities. Core 1A belongs to the Cannartus petterssoni Zone. Cores $2 \mathrm{~A}$ through $5 \mathrm{~A}$ apparently represent the 
underlying Dorcadospyris alata Zone. The indicator species (Dorcadospyris alata), however, was absent from all samples except for a few specimens in Sample $4 \mathrm{~A}, \mathrm{CC}$. Consequently, there is some uncertainty in assigning a zonal age to these samples. Samples from Cores $6 \mathrm{~A}$ through $8 \mathrm{~A}$ are either devoid of radiolarians, or contain only scattered fragments. Calcareous microfossils in these cores indicate a middle Miocene age. Well-preserved radiolarians of middle to lower Miocene age are present in Sample 9A, CC through Core 13A, Section 5. These cores belong to the Dorcadospyris alata Zone. Cores 10A, Section 6, through 11A, Section 1, belong to the Calocycletta costata Zone. Cores 11A, Section 2, through 11A, Section 3, are from the Stichocorys wolffii Zone. Cores $11 \mathrm{~A}$, Section 4, through 12A, Section 3, lie within the Stichocorys delmontensis Zone. Cores 12A, Section 4, through 13A, Section 5, are from the Cyrtocapsella tetrapera Zone. The Lychnocanoma elongata Zone, of latest Oligocene and earliest Miocene age, was not definitely identified at this site because the diagnostic species (L. elongata and Calocycletta robusta) were not found. Cores 13A through 31A (and perhaps 32A) represent a relatively complete Oligocene section in which radiolarians are generally common and well preserved. However, there is some difficulty in assigning zonal names because the three species which define the zonal boundaries (L. elongata, Dorcadospyris ateuchus, Lithocyclia angustum) are very rare or missing entirely. Nevertheless, approximate age control is possible by assuming that the presence of Theocrytis annosa together with Dorcadospyris circulus is indicative of the $D$. ateuchus Zone and that the presence of Theocrytis tuberosa (exclusive of T. annosa, D. circulus, and $D$. ateuchus) indicates approximately the $T$. tuberosa Zone. Under these assumptions, tentative zonal age assignments are possible. Cores 13A through $24 \mathrm{~A}$ belong to the $D$. ateuchus Zone. Cores $25 \mathrm{~A}$ through $31 \mathrm{~A}$ are in the T. tuberosa Zone. Preservation becomes poor near the base of the Oligocene. Core 32A contains specimens of $T$. tuberosa, but is apparently of latest Eocene age, based on foraminifers. Cores $33 \mathrm{~A}$ through $35 \mathrm{~A}$, Section 5 , contain poorly preserved but identifiable fragments of radiolarians which indicate a middle Eocene age. Cores 33A, Section 2, through 34A, Section 1, are in the Polocyrtis chalara Zone and Sample 34A, CC through Core 35A, Section 5, are in the Polocyrtis mitra Zone. An unconformity is present within Core $35 \mathrm{~A}$ between the Eocene and Maestrichtian.

\section{Mesozoic}

Samples 35A, CC through 39A, CC contain white chalk of Late Cretaceous age, within which radiolarians are rare to common and of moderate to good preservation. Assignment of biostratigraphic age is possible, using the Cretaceous zonation proposed by Riedel and Sanfilippo (1974a). Cores 35A through 37A are of Maestrichtian age, within the Theocapsomma comys Zone. Cores $38 \mathrm{~A}$ and $39 \mathrm{~A}$ are of Campanian age, and consist of moderately to well preserved specimens.

Several observations are worth recording concerning the radiolarians assemblages at Site 369:
1) The Neogene record is virtually identical to that of the previous Leg 41 sites and to the sites of Leg 14; namely, no silica deposition between approximately the middle Miocene and the late Pleistocene.

2) The Oligocene and Miocene sequence at Site 369 is significantly different from that at Site 366 on the Sierra Leone Rise, reflecting perhaps a distinction between tropical and subtropical biogeographic provinces. The Site 369 radiolarian assemblages are remarkably similar to those observed in Mediterranean samples (Sanfilippo et al., 1973).

3) Diatoms are common and well preserved in the Oligocene to Miocene, and may be useful for further biostratigraphic control.

\section{Conclusions}

The following tentative interpretations can be drawn from the biostratigraphic data at Site 369:

1) We conclude that the site has been above the CCD since the Aptian because calcareous microfossils are well preserved throughout the interval cored at this site.

2) The high ratio of planktonic to benthic foraminifers throughout the section suggests a relatively open ocean environment for that period. This ratio changes somewhat, but the abundance of benthics is never very high, and there is never any record of shallow water benthic species.

3) Biogenous silica accumulation during the Cenozoic at Site 369 bears a close resemblance to the patterns observed at the other Leg 41 sites, indicating that variations in upwelling and/or primary productivity may have been regional in their geographic extent.

4) Although the site is positioned on a continental slope, a continuous sequence is present within the Neogene, the Oligocene, and part of the Upper Cretaceous. Gaps were recognized between the Pleistocene and lower Pliocene, uppermost upper Eocene and middle Eocene, middle Eocene and uppermost Maestrichtian, and between Coniacian and middle to lower Albian.

\section{ACCUMULATION RATES}

Figure 11 presents a rough overview of changing accumulation rates at Site 369. In cases of disagreement between the different absolute time scales (see Introduction, this volume), relatively broad time intervals have been used. Many of our results should be considered as preliminary because of possible disturbances by slumping, reworking, etc. No attempt has been made to correct the accumulation rates for the effects of compaction.

Only four gaps were detected in the core-catcher material even though the site is located on a continental slope. They occur between Pleistocene and lower Pliocene, between uppermost and middle Eocene, between middle Eocene and uppermost Cretaceous, and between Coniacian and middle Albian. The highest mean accumulation rates are calculated for the time intervals around the Miocene/Pliocene boundary (ca. $30 \mathrm{~m} / \mathrm{m} . \mathrm{y}$.) and within the Oligocene (ca. $20 \mathrm{~m} / \mathrm{m} . \mathrm{y}$.). These values, together with lithology, faunal composition, and continuity, suggest relatively quiet sedimenta- 


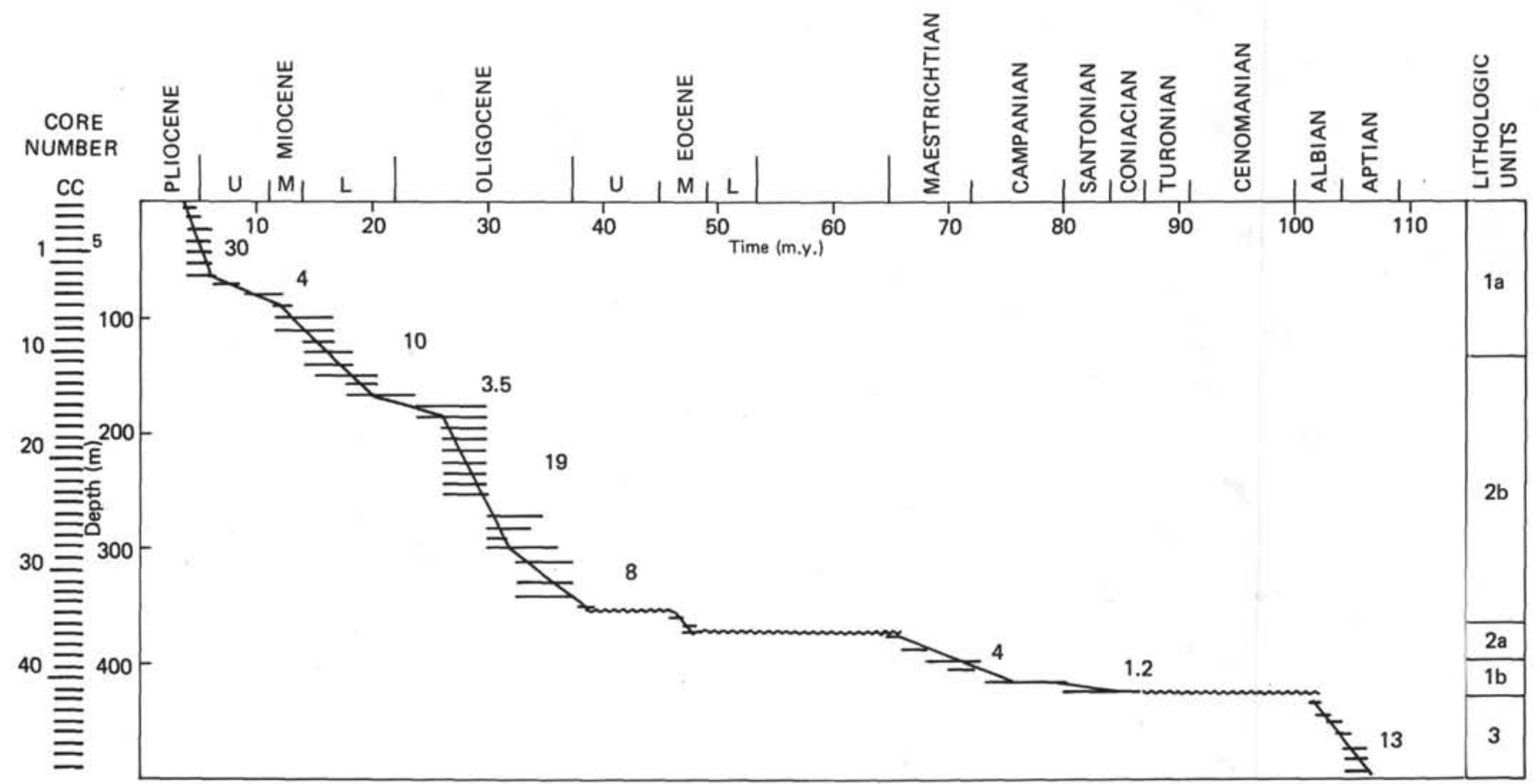

Figure 11. Plot of average accumulation rates versus time for Site 369.

tion and low terrigenous input. The accumulation rates are around 8 to $13 \mathrm{~m} / \mathrm{m}$.y. during early Miocene, early Oligocene, and Aptian to Albian. Reduced accumulation rates are calculated for the upper Miocene, around the Oligocene/Miocene boundary, and during the Upper Cretaceous (around 3 to 4 $\mathrm{m} / \mathrm{m} . \mathrm{y}$.$) .$

\section{CORRELATION OF SEISMIC REFLECTION PROFILE WITH DRILLING RESULTS}

The correlation between the seismic reflection profile and the drilling results is based on the profile recorded while approaching the site (Figure 12). Additional information from the reference profile Meteor 25/1971 (Figure 2) has been used in order to facilitate the identification and exact location of the reflectors.

A faint reflector $\left(D_{2}\right)$ is observed at about $0.14 \mathrm{sec}$ below the sea floor. It correlates well with a lithological change observed at about 125 meters, where nannofossil marl and ooze of Subunit 1A overlies siliceous nannofossil marl of Subunit 1B. This lithological change also corresponds with a noticeable change in physical properties (see Physical Properties, this chapter). This correlation implies an average interval sound velocity of about $1.78 \mathrm{~km} / \mathrm{sec}$. This value appears a little high compared to the experimental values obtained from the core samples (1.65 to 1.7 $\mathrm{km} / \mathrm{sec}$ ). Drilling disturbances, however, might account for the difference. A barely visible reflector (easier to detect on the Meteor profile) is present at 0.32 sec. It correlates well with the top (at $290 \mathrm{~m}$ ) of the slumped layers found in Cores 27 through 33, if an interval velocity of $1.8 \mathrm{~km} / \mathrm{sec}$ is assumed for the upper $0.32 \mathrm{sec}$ of the section. A third reflector $\left(D_{1}\right)$, more prominent than the previous ones, and corresponding with a slight angular unconformity on the seismic profiles, is observed at $0.32-0.40 \mathrm{sec}$. It correlates with a very abrupt change (possibly accentuated by erosion?) in lithology where relatively soft marl of Subunit 1B overlies very hard limestone of Subunit 1A. This lithological break occurs at about 350 meters below the sea floor and the inferred interval sound velocity for the overlying sediments is again about $1.8 \mathrm{~km} / \mathrm{sec}$.

\section{SUMMARY AND CONCLUSIONS}

Site 369 is only the second DSDP attempt to drill on a continental slope. During the previous attempt, Site 108 of Leg 11 (Hollister, Ewing, et al., 1972), only about $12 \mathrm{~m}$ of sediments were recovered from almost outcropping Eocene layers on the slope off Cape Hatteras. Therefore, the reasonable penetration, continuous coring, and relatively good recovery at Site 369 make the section recovered particularly representative of the continental slope sediments. This section, from top to bottom, consists of about 120 meters of nannofossil marl and ooze of Quaternary through early Miocene age, overlying about 220 meters of early Oligocene-late Eocene siliceous nannofossil marl, 60 meters of middle Eocene-Late Cretaceous argillaceous limestone and chalk with occasional chert, and about 85 meters of upper Cretaceous to late Aptian dark colored silty nannofossil marl (see Figure 13).

\section{Most Significant Results}

The most striking aspect of the nature of the sediments recovered from the continental slope is the predominance of the pelagic facies over the hemipelagic facies. The biogenous contribution to the sediments is much more important than the terrigenous one. Biogenous contribution is reflected by the carbonate content of the sediments ( $40 \%$ to $80 \%$, upper Cretaceous and Neogene). Because no detrital carbonates were observed, these values give an overall image of the minimum biogenous contribution. 


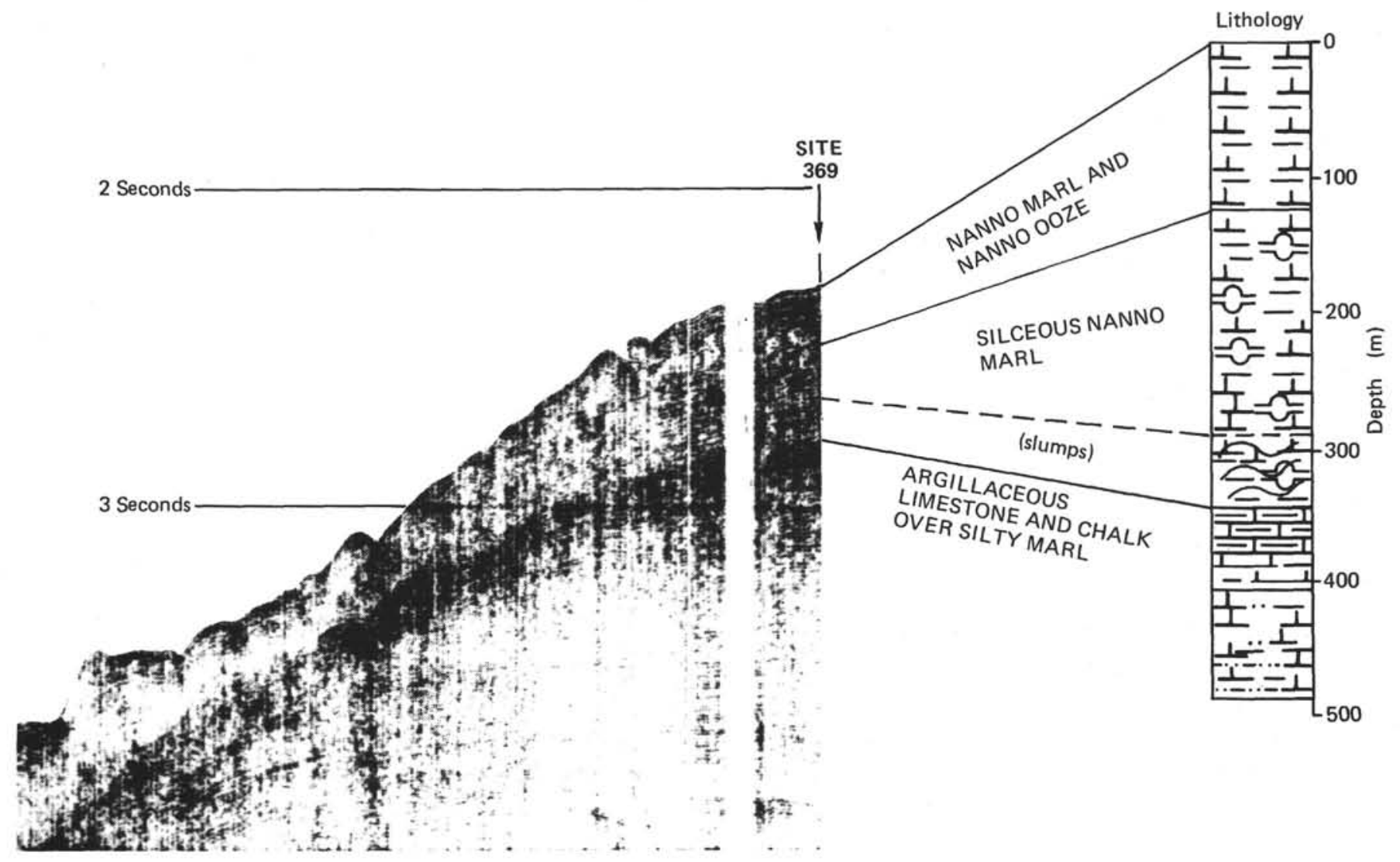

Figure 12. Correlation of seismic-reflection profile and drilling results at Site 369.

Abundant siliceous microfossils represent a substantial addition to the biogenous fraction. Therefore, roughly two-thirds of the sediment components are of biogenous origin. The rates of accumulation also reflect typical pelagic sedimentation. The terrigenous fraction is represented mainly by clay with only minor silt-generally restricted to the early Cretaceous-indicating that either the coarse material accumulated near the coast in a subsiding coastal basin or the continental slope was bypassed by the coarse detrital material which was transported into the deep basin. It is probable that most of that coarse material could eventually be brought down to the basin through submarine canyons, especially during regressions.

It is impossible to decide if the composition of the sediments recovered at Site 369 is only of regional significance or if it represents typical environmental conditions prevailing on other "passive" continental margins. The very incomplete results of Site 108, however, give indications that are in good agreement with our observations, because the only sediments recovered at that site were Eocene siliceous chalks almost devoid of terrigenous components.

The evolution of water depth is difficult to evaluate and only indirect evidence can be used, such as the absence of shallow water elements. It appears reasonable to conclude that at least since the Aptian water depths did not change drastically, and that all the sediments recovered reflect deposition on a continental slope above the CCD. No shallow water benthic foraminifers were observed and the ratio of plank- tonic/benthic foraminifers is always relatively high. The only changes observed in the microfauna seem more related to particular conditions (such as selective dissolution or changes in the environmental characteristics of the water masses) than to water depth changes. Indirect evidence, however, suggests that these conditions might not have been permanent in earlier times. The thick sediment accumulation of pre-Aptian age observed on the seismic profiles (Figure 2) indicates that shallow water facies with high rates of accumulation might be present below the level reached at Site 369. If this is the case, then most of the subsidence of the slope area could have occurred in the relatively early history of the margin (Jurassic-Early Cretaceous) instead of during the later phase of tectonism (Late Cretaceous-Oligocene) postulated by Seibold and Hinz (1974).

Slumping is only of relatively minor importance at this site and the pelagic nature of the sediments indicates that the slope is characterized more by slow sediment upbuilding than by massive removal and erosion. The stratigraphy, although based on very preliminary observations, shows a relatively continuous record. The accumulation rates in general reflect this type of pelagic deposition and apart from three hiatuses the values are typical of accumulations found on rises with only minor terrigenous contribution. Hiatuses were found in the late Pliocene, where there is a gap of about 3 m.y.; early late Eocene ( 7 m.y.); early EocenePaleocene ( $\sim 17$ m.y.); and Turonian-late Albian ( 16 m.y.). None of these hiatuses are particularly large, but 


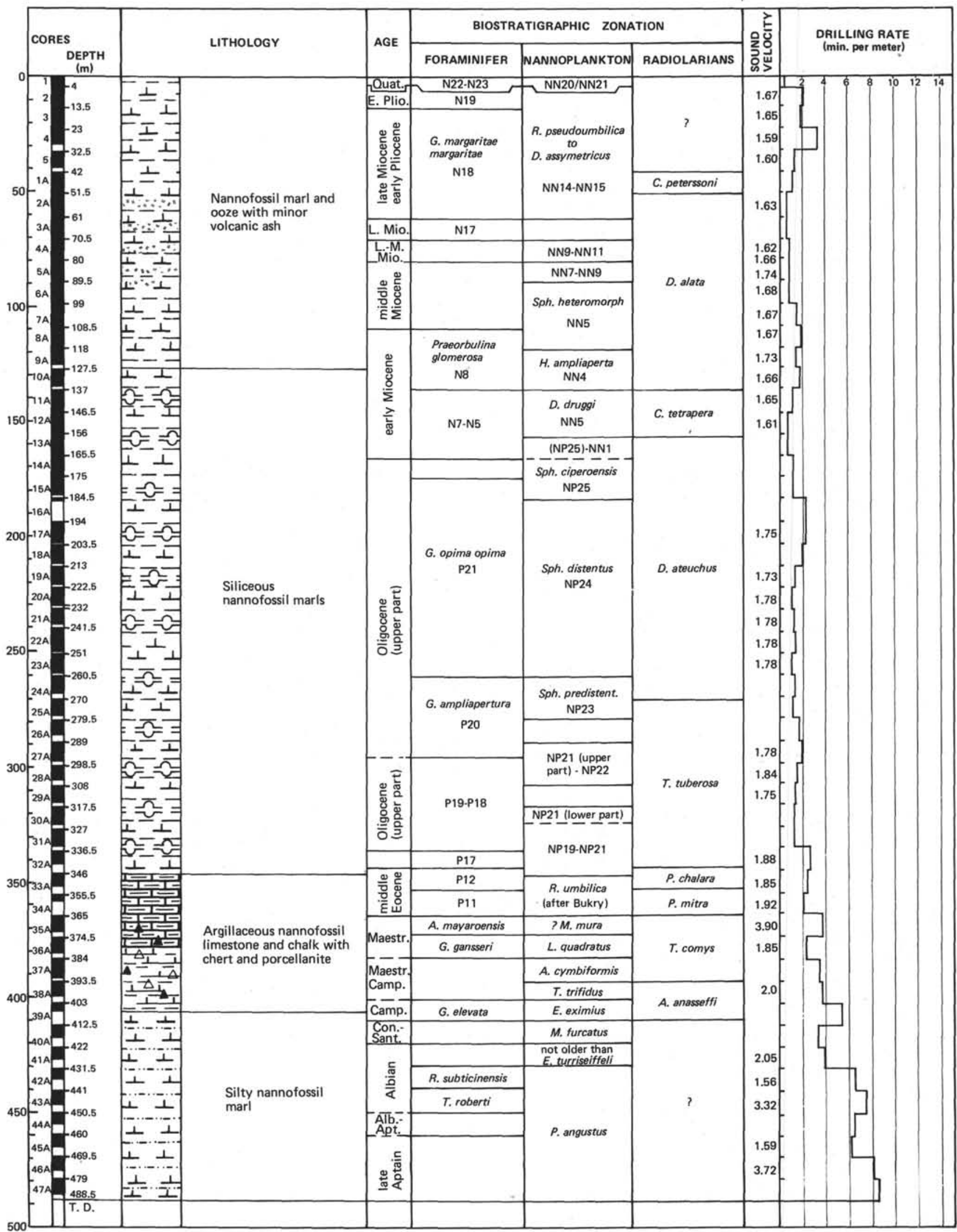

Figure 13. Graphic summary of lithology, age, biostratigraphy, sonic velocity, and drilling rate for Site 369. 
altogether they represent a gap of about 43 m.y. missing from a total record of about 105 m.y. An interesting correlation between physical properties data and the late Pliocene hiatus is found. The shear strength values from sediments just below the hiatus indicate possible removal of about 40 meters of overburden. The hiatuses might be partly due to slumping although these features appeared to be only intraformational and are neither very abundant nor very thick. Only four separate relatively massive slumps, with thicknesses of about $5.70 \mathrm{~m}, 4.80 \mathrm{~m}, 3.70 \mathrm{~m}$, and $7.00 \mathrm{~m}$, respectively, are present and none produced significant disturbances in the stratigraphy. Slumping might have been triggered by tectonic activity related to the Oligocene orogenic phase observed in the Atlas. They might also be related to increase in the angle of the slope following subsidence or to instability of the upper slope sediments during regression phases (Eocene-Oligocene?) or simply to critical values of sediment cohesion and overload. The hiatuses might also result from erosion and/or nondeposition by current circulation, e.g., in closely spaced canyons and their tributaries, although no direct indications have been observed in the sediments that would support such an origin.

\section{Diagenesis}

The sediments are generally poorly to moderately lithified as is commonly observed under the overburden conditions encountered at that site. The presence of well-crystallized argillaceous limestone (often dolomitic), however, is surprising. It is particularly intriguing to find well-crystallized limestone overlying chalk whereas the overall composition in both lithologies appears almost identical (in smear slides). The cementation of the limestone results from precipitation of crystals of microsparite rarely observed in deep-sea carbonate sediments that have not been covered by at least about 800 to 900 meters of overburden. The fact that microfossils remain abundant in these limestones suggests a foreign origin for the calcite cement. This particular lithification might have the same origin as other diagenetic products found in lower layers. Barite rosettes and needle-shaped crystals often replaced by calcite are found in the dark shaly and silty marl of early Cretaceous age. Their origin is not clearly established but an increase in the salinity of the interstitial waters toward the base of the hole suggests that they may have resulted from migration of solutions enriched in dissolved sulfates after leaching evaporite beds underlying the area. Such a migration might have occurred vertically or along the bedding planes of the slope anticline. Evaporites of Jurassic age are reported in Spanish Sahara and presence of evaporites beneath the continental shelf would not be surprising. Because of the sediment thicknesses of the pre-Aptian sediments as seen on the seismic profiles, however, such migration must have taken place over great distances before reaching the host sediments sampled at Site 369 . The origin of the calcite cementing the limestone and of the dolomite also present in the same beds might be the same as the origin of the calcite replacing the barite.

\section{Paleoenvironment}

The microfossils recovered from Site 369 are in general characteristic of slightly higher latitudes (still subtropical) than at the previous sites. Furthermore, they show (particularly the radiolarians) some affinities with the Mediterranean microfauna.

The overall productivity seems normal at this site. Some variations, however, are suggested by the variable amounts of radiolarians and diatoms. Because the site is located on the continental slope, the variations of productivity might be related to variations in upwelling conditions: Highest productivity seems to have occurred during the middle Miocene-Oligocene and Pleistocene times. The relative rarity of chert is quite surprising, especially since radiolarians are common in the middle Eocene sediments. These problems will require more detailed investigations.

\section{Significance of the Reflectors and Evolution of the Slope}

The correlations between lithology and seismic reflectors (Figure 12) are not very easy because these reflectors are not sharpiy defined. However, the acoustic velocities measured on core samples seem in good agreement with the inferred interval sound velocities and provide a relatively good basis for correlations. These measured velocities show a regular, almost linear, increase related to the depth of burial in the sediments and average about 1.65 to $1.8 \mathrm{~km} / \mathrm{sec}$.

Reflector $D_{1}$ corresponds probably with the very abrupt lithological change from silty nannofossil marl to underlying hard argillaceous nannofossil limestone. This lithological boundary separates middle Eocene from uppermost Eocene sediments with a possible hiatus present between the two sediment types. The Cretaceous-Tertiary boundary, marked by a hiatus where Paleocene and early Eocene sediments are missing, lies only about 26 meters below the abrupt lithological change and could also eventually be in part associated with the reflector although the hiatus itself is not apparent in the lithology. This reflector is younger than the age predicted by Seibold and Hinz (1974) who tentatively correlated it with a Cenomanian unconformity observed in Spanish Sahara drill holes. However, the sediments below the reflector might have different ages because, along the seismic profile, it appears to correspond with an angular discordance (see Figure 2).

Reflector $\mathrm{D}_{2}$ corresponds to the change, during the early Miocene, from siliceous nannofossil marls to overlying nannofossil marls. The boundary between the two lithologies is marked by an abrupt increase in siliceous microfossil content, a correlative drop in the carbonate values also accompanied by noticeable increases in the dissolution of the nannofossils and a change in porosities. The early Miocene age for this reflector is in good agreement with the prediction of Seibold and Hinz (1974). It is difficult to follow Reflector $\mathrm{D}_{2}$ along the slope of the seismic profile around Site 369 because the Meteor profile is discontinuous. More detailed analysis of the problem will be undertaken during Leg 47 .

\section{Continental Slope Sediments and the Evolution of the Continental Margin}

The data acquired at Site 369 allow only a very tentative interpretation of the evolution of the continental slope off Cape Bojador, in the context of a subsiding "rifted" continental margin. 

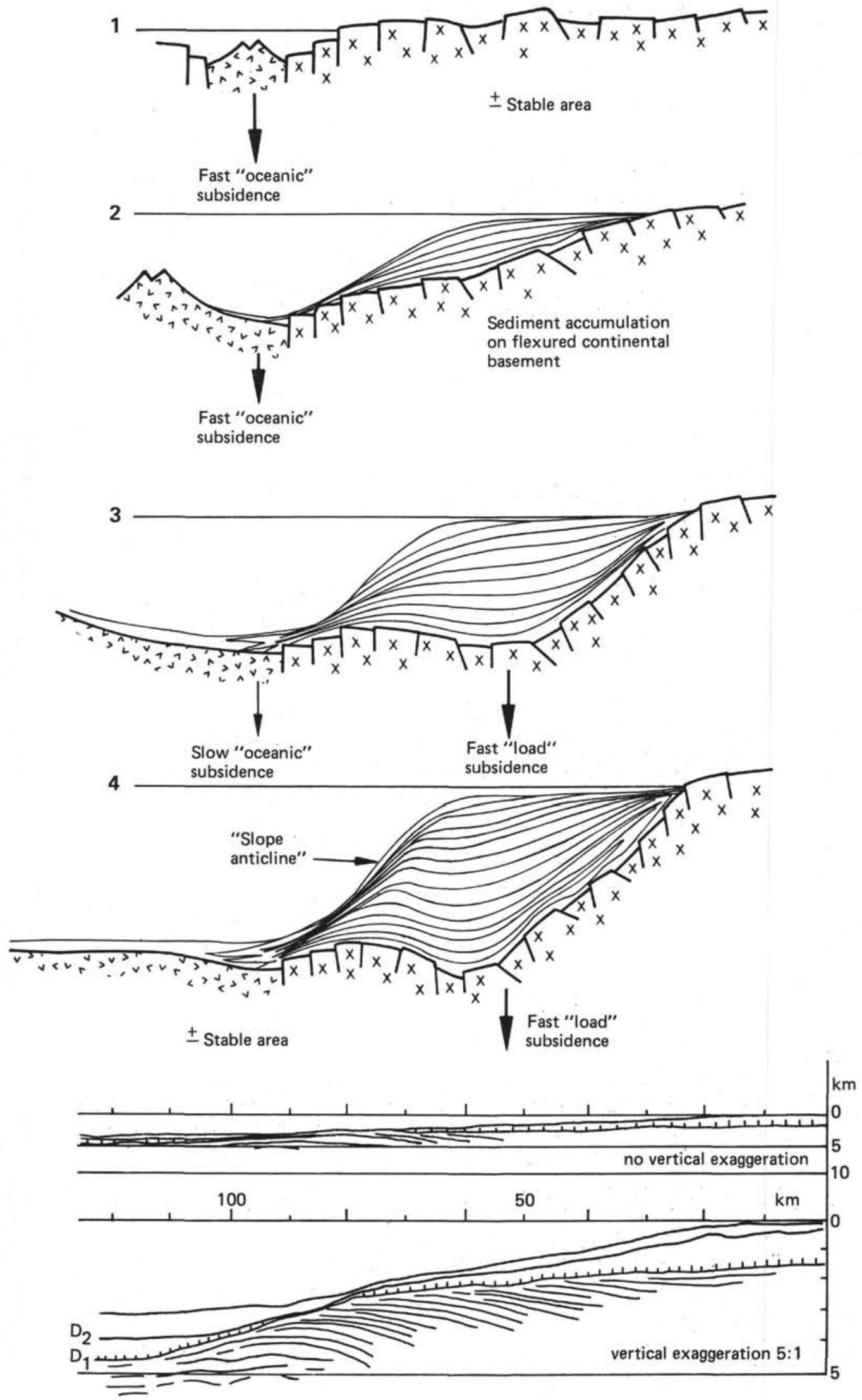

Figure 14. Four successive phases in the schematic evolution of the continental margin off Cape Bojador. Lower line drawings interpreted from actual seismic profiles. 
If we assume that the slope anticline results from a deep-seated feature such as a basement high of continental or intrusive origin, capped or not by a reef system or carbonate platform-and is not an "active" feature directly correlated with the nearby Atlas orogenic events or with salt tectonics-then we can imagine the following phases of evolution (Figure 14):

1) We assume that no thick sedimentary basin existed at the time of the breakup of the continental block. Block faulting of continental crust occurred and the first oceanic crust appeared between the two separated continental masses. Because the oceanic crust lies deeper than the continental crust (theoretically around $3000 \mathrm{~m}$ ), a graben developed at the edge of the continental masses.

2) Because subsidence of the oceanic crust proceeded rapidly, due to cooling of the lithosphere and increasing distance from the Mid-Atlantic Ridge, the edge of the continental block subsided at the same rate. Coarse terrigenous sediments accumulated on the inner part of the shelf which began to subside under that load. Pelagic sedimentation then predominated in the slope area.

3) The rate of subsidence of the oceanic crust slows down markedly after about 50-60 m.y. of spreading, when the Mid-Atlantic Ridge was farther from the margin. If the outer part of the continental basement was coupled with the oceanic crust, then the subsidence of that area also slowed down. Meanwhile, the subsidence beneath the inner shelf is still fast under increasing load of coarse terrigenous-and biogenous benthic-material. If the terrigenous input was relatively poor, then sedimentation on the slope would have been predominantly pelagic. Differential subsidence, very slow beneath the slope, but rapid beneath the shelf, could have caused regular landward downwarping of the pelagic layers deposited on the outer shelf and slope, creating the "slope anticline" structure.

4) Because the terrigenous input was relatively poor (due to lack of large regressions or to climatic conditions), no progradation occurred and the slope remained in a predominantly pelagic environment while the shelf edge retreated. Another consequence of the lack of massive terrigenous deposition in the slope area was that the "slope anticline" remained very close to the sea floor.
5) This may have been accentuated by permanent or periodical erosion or nondeposition along the slope, caused by bottom current and/or slumping as illustrated by the disconformities underneath the continental slope off Cape Bojador.

\section{REFERENCES}

Dillon, W. P. and Sougy, J. M. A., 1974. Geology of West Africa and Canary and Cape Verde Island. In Nairn, E. M. and Stehli, F. G. (Eds.), The Ocean Basins and Margins: New York (Plenium Press), p. 315-390.

Furon, R., 1963. Geology of Africa: New York (Hafner Publ. Co.), p. 337.

Grunau, J. R., Lehner, P., Cleintauar, M. R., Allenbach, P., and Bakker, G., 1975. New radiometric ages and seismic data from Fuerteventura (Canary Islands), Maio (Cape Verde Islands), and Sao Tome (Gulf of Guinea). In Progress in Geodynamics: Amsterdam (Royal Netherlands Academy of Arts and Science), p. 90-118.

Hinz, K., Seibold, E., and Wissmann, G., 1974. Continental slope anticline and unconformities off West Africa: Meteor Forschung Ergebn., v. C-1, no. 17, p. 67-73.

Hollister, C. D., Ewing, J. I., et al., 1972. Initial Reports of the Deep Sea Drilling Project, Volume 11: Washington (U.S. Government Printing Office).

Riedel, W. R. and Sanfilippo, A., 1974a. Radiolaria from the southern Indian Ocean, DSDP Leg 26. In Davies, T. A., Luyendyk, B., et al., Initial Reports of the Deep Sea Drilling Project, Volume 26: Washington (U.S. Government Printing Office), p. 771-814.

1974b. Stratigraphy and evolution of tropical Cenozoic radiolarians: Preprint, Third Plankt. Conf., Kiel.

Sanfilippo, A., Burckle, L. H., Martini, E., and Riedel, W. R., 1973. Radiolarians, diatoms, silicoflagellates, and calcareous nannofossils in the Mediterranean Neogene: Micropaleontology, v. 19, p. 209-234.

Seibold, E. and Hinz, K., 1974. Continental slope construction and destruction, West Africa. In Burk, C. A. and Drake, C. I. (Eds.): The geology of continental margins: New York (Springer-Verlag), p. 179-196.

Thierstein, H. R., 1971. Tentative Lower Cretaceous calcareous nannoplankton zonation: Eclog. Geol. Helv., v. 64, p. $459-488$.

1973. Lower Cretaceous calcareous nannoplankton biostratigraphy: Abh. Geol. B. A., v. 29, p. 52.

, 1976. Mesozoic calcareous nannoplankton biostratigraphy of marine sediments: Marine Micropal., v. I, p. $325-362$. 


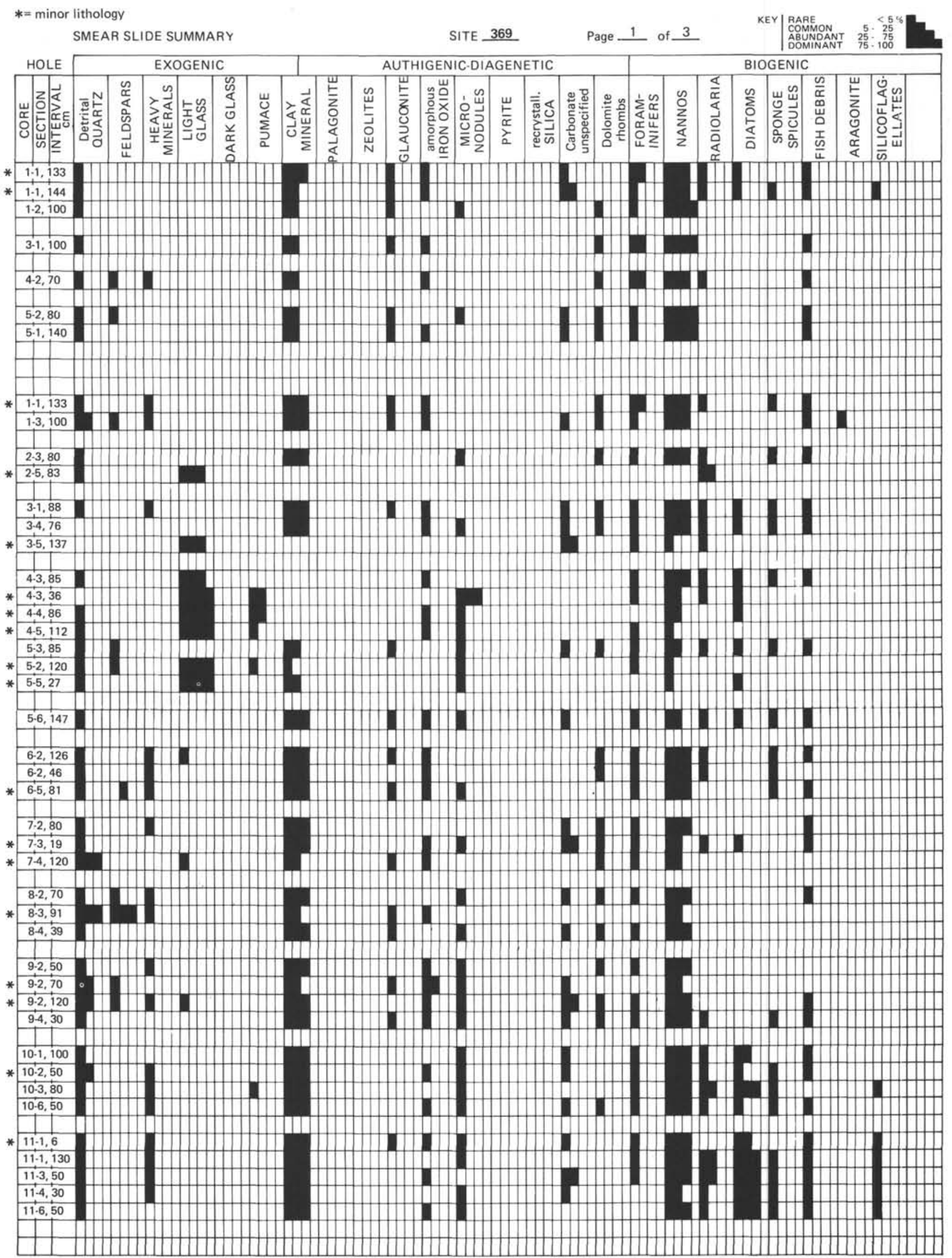




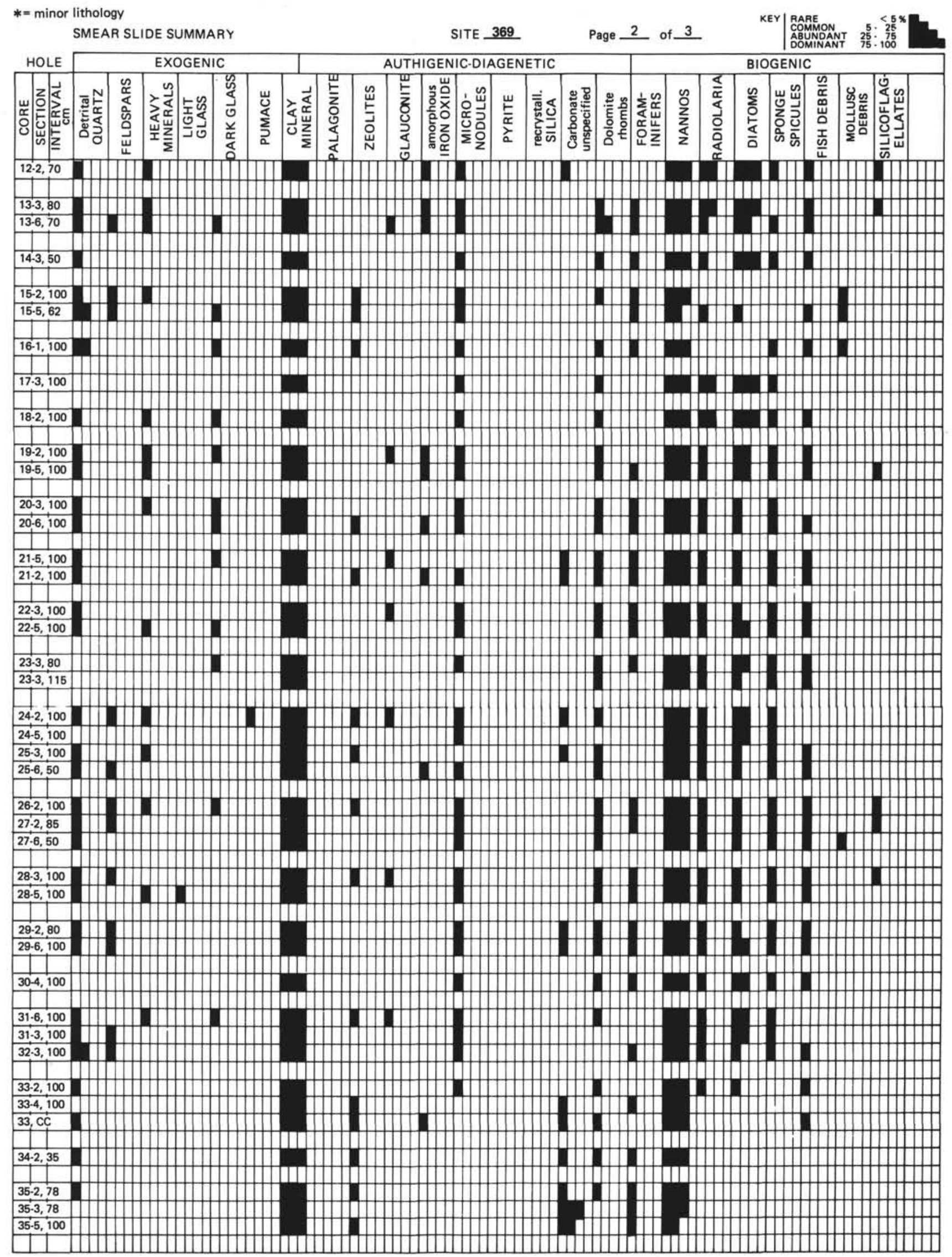




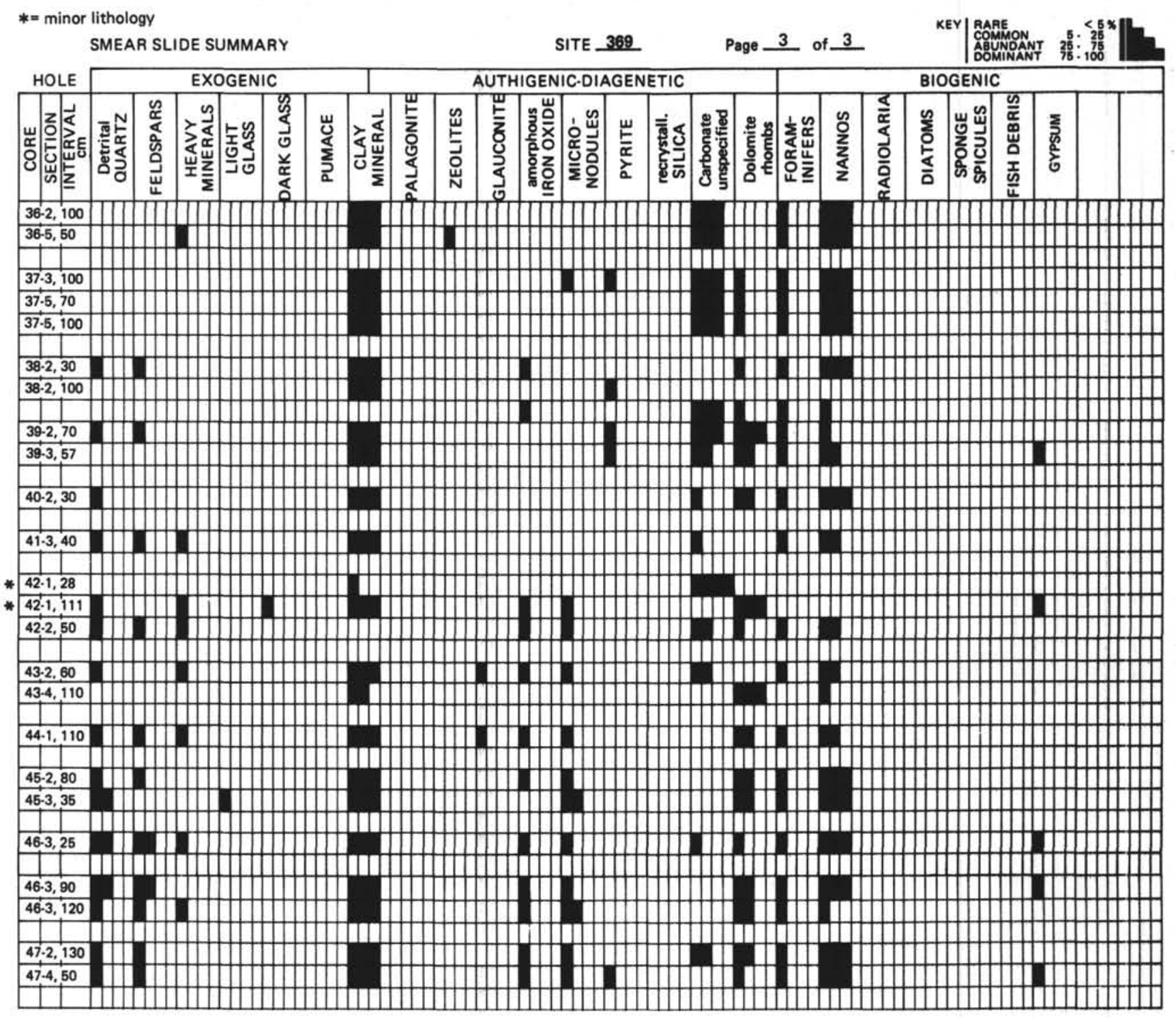




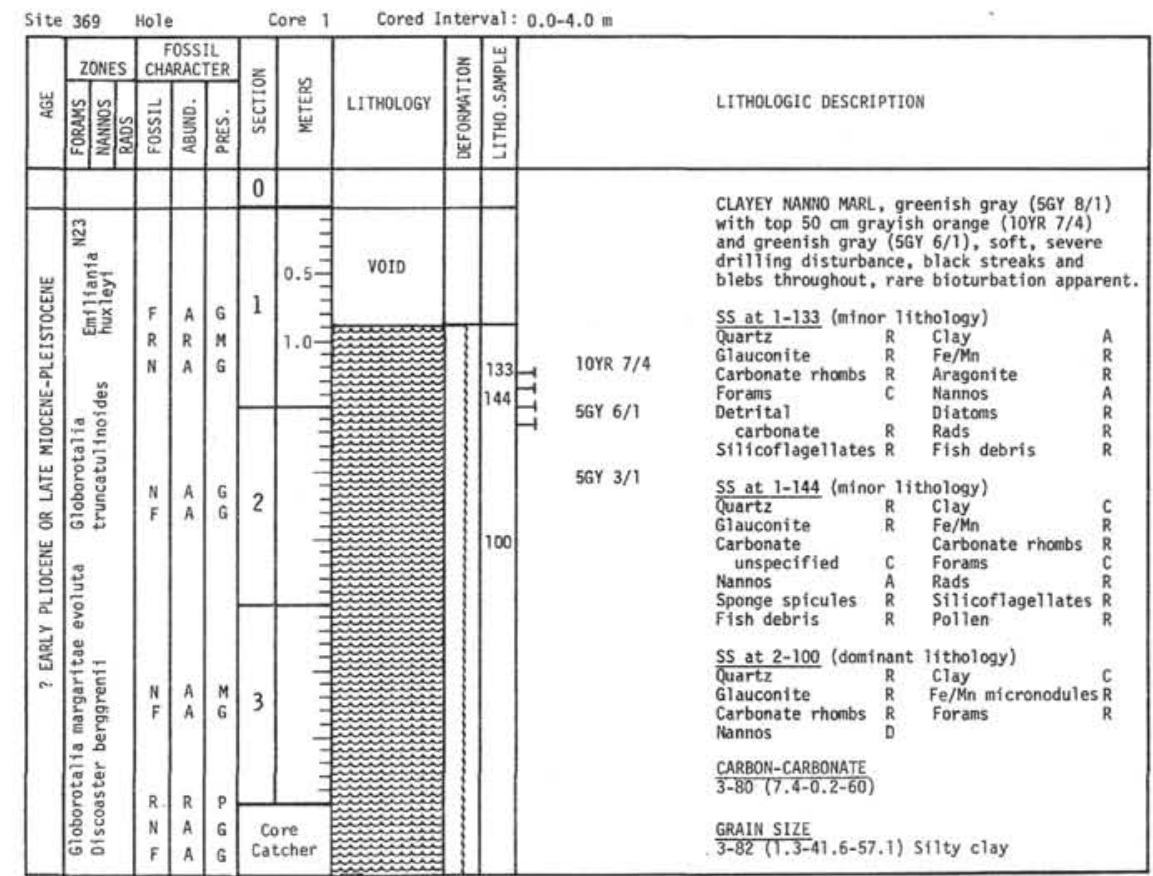

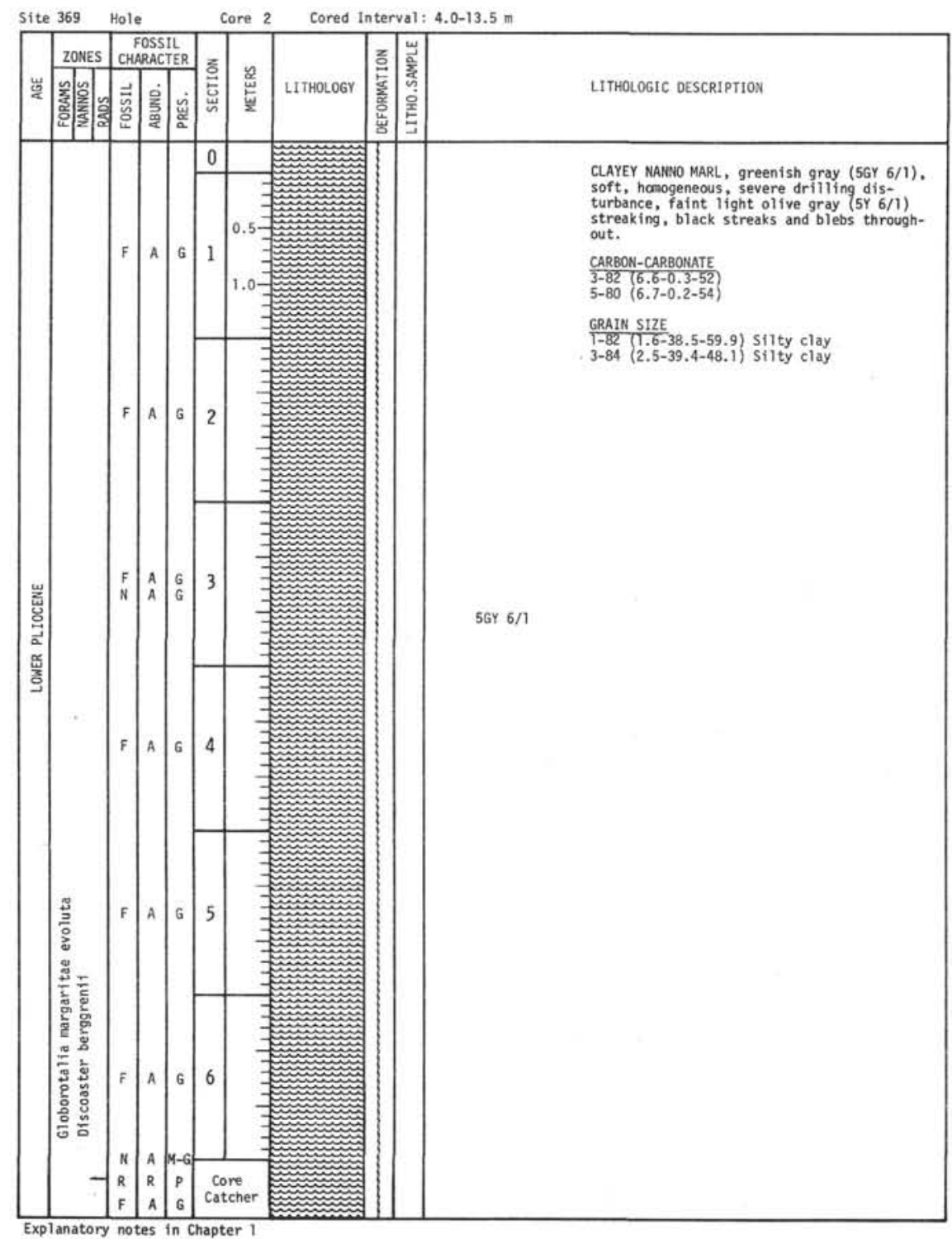



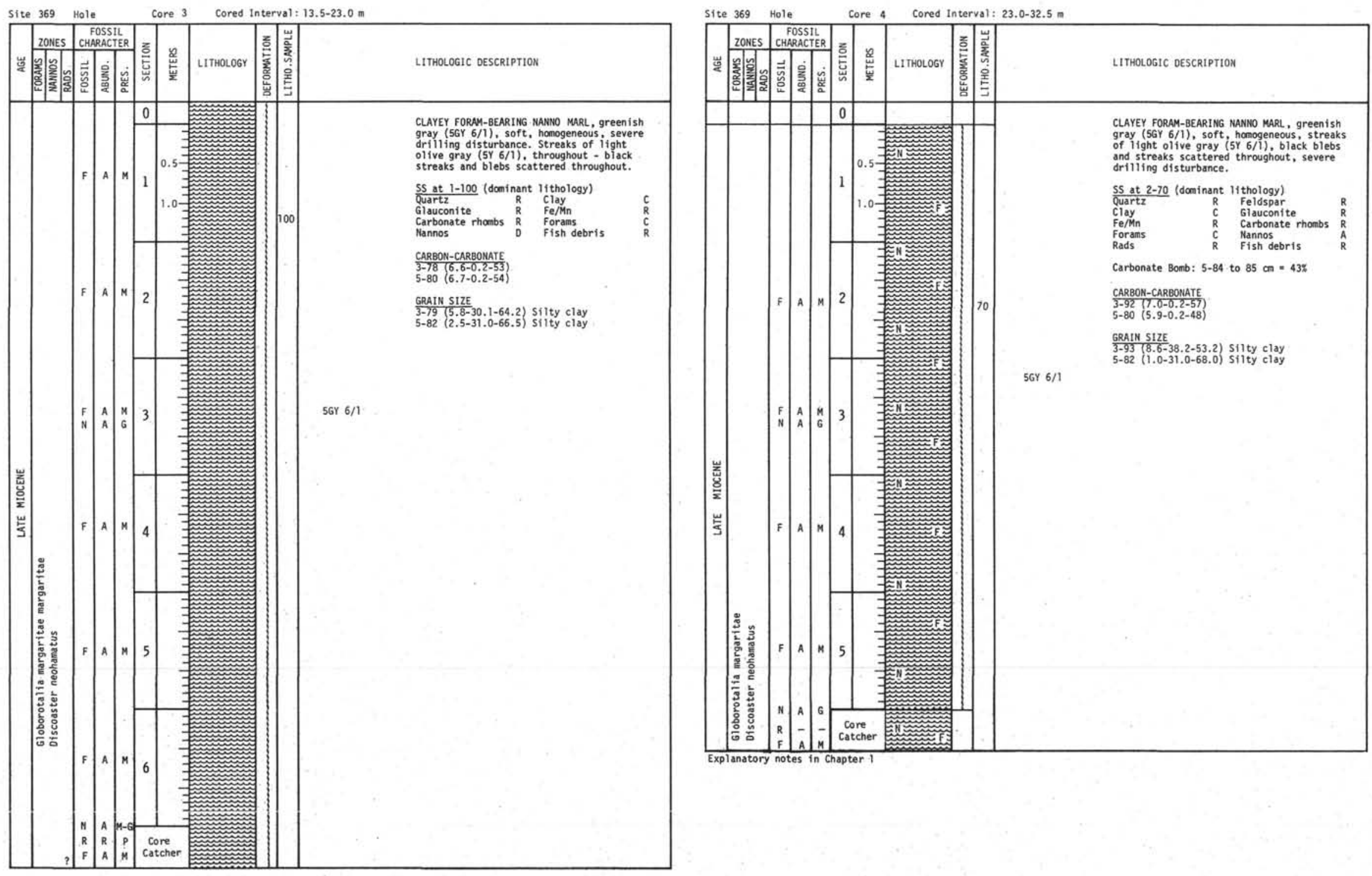


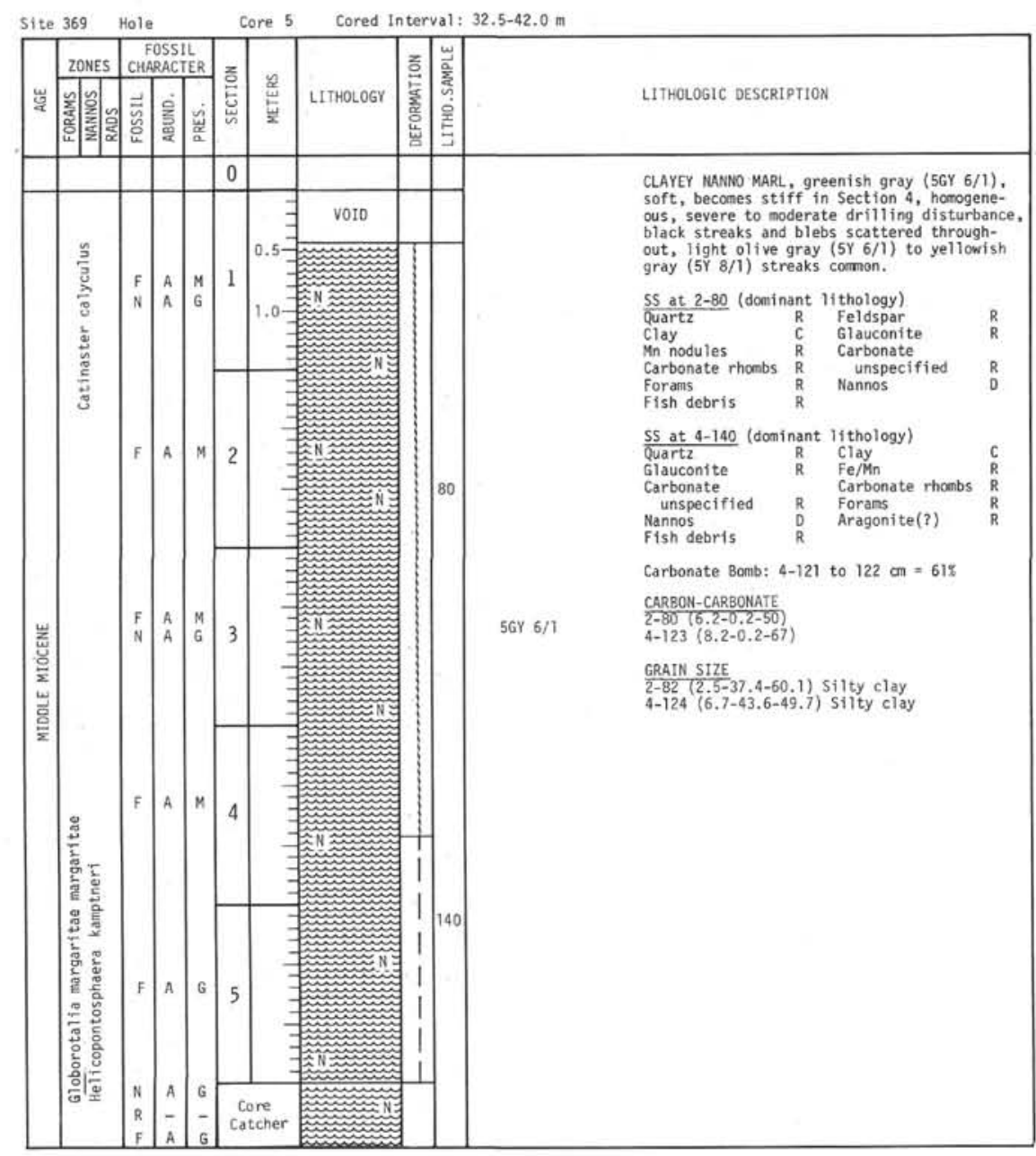

\begin{tabular}{|c|c|c|c|c|c|c|c|c|}
\hline t & 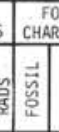 & 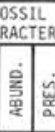 & & 竧 & LITHOLOGY & 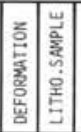 & & LITHOLLGIC DESCRIPTION \\
\hline 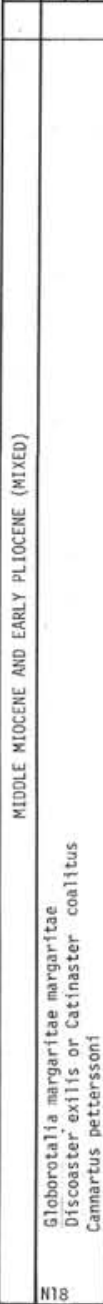 & $\begin{array}{l}\mathrm{R} \\
\mathrm{F}\end{array}$ & \begin{tabular}{l|l}
- & - \\
$M$
\end{tabular} & $\begin{array}{c}c_{0} \\
\text { Cat }\end{array}$ & $0.5 \frac{=}{=}$ & Lorn & 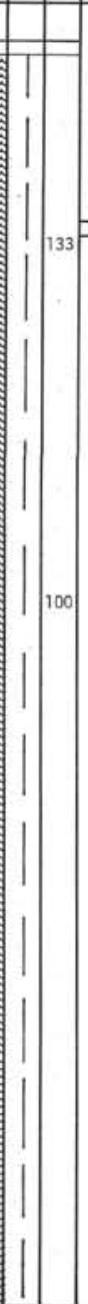 & $\begin{array}{l}\text { 56Y } 6 / 1 \\
\text { lorr } 6 / 6\end{array}$ & 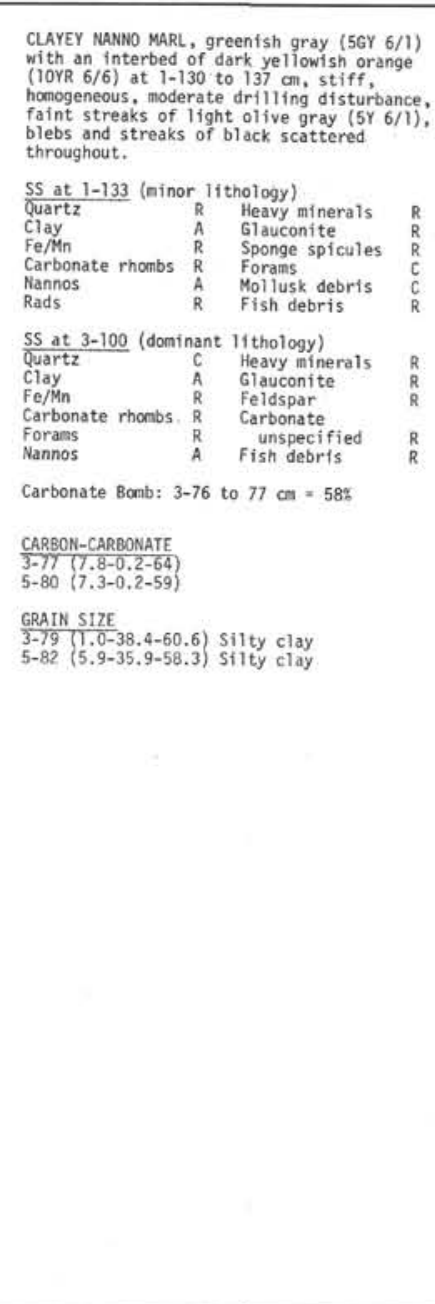 \\
\hline
\end{tabular}



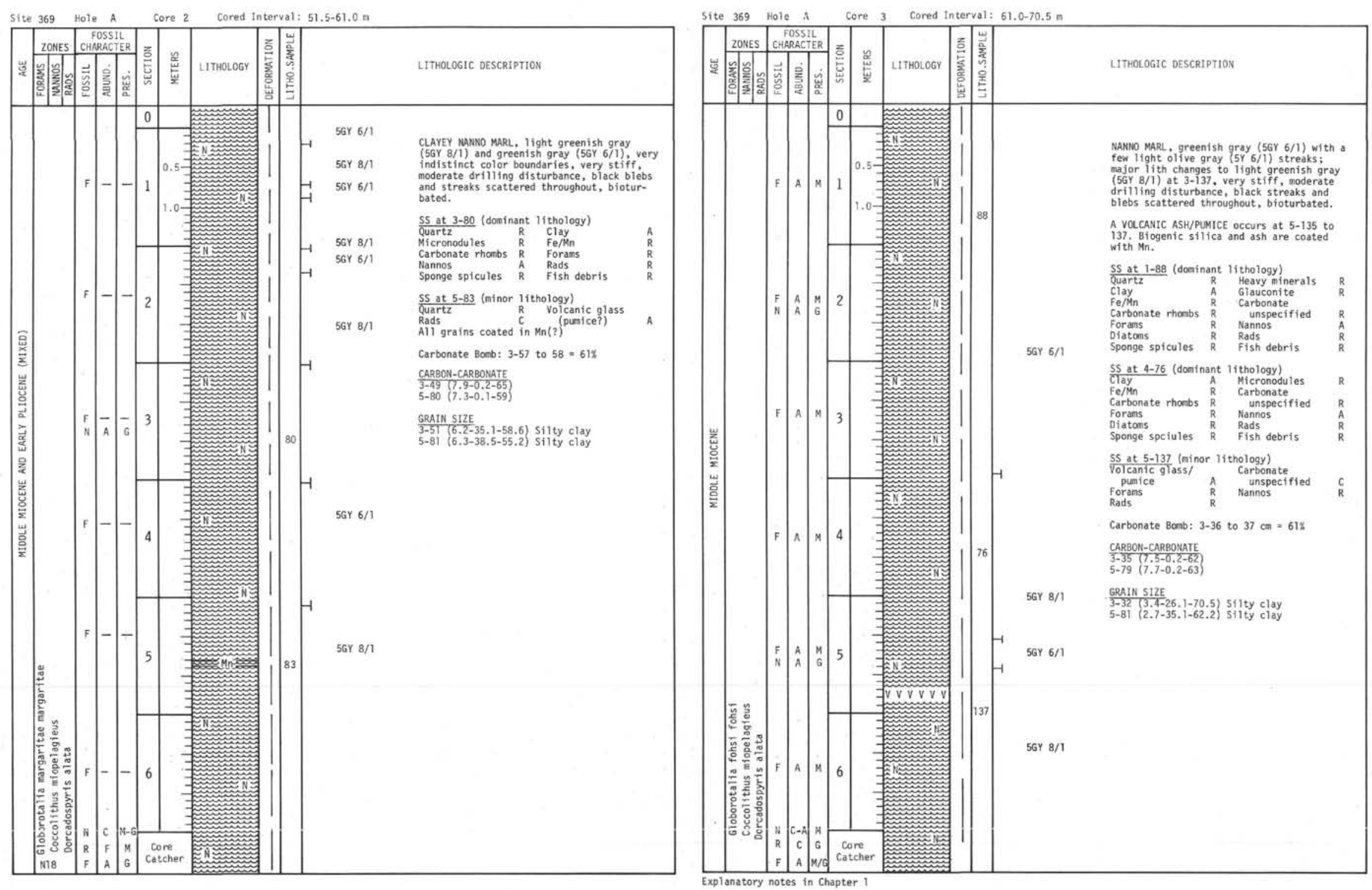

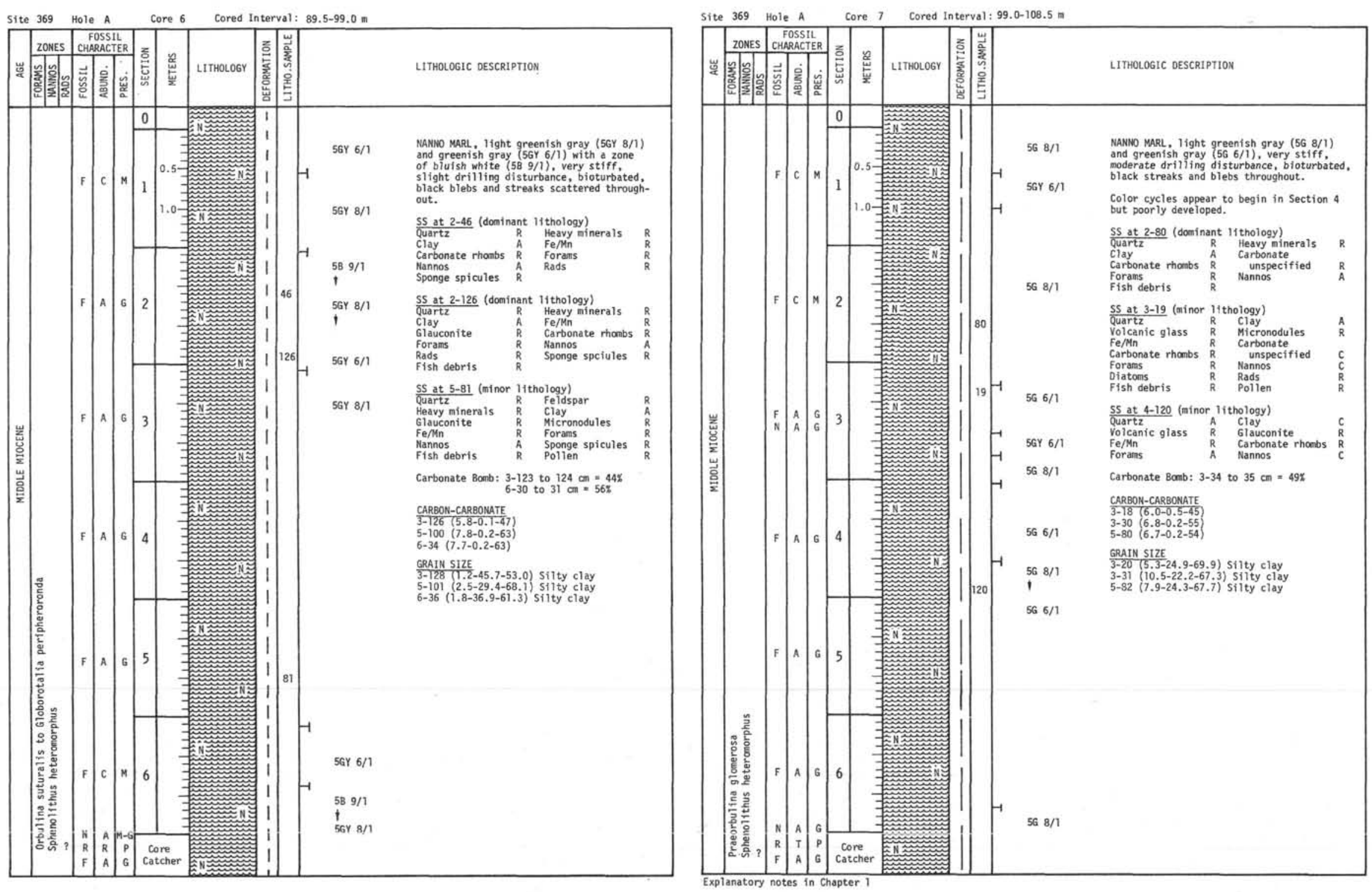

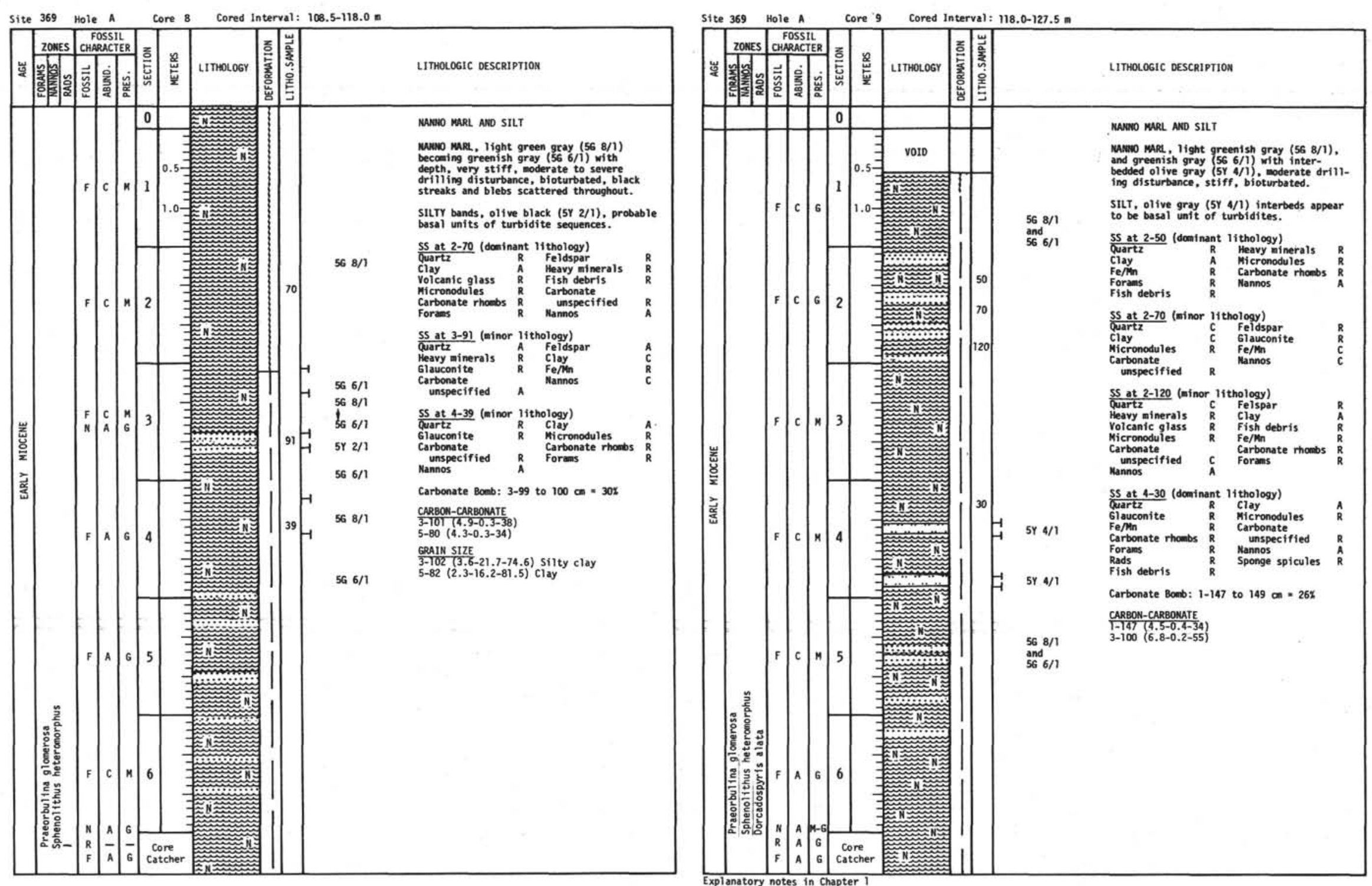

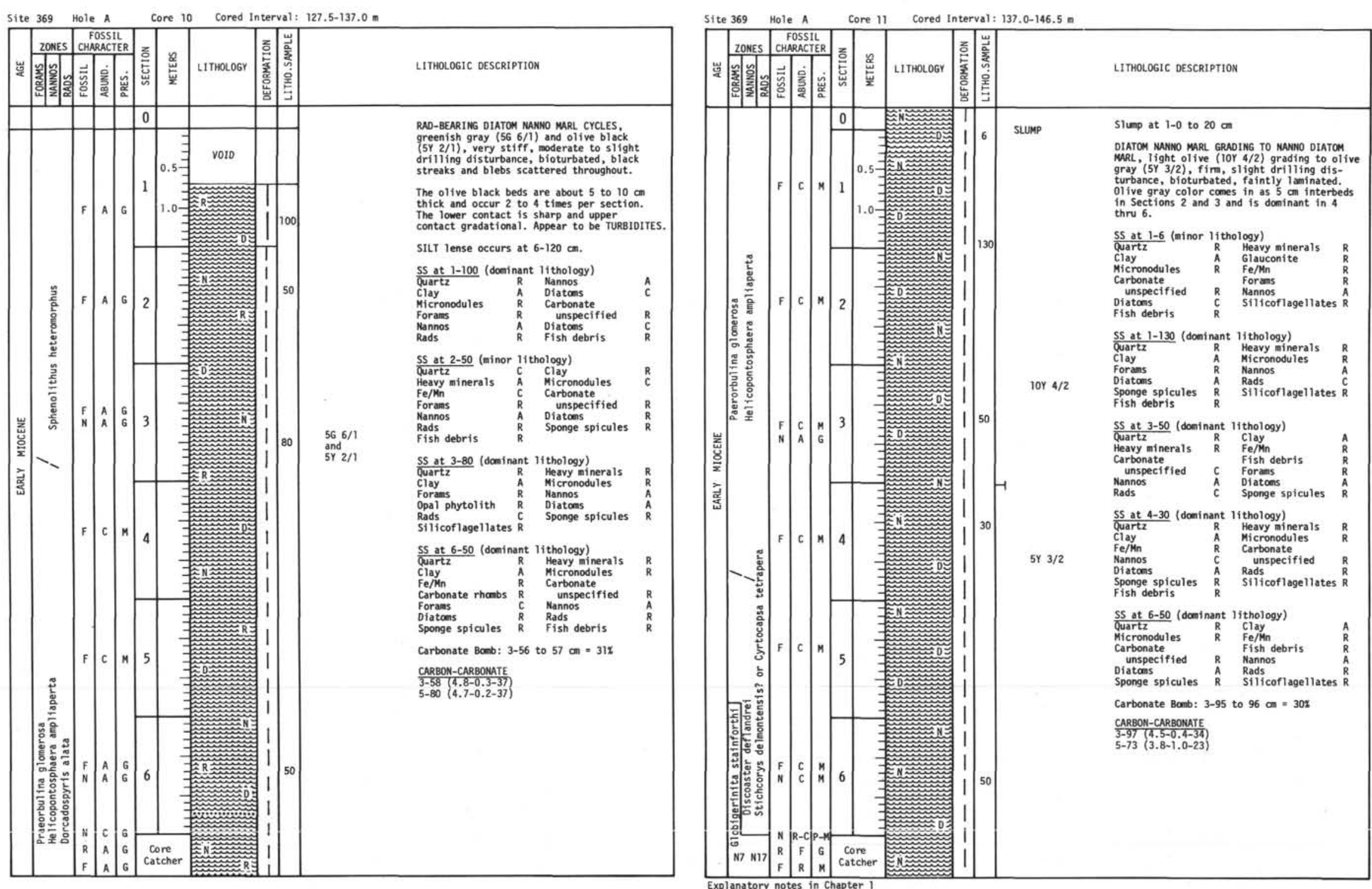

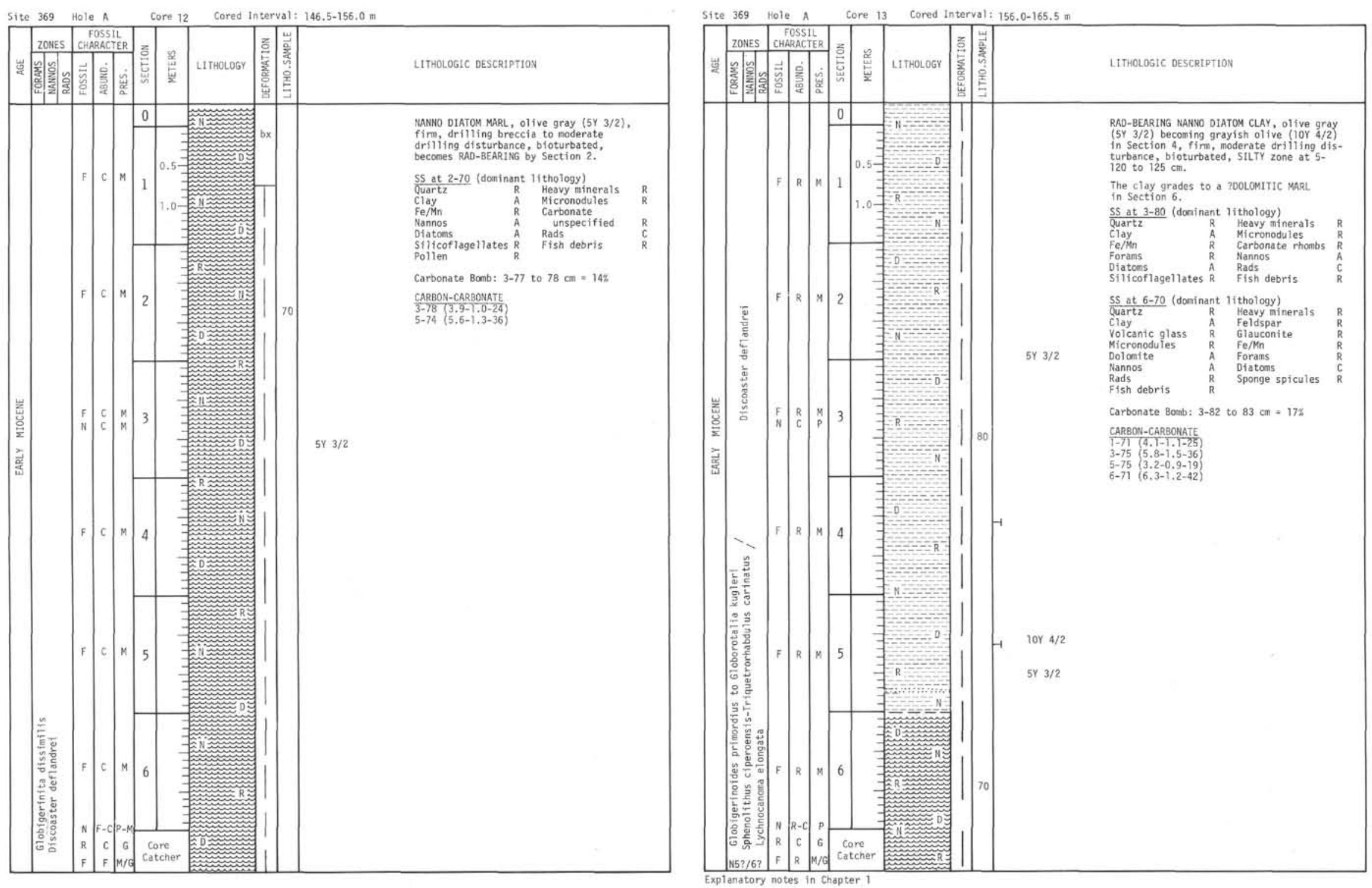

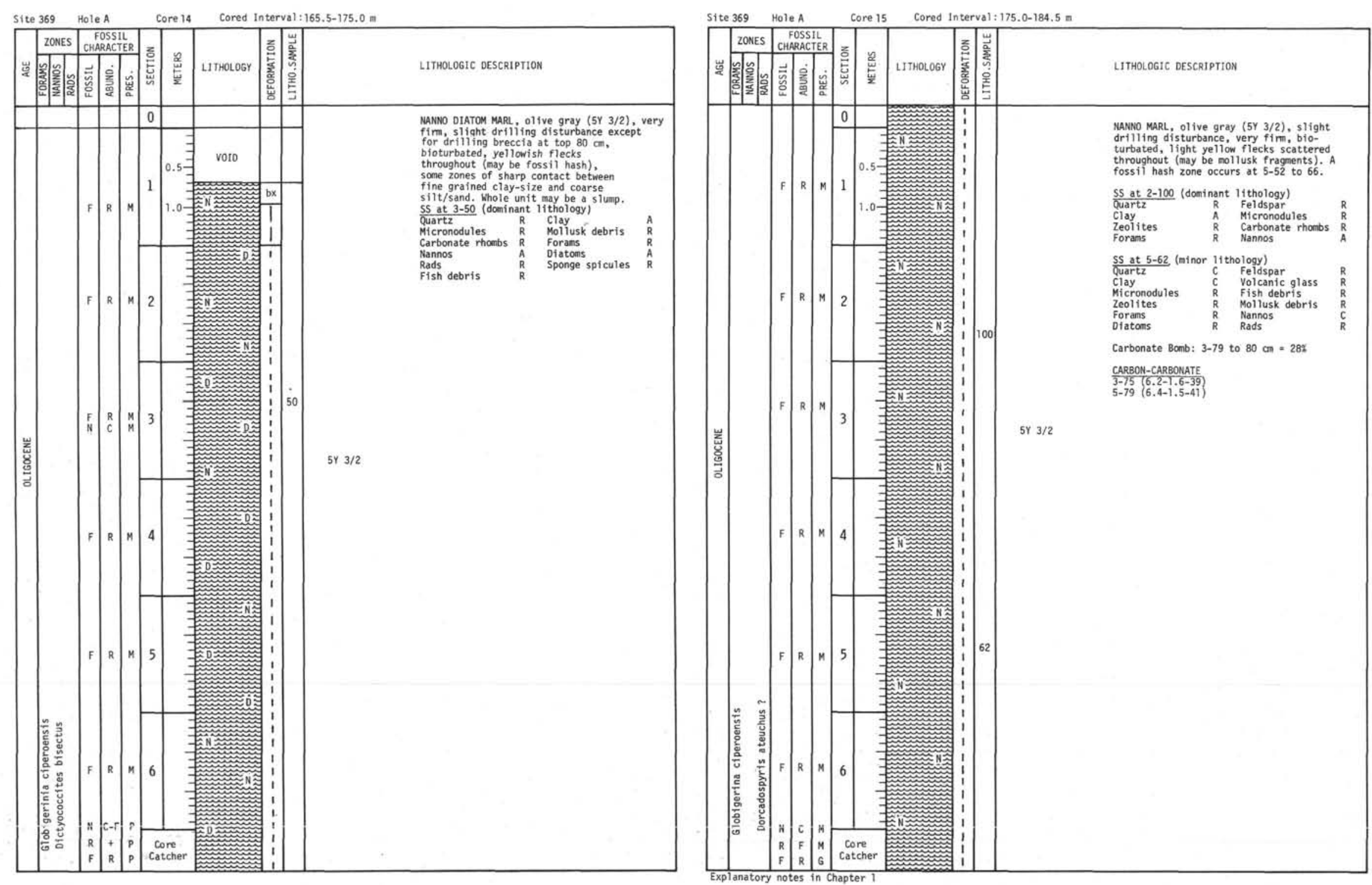


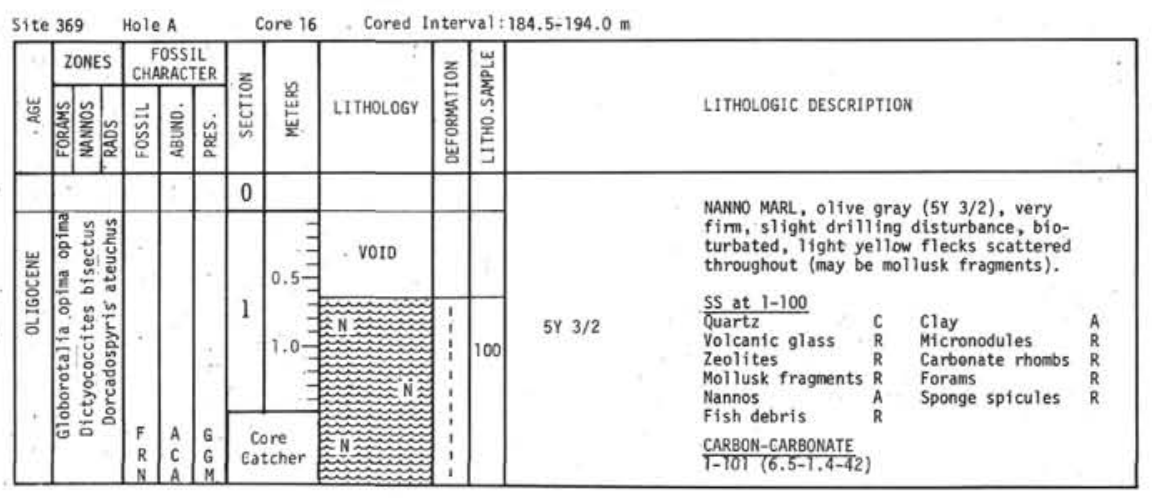

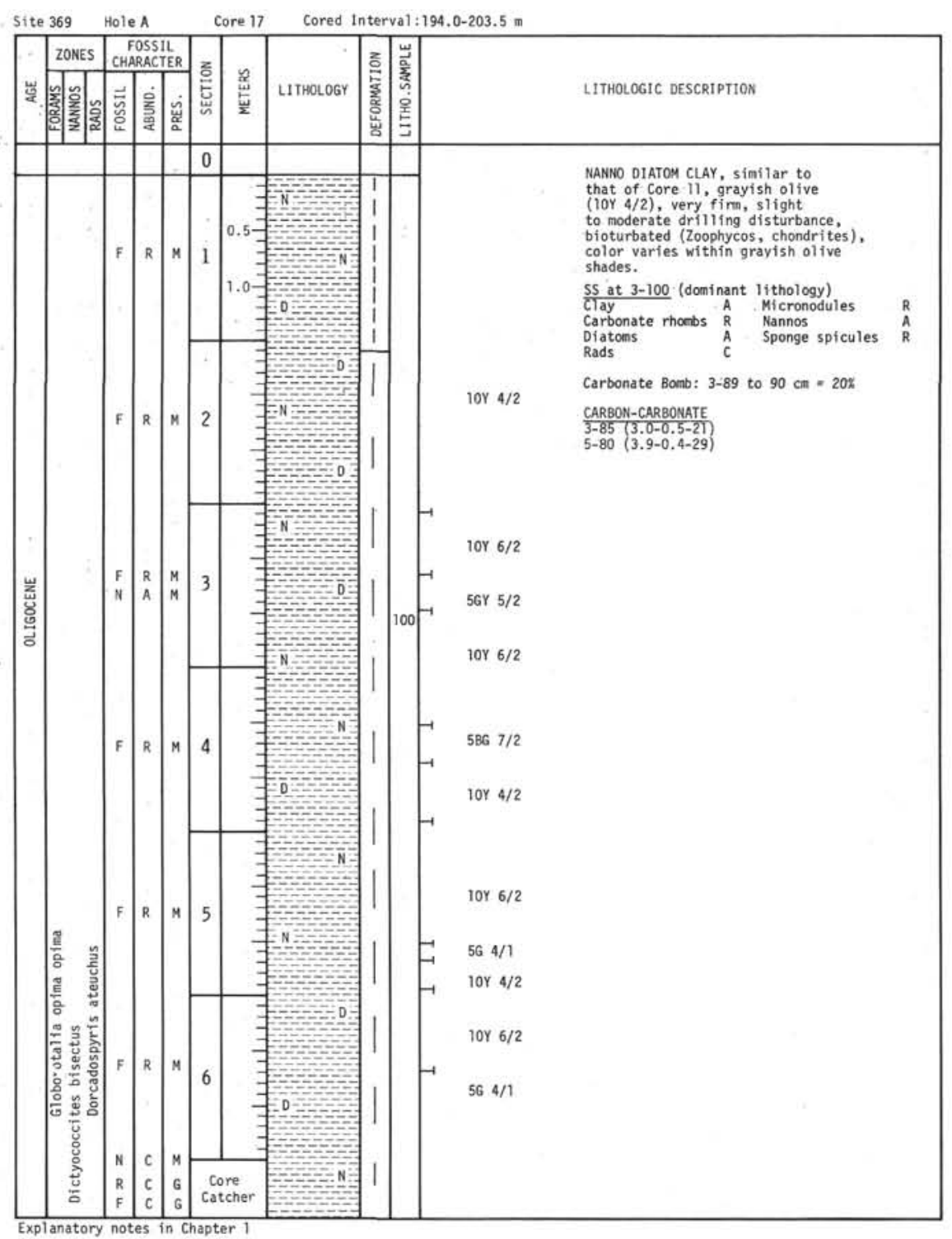




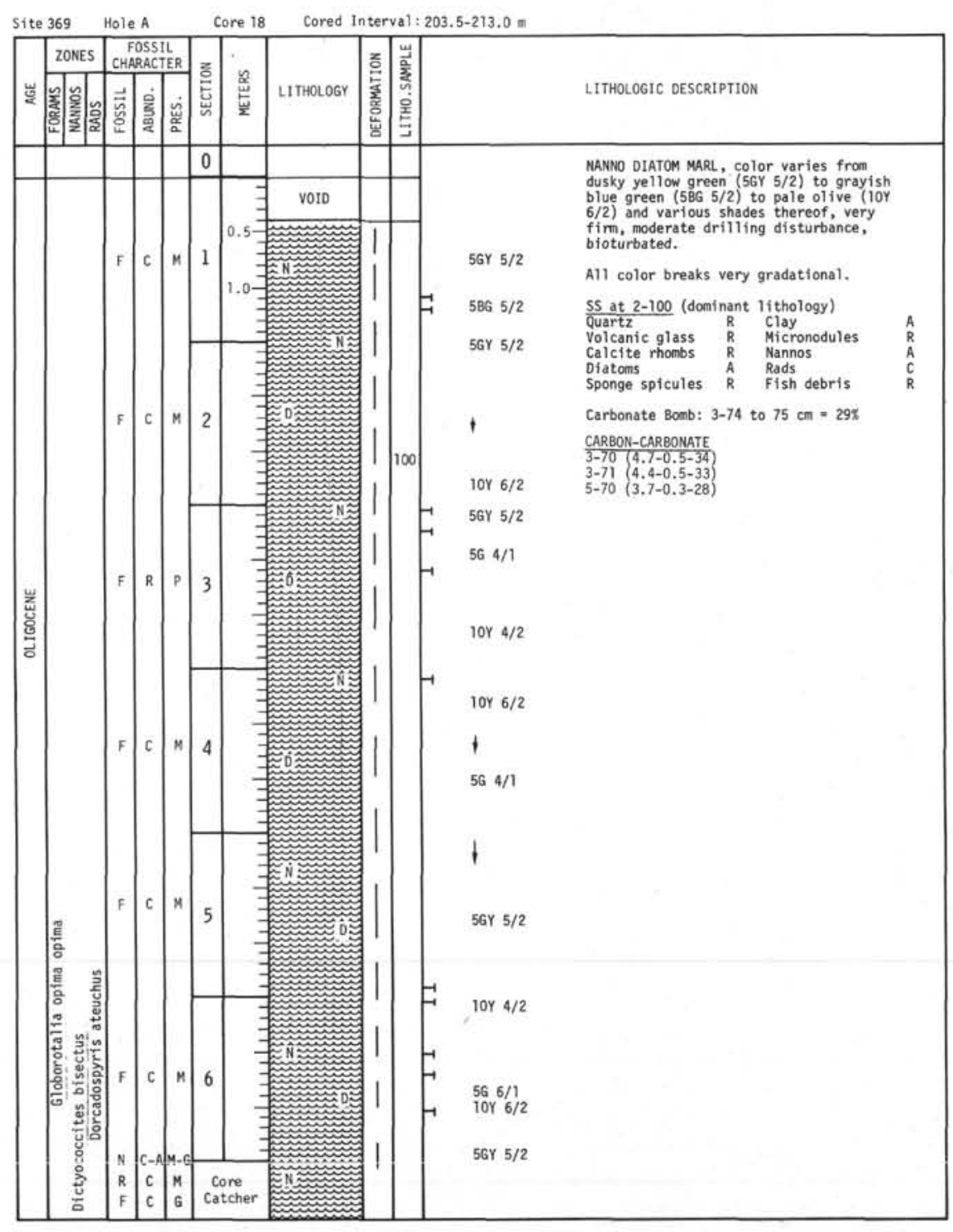

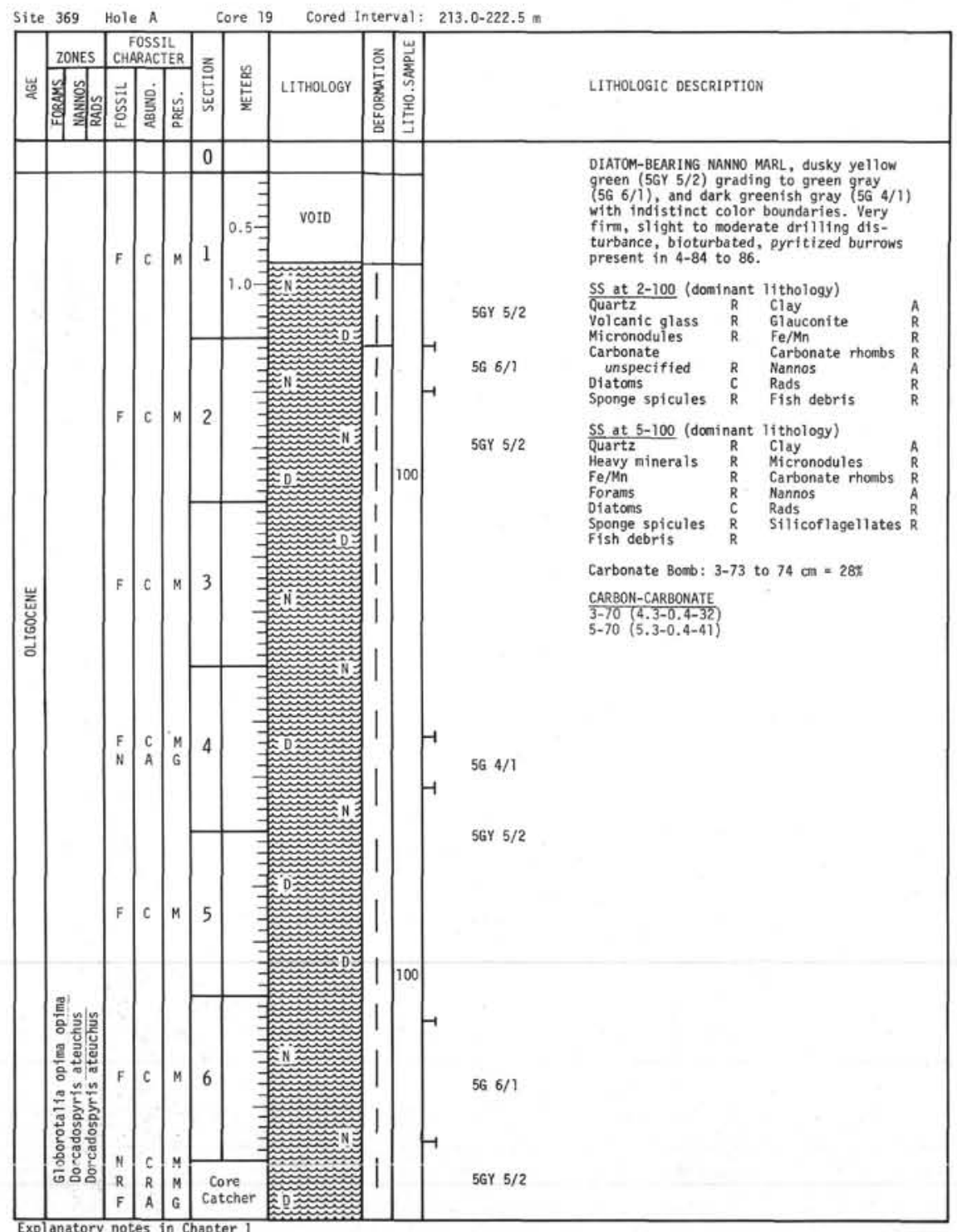




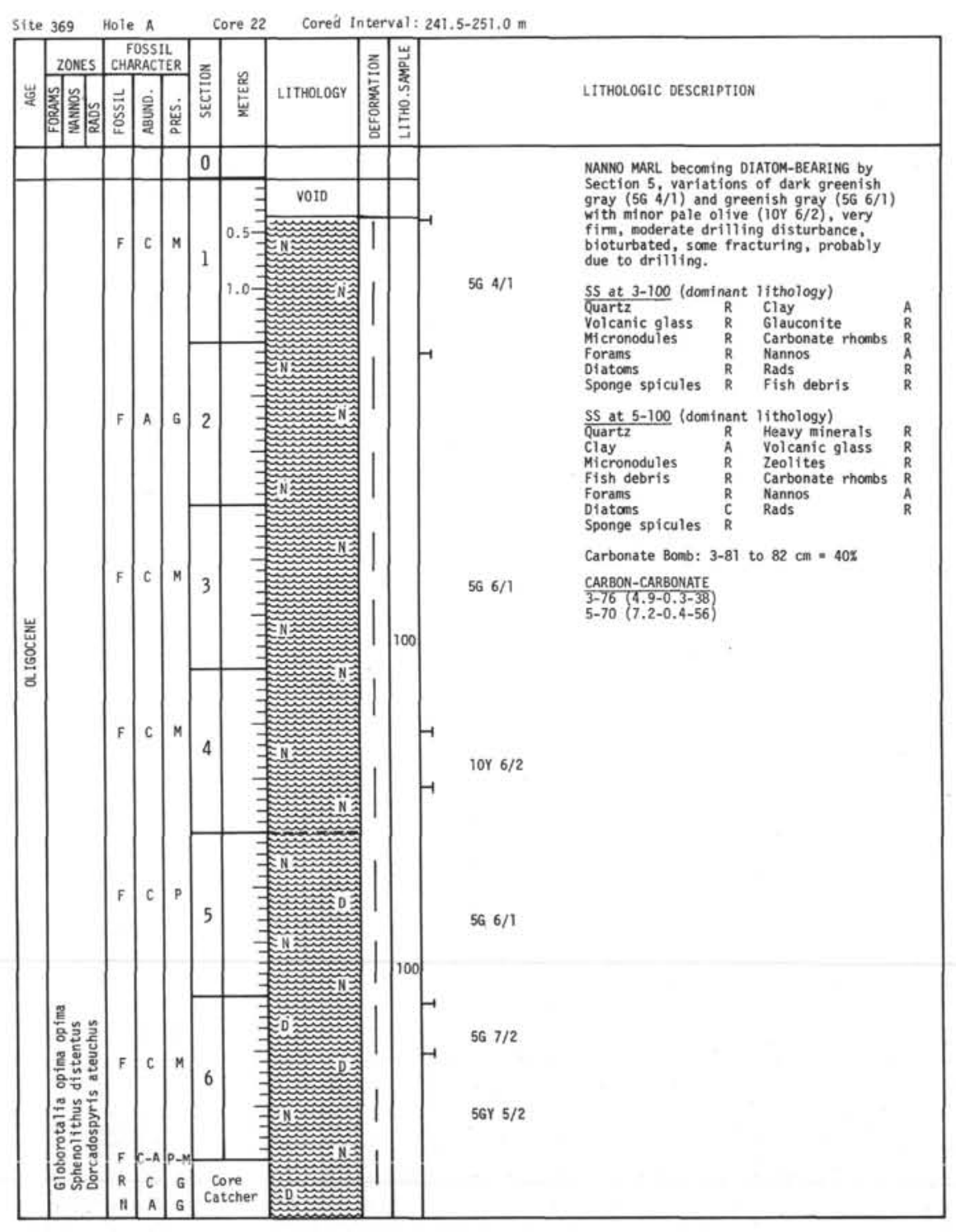

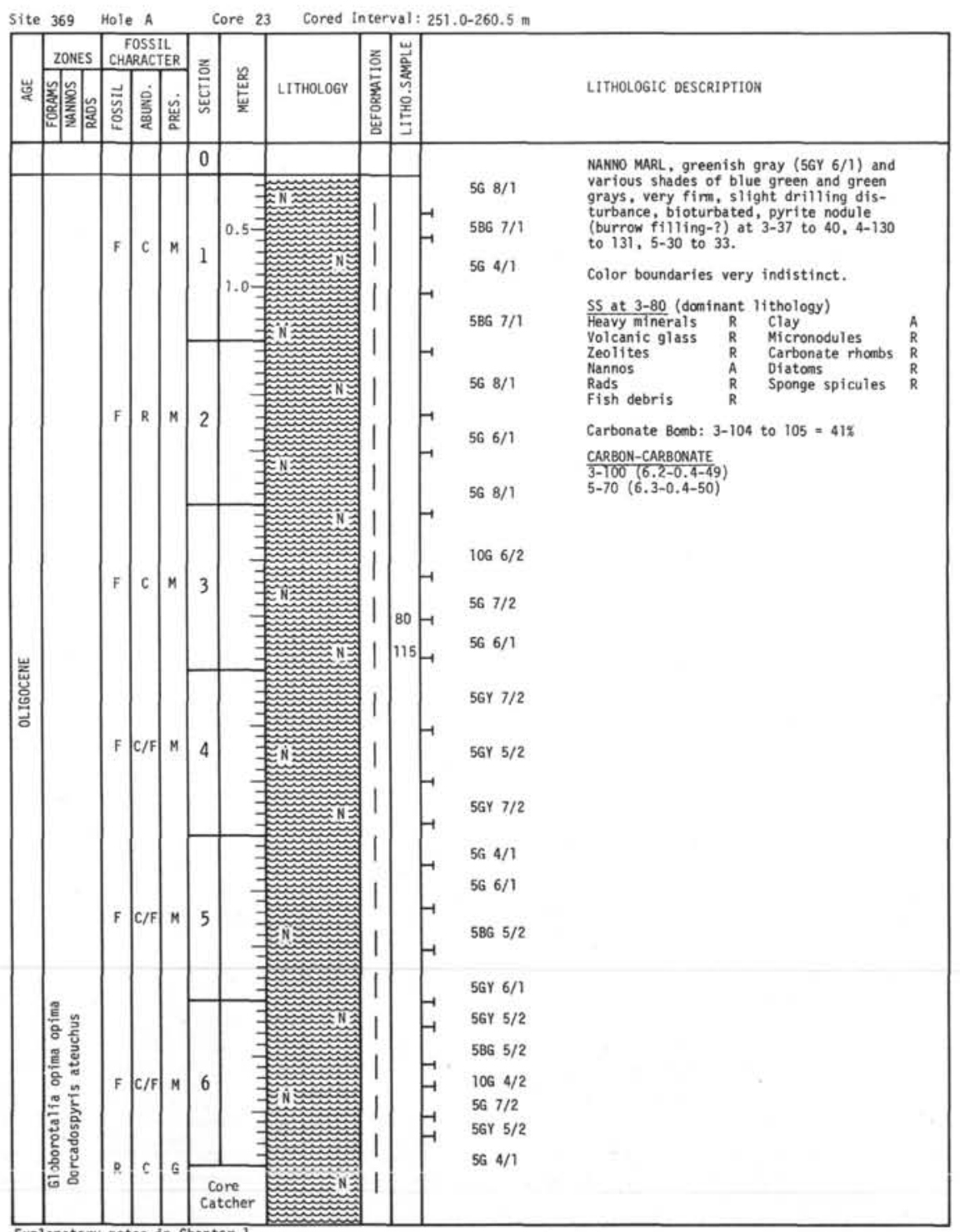




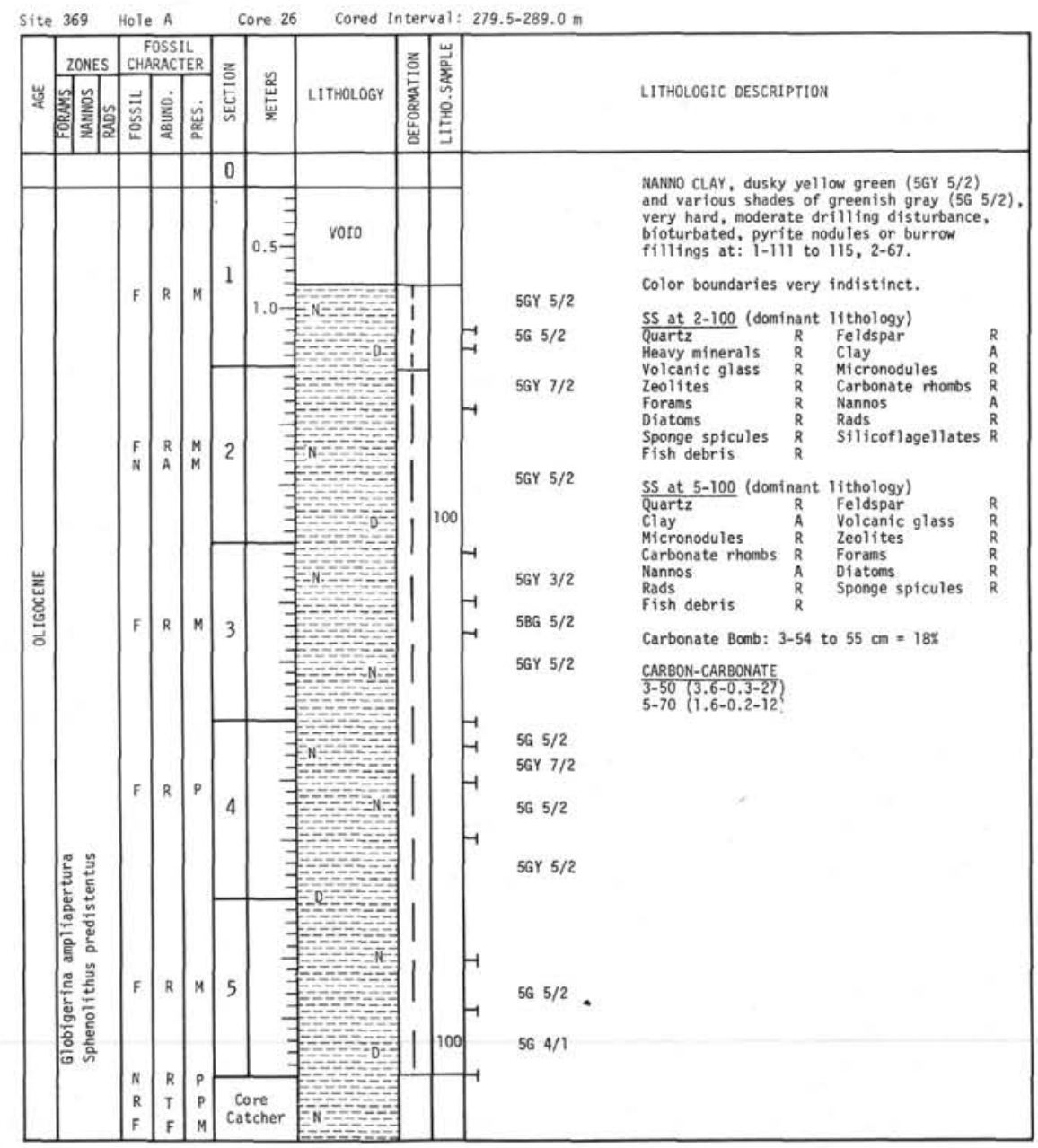

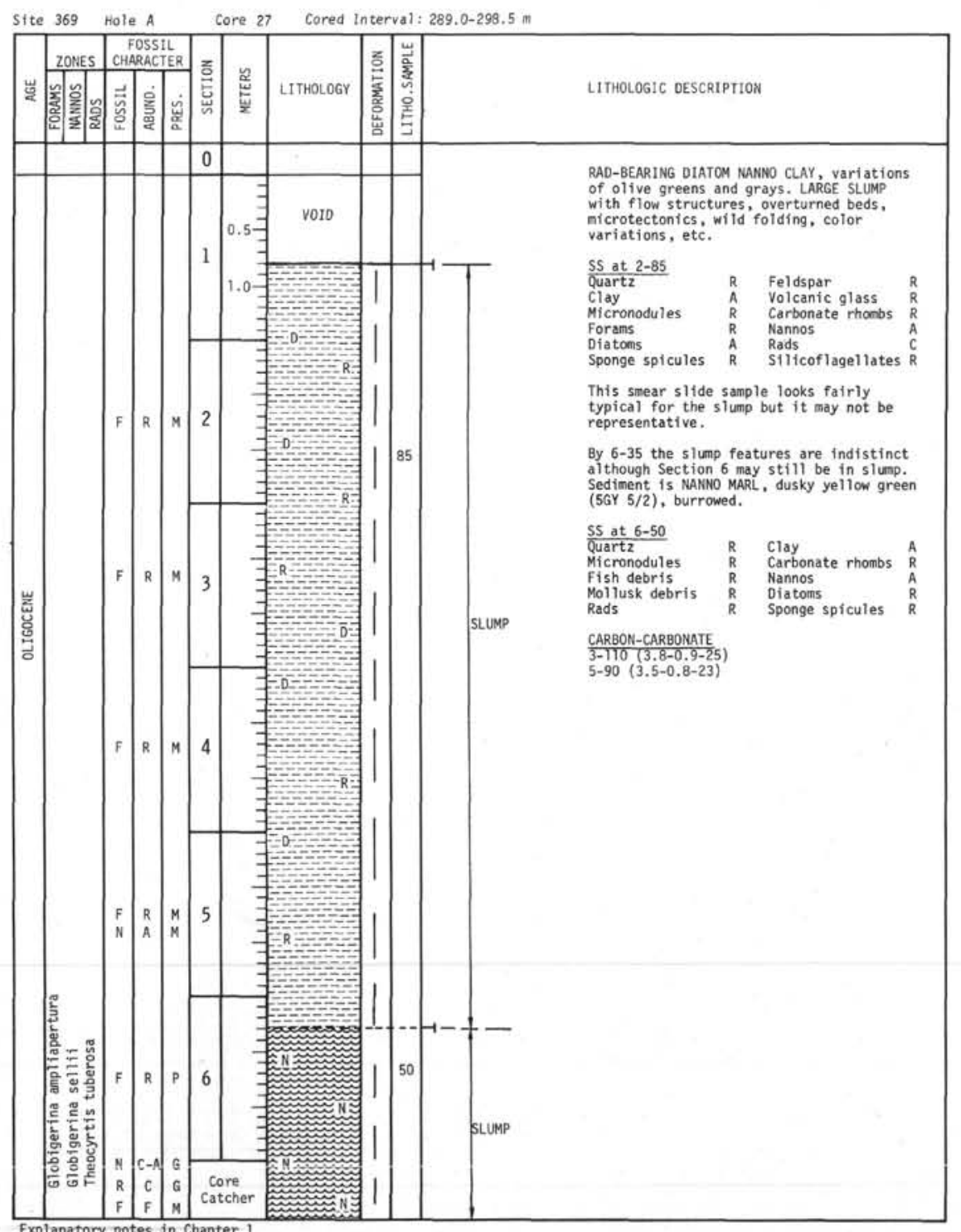



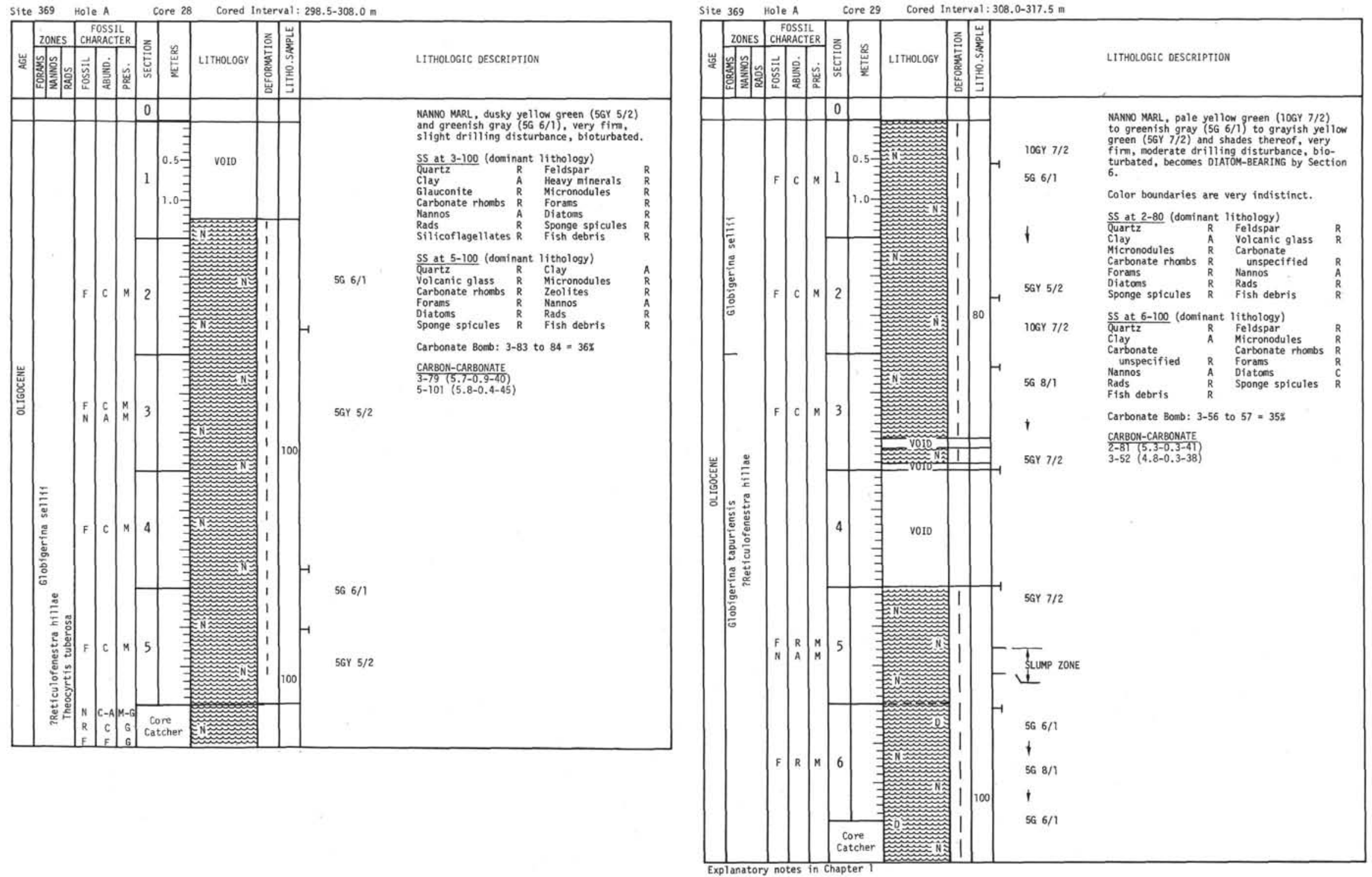


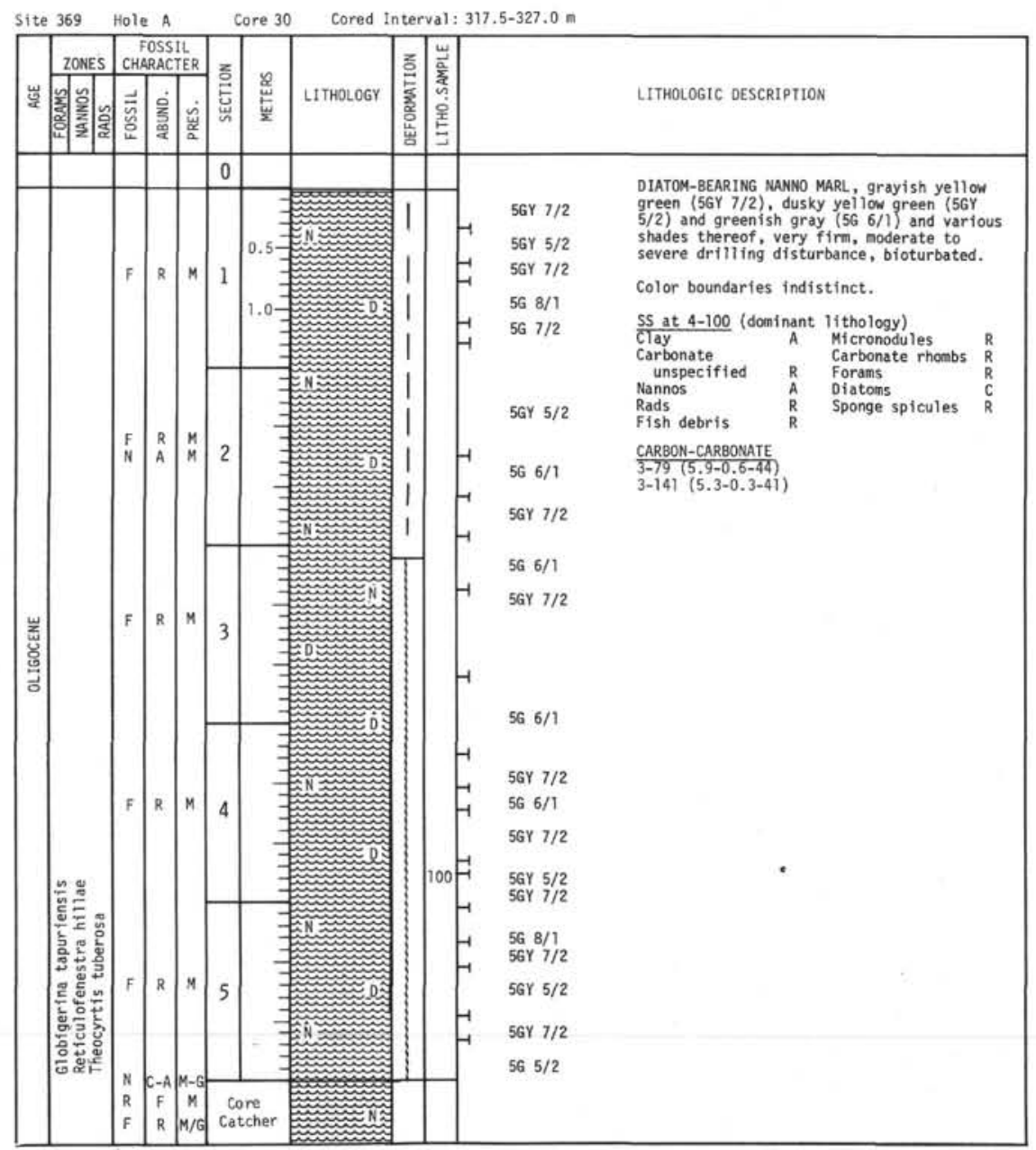

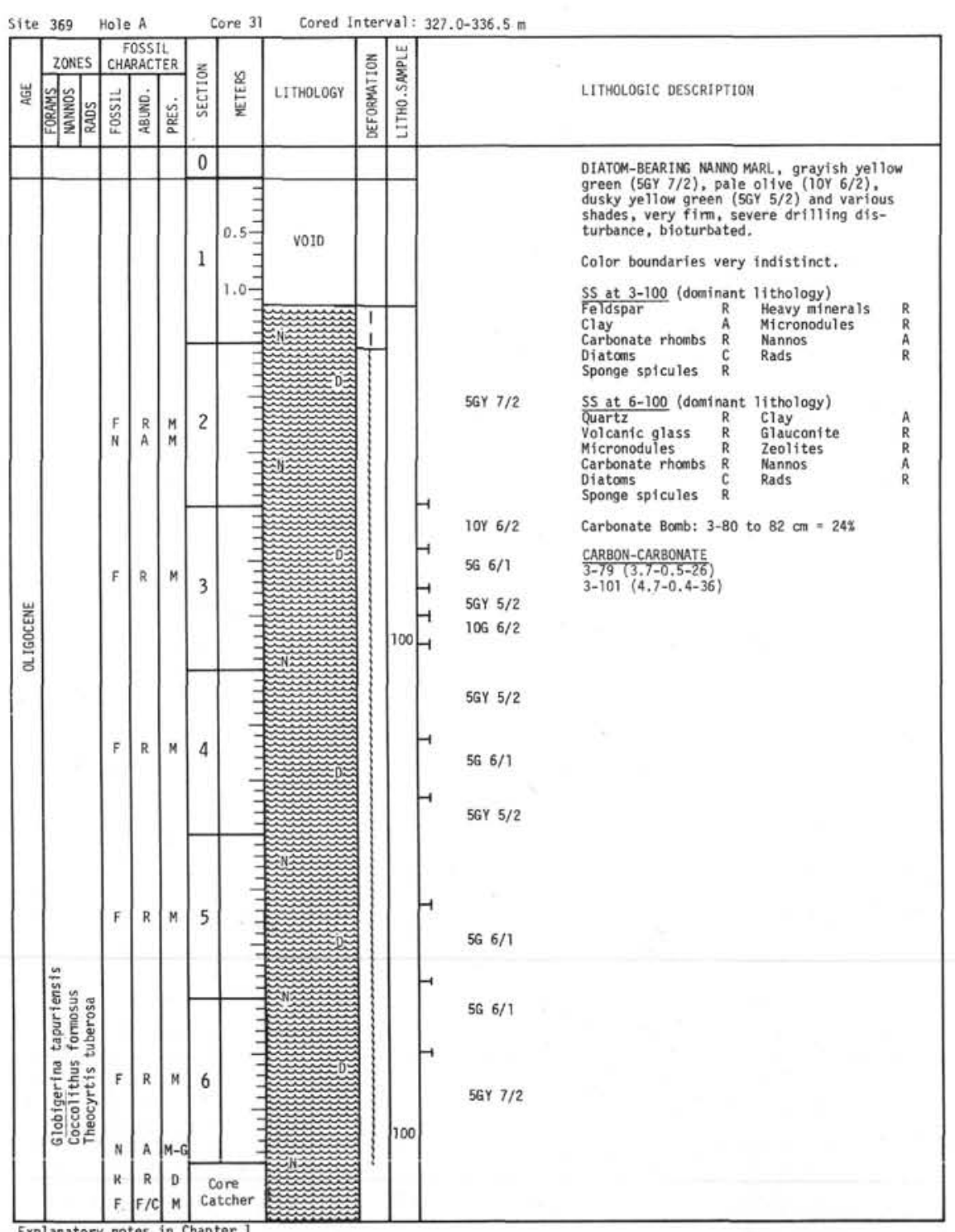




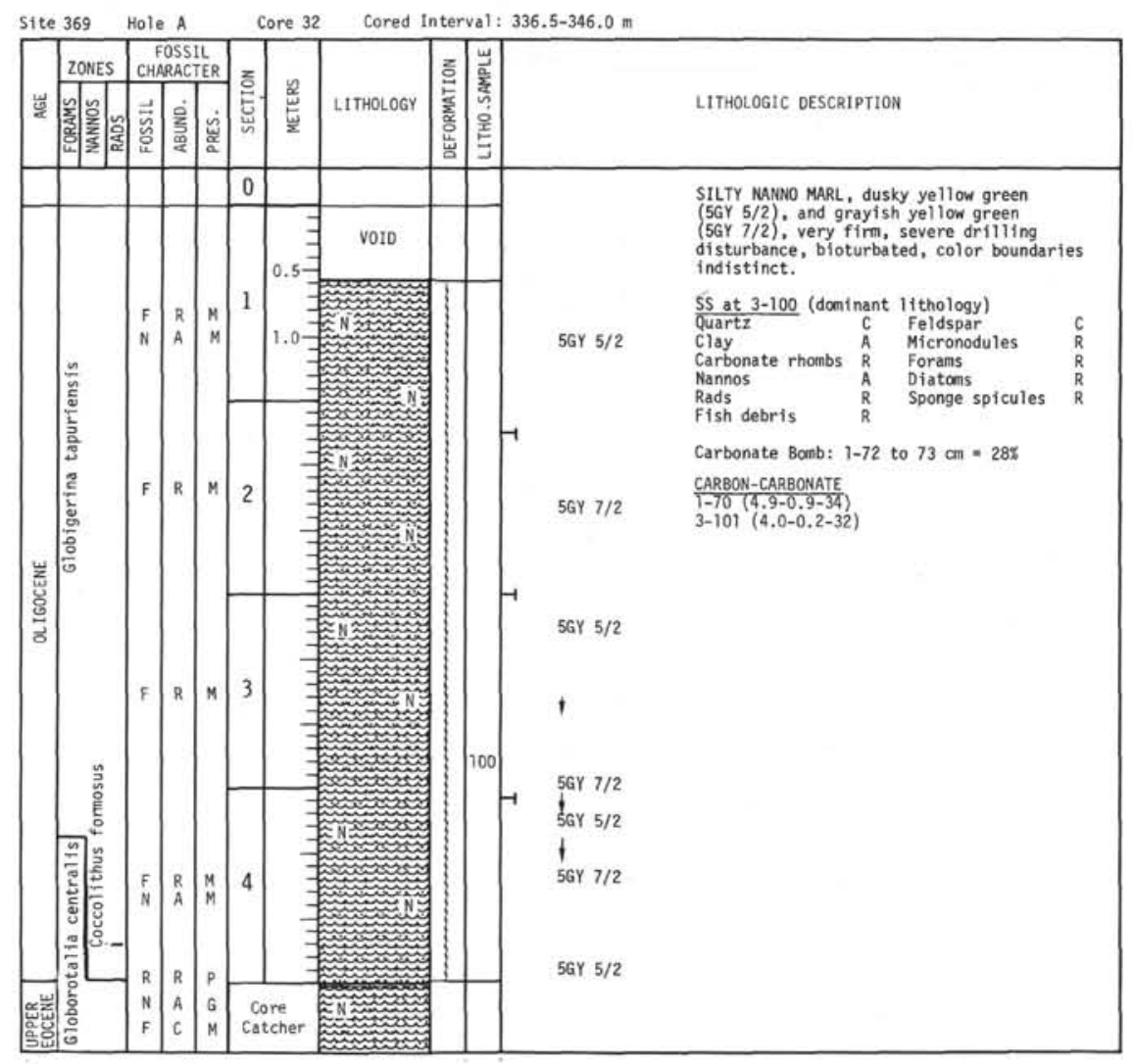

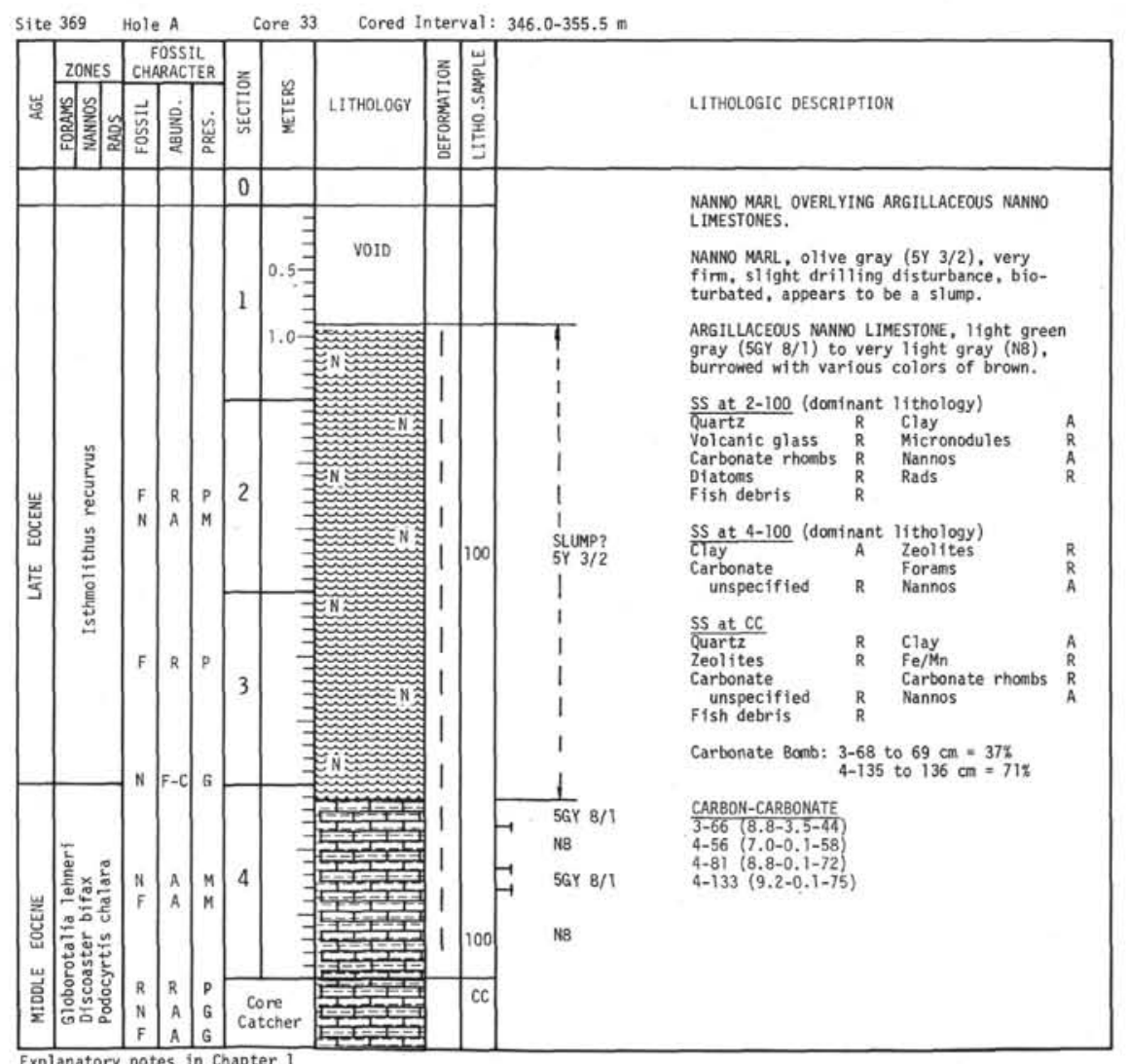



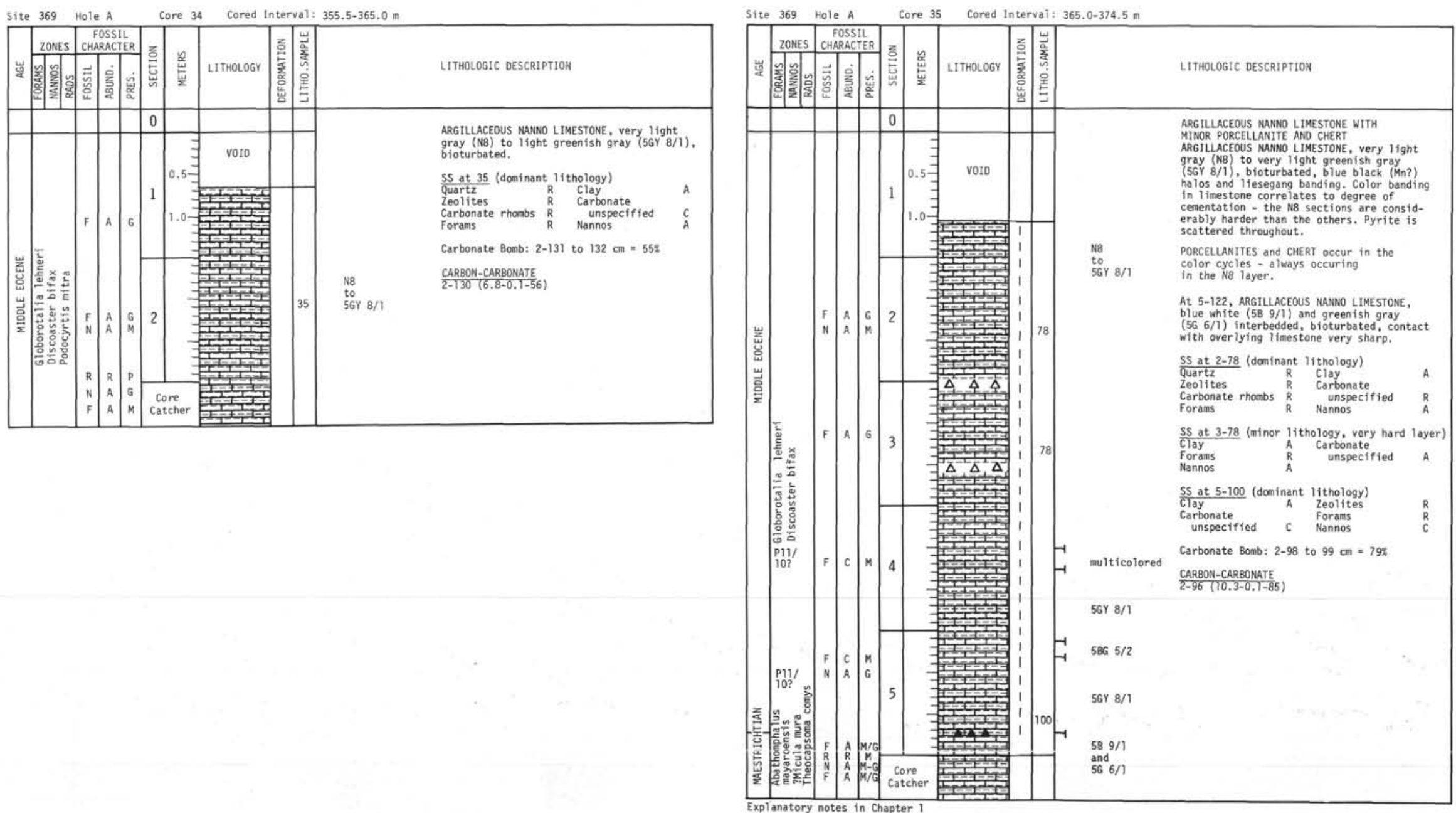

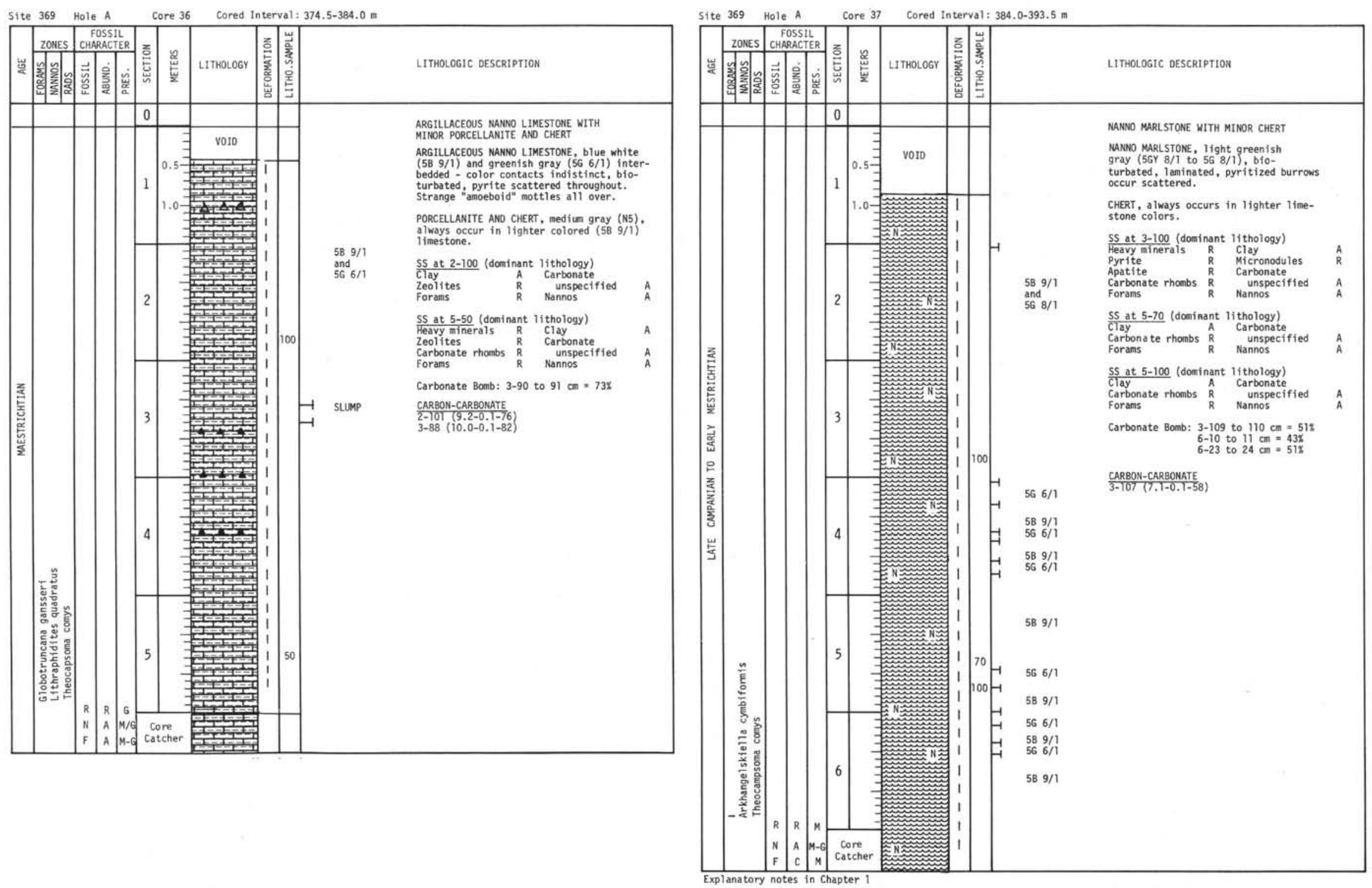

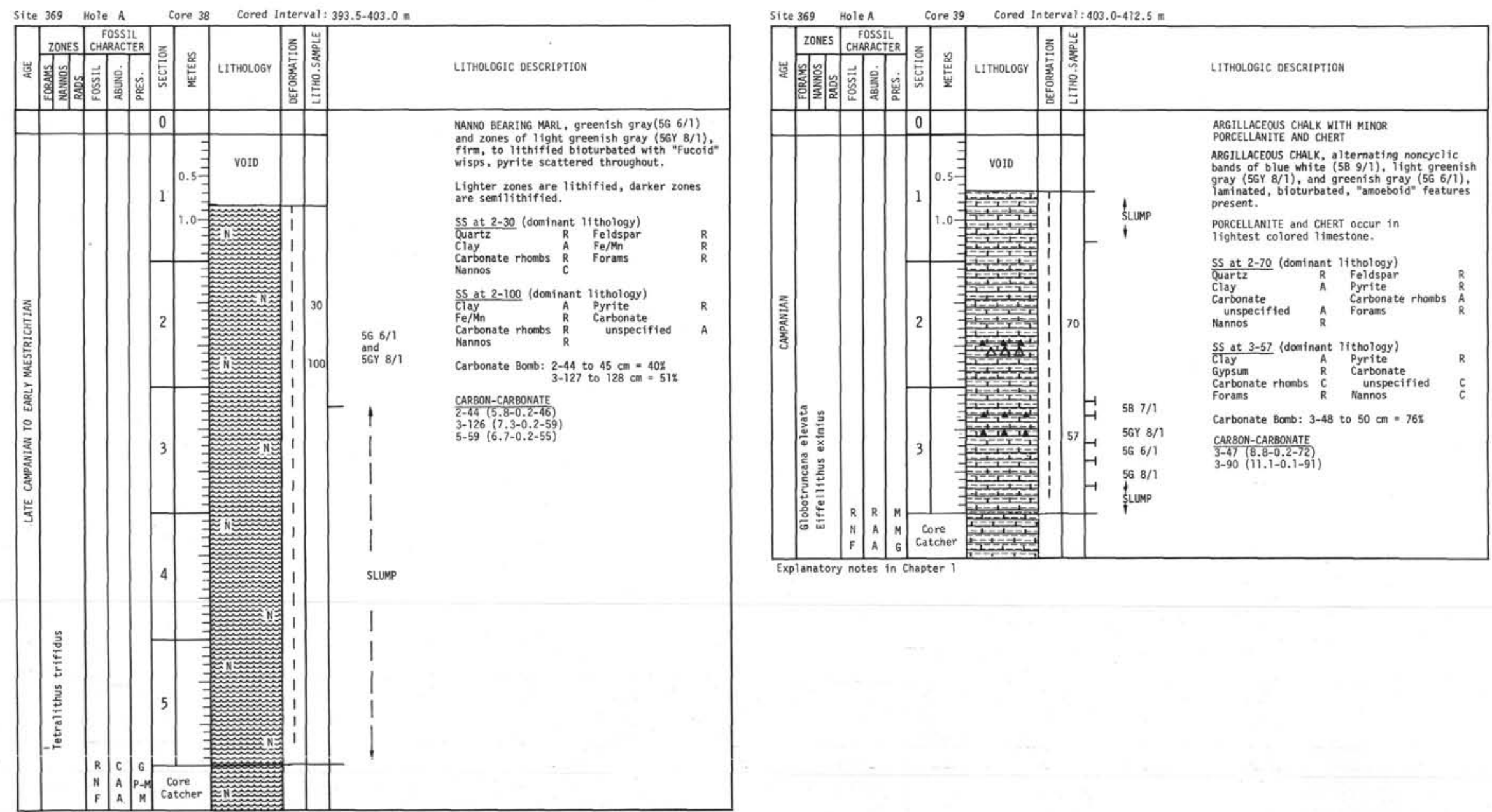

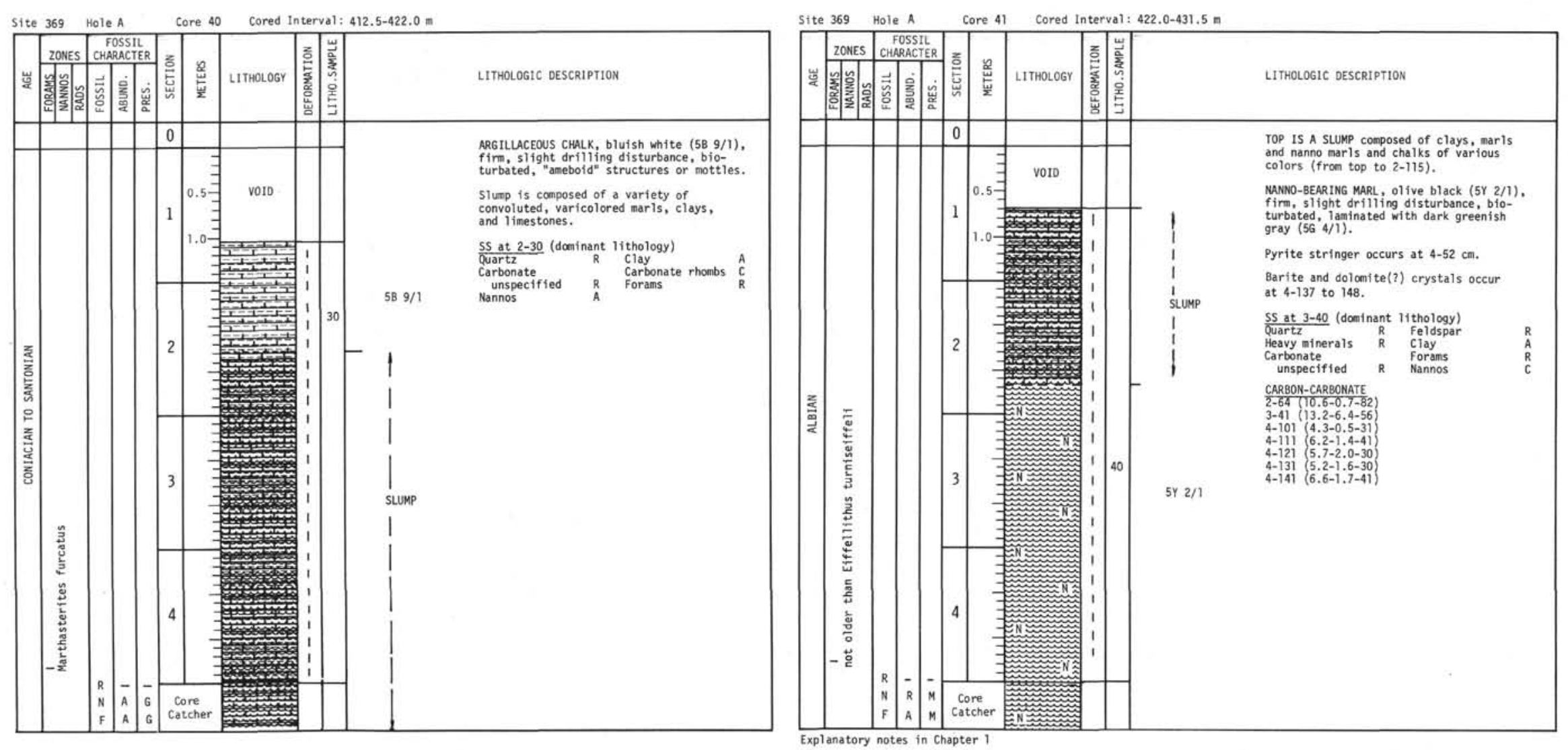


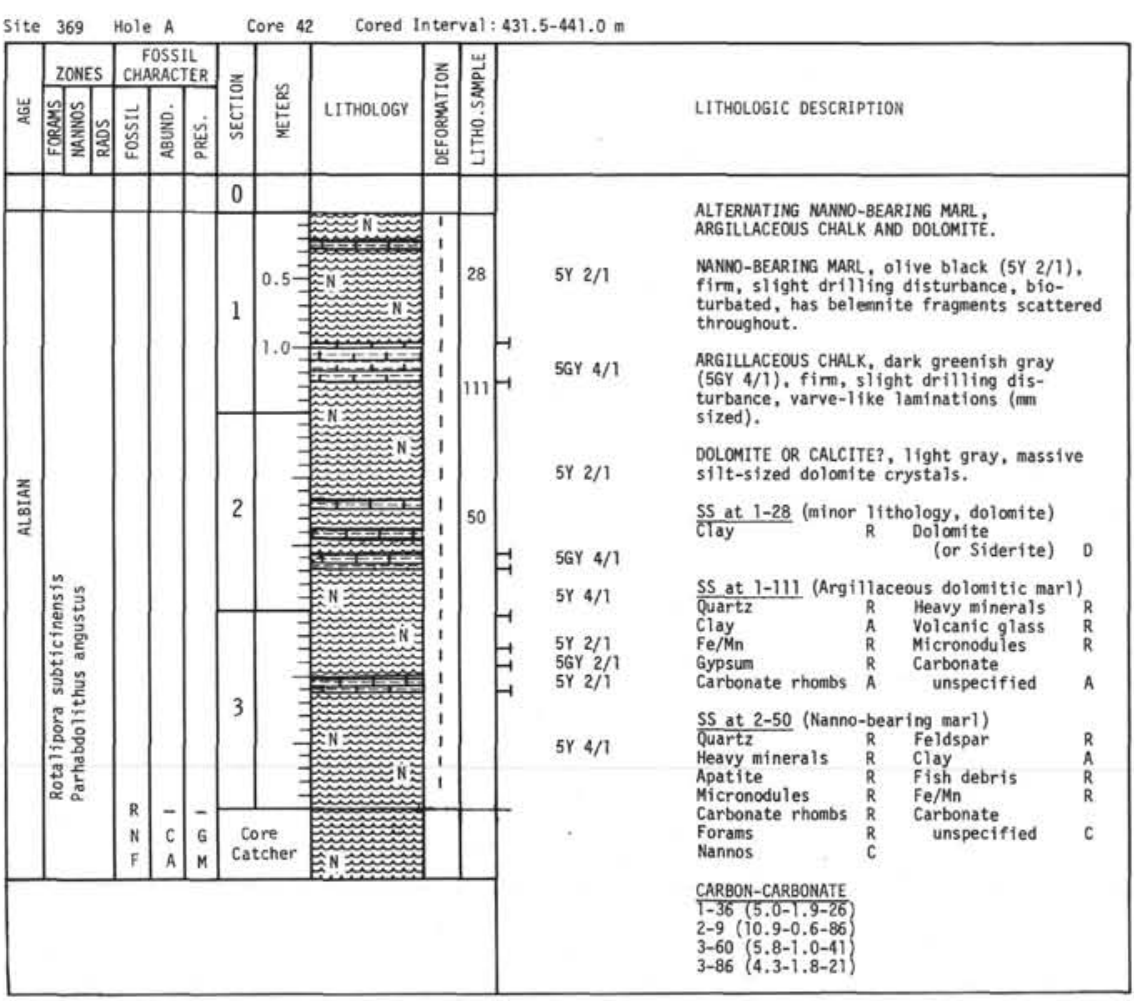

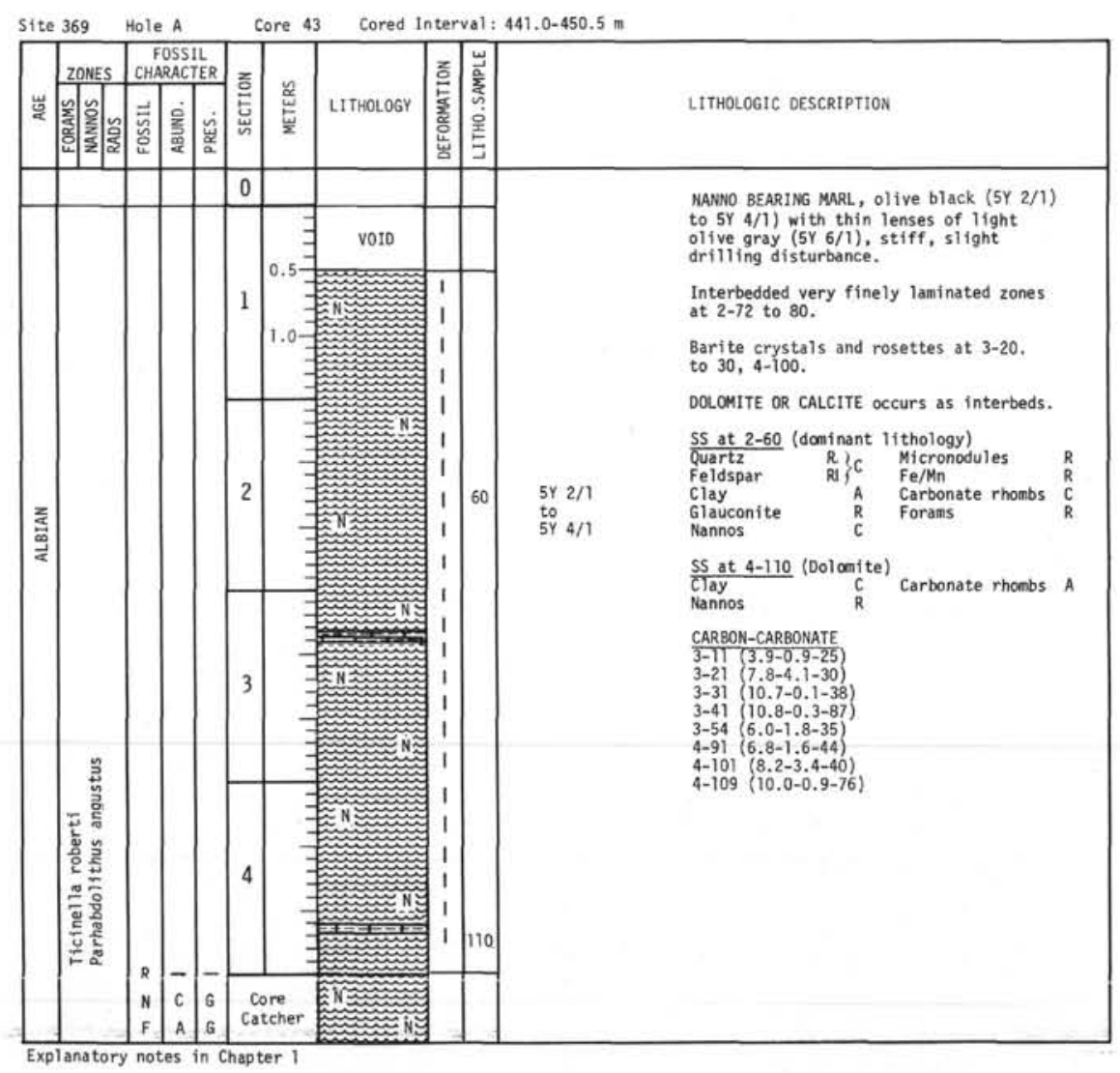

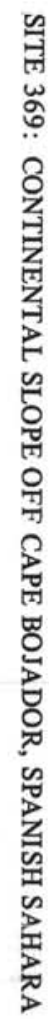




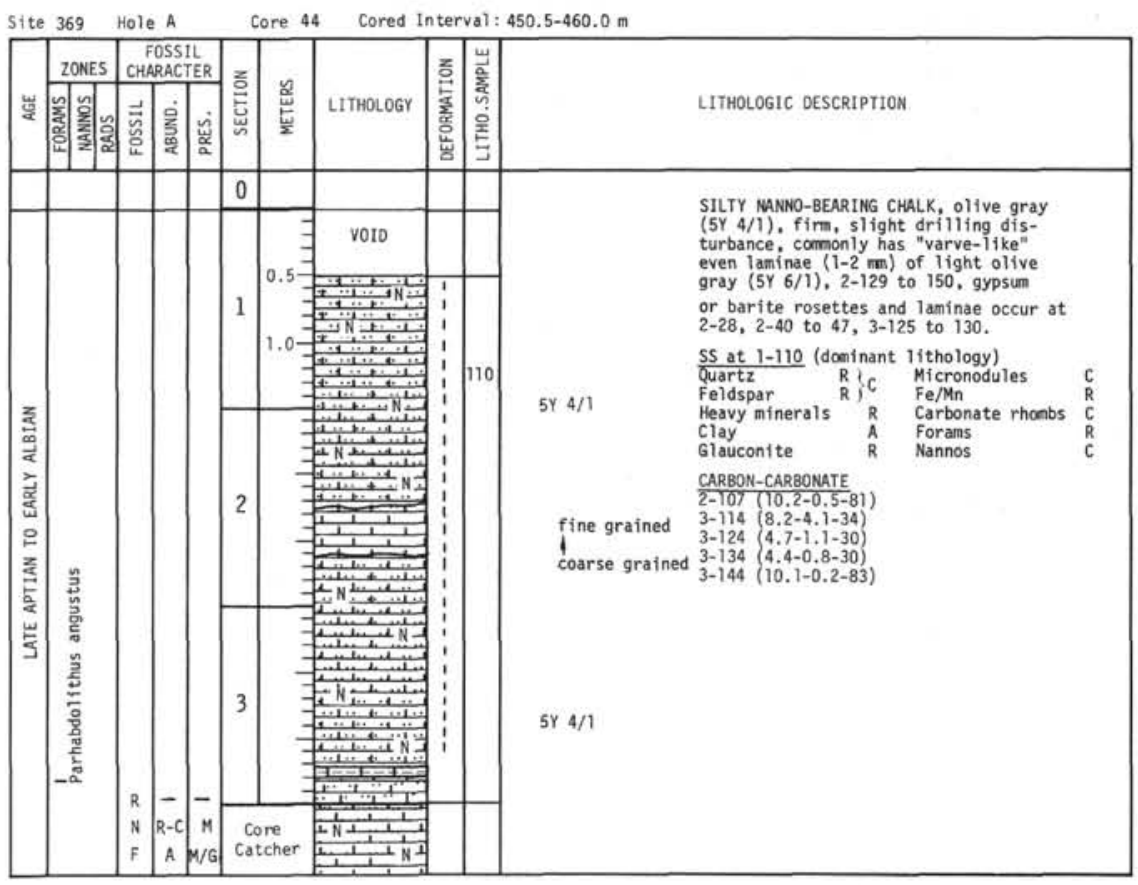

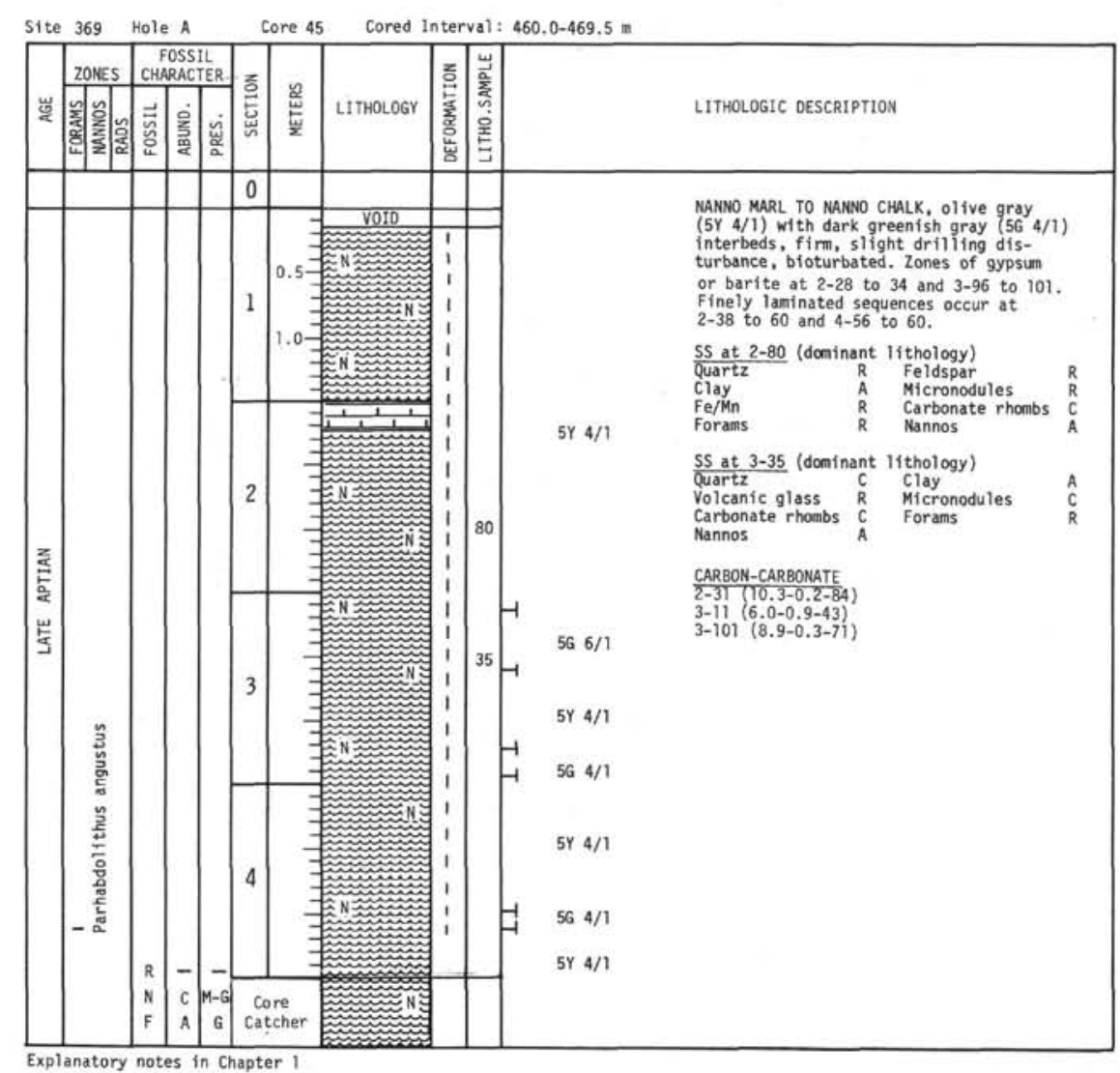




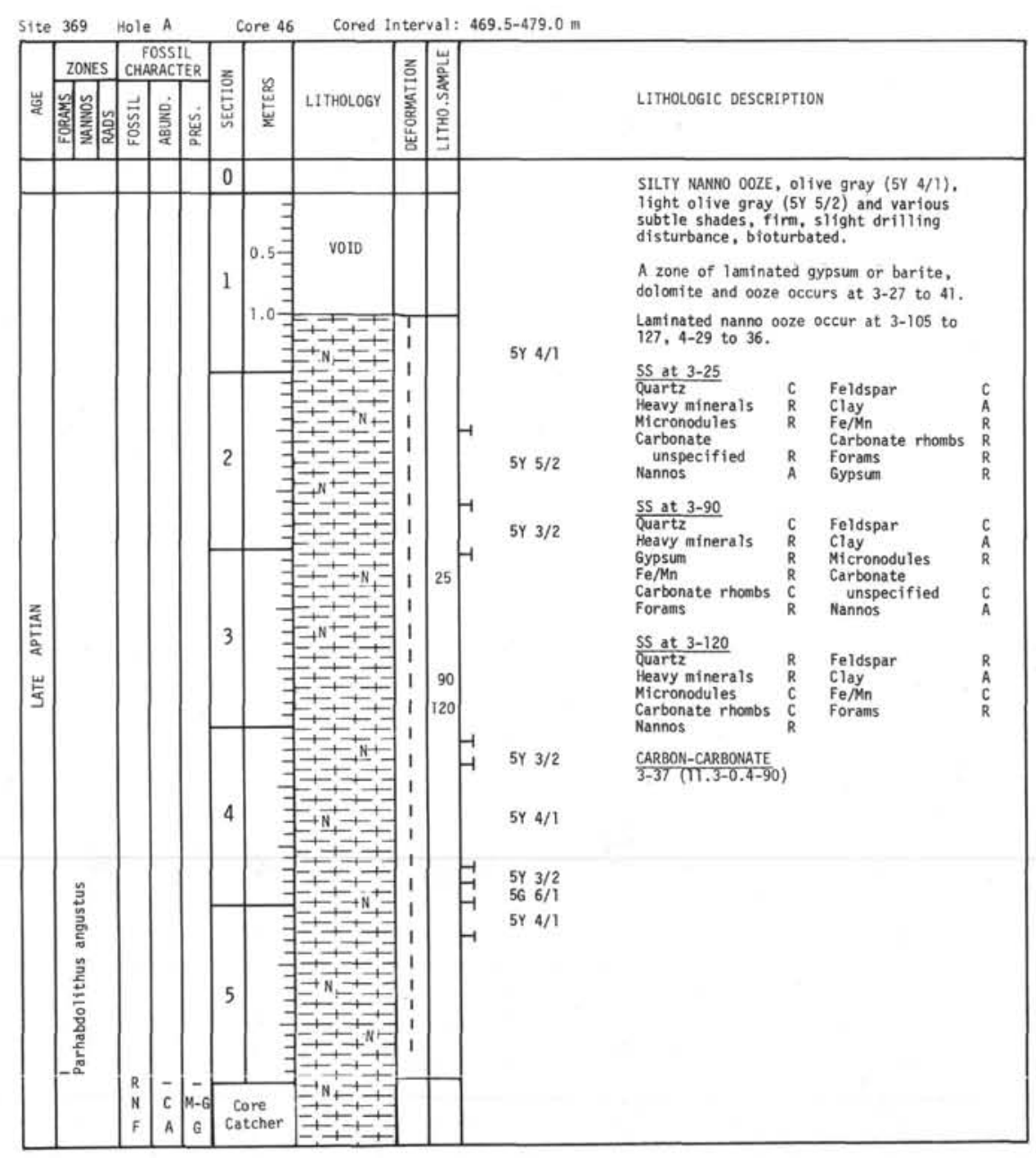

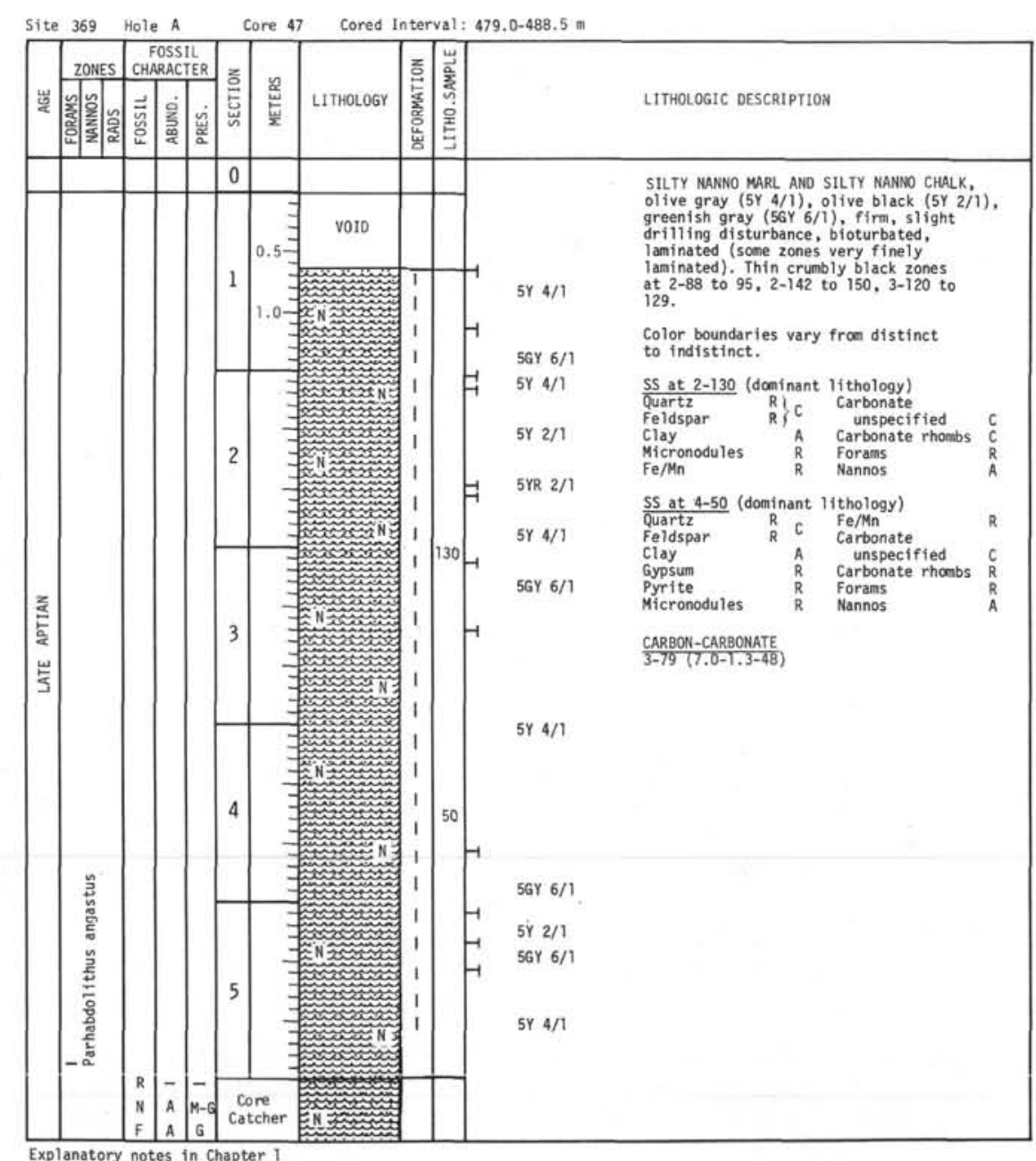


SITE 369: CONTINENTAL SLOPE OFF CAPE BOJADOR, SPANISH SAHARA

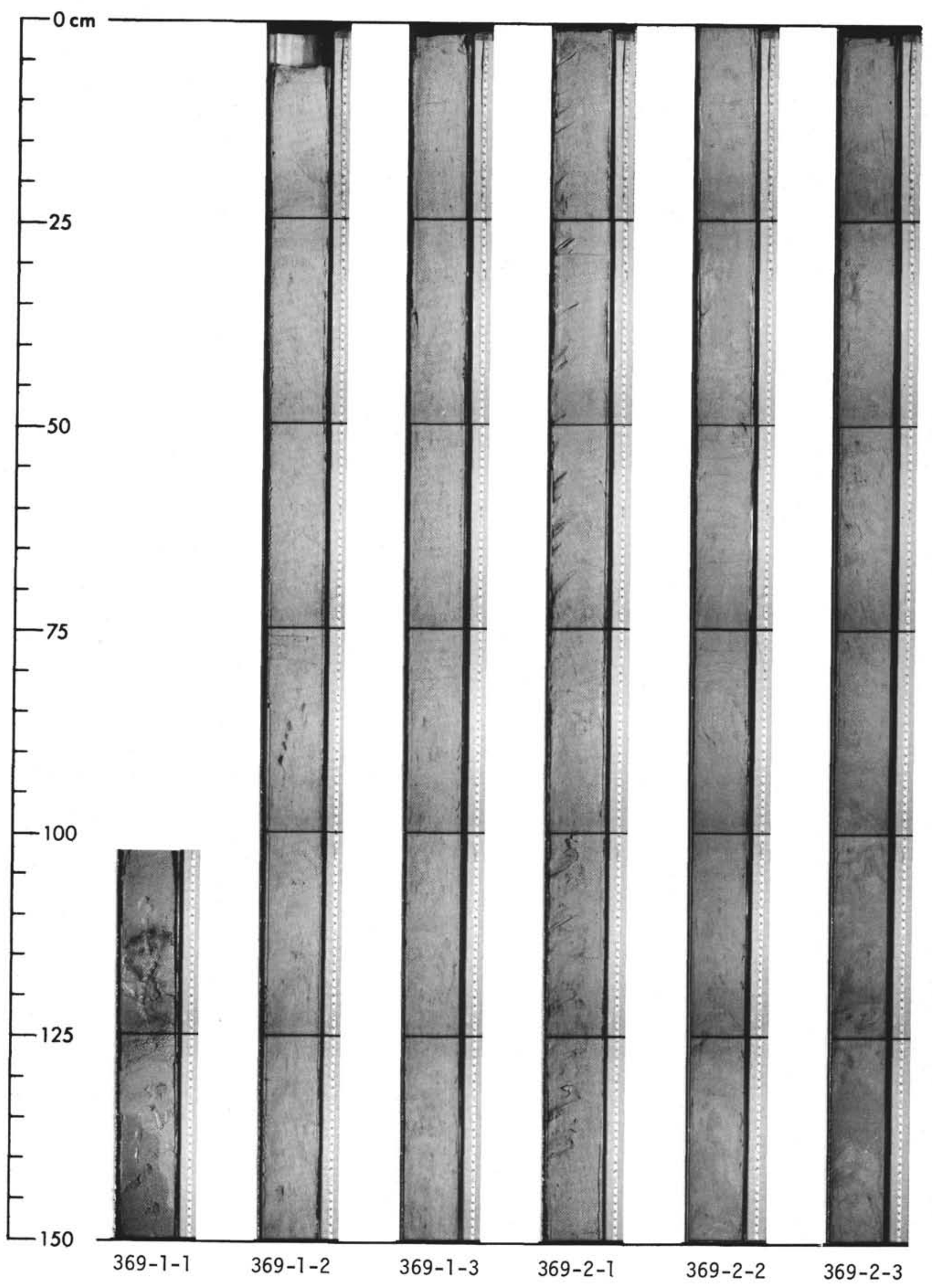




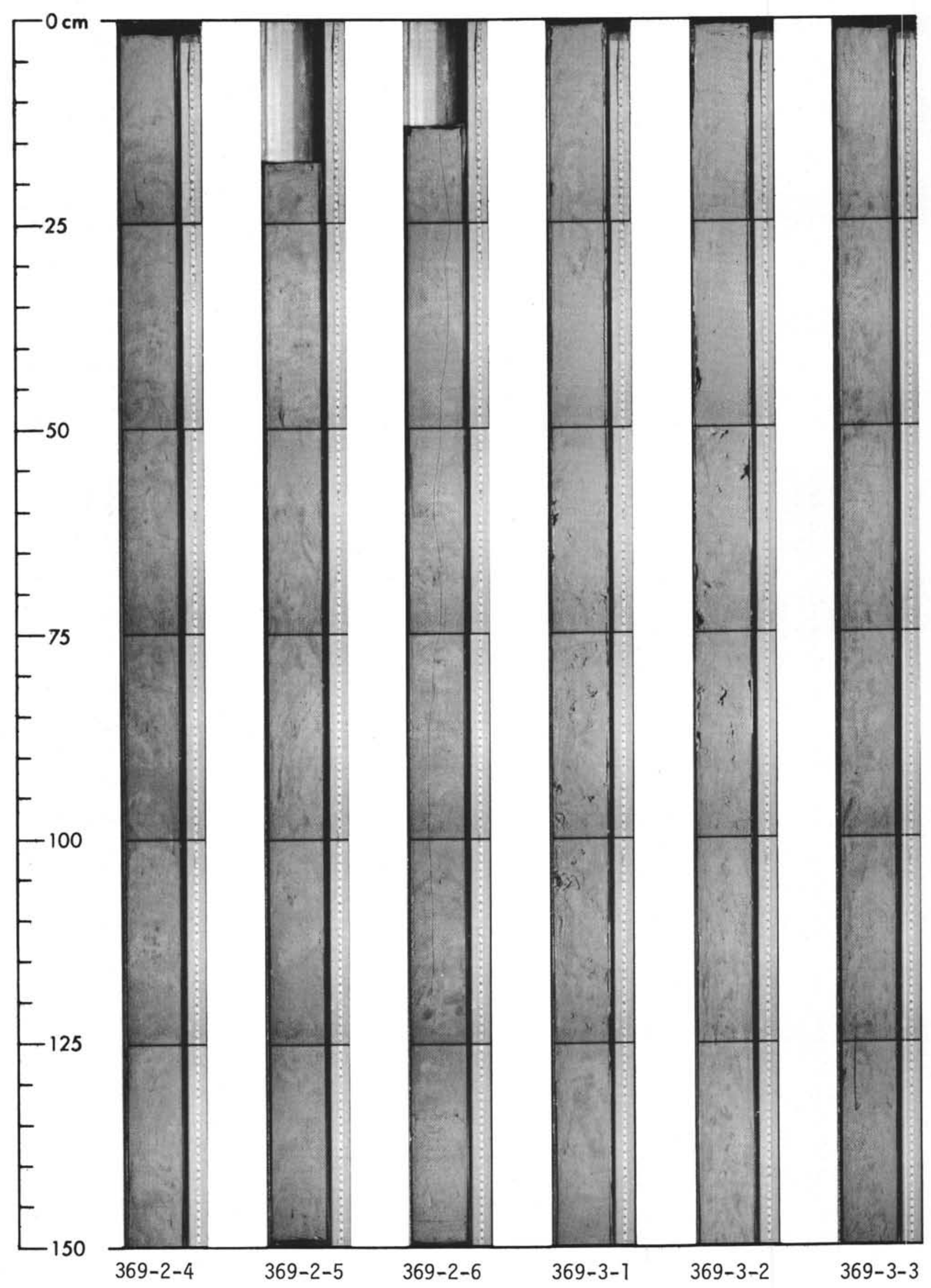




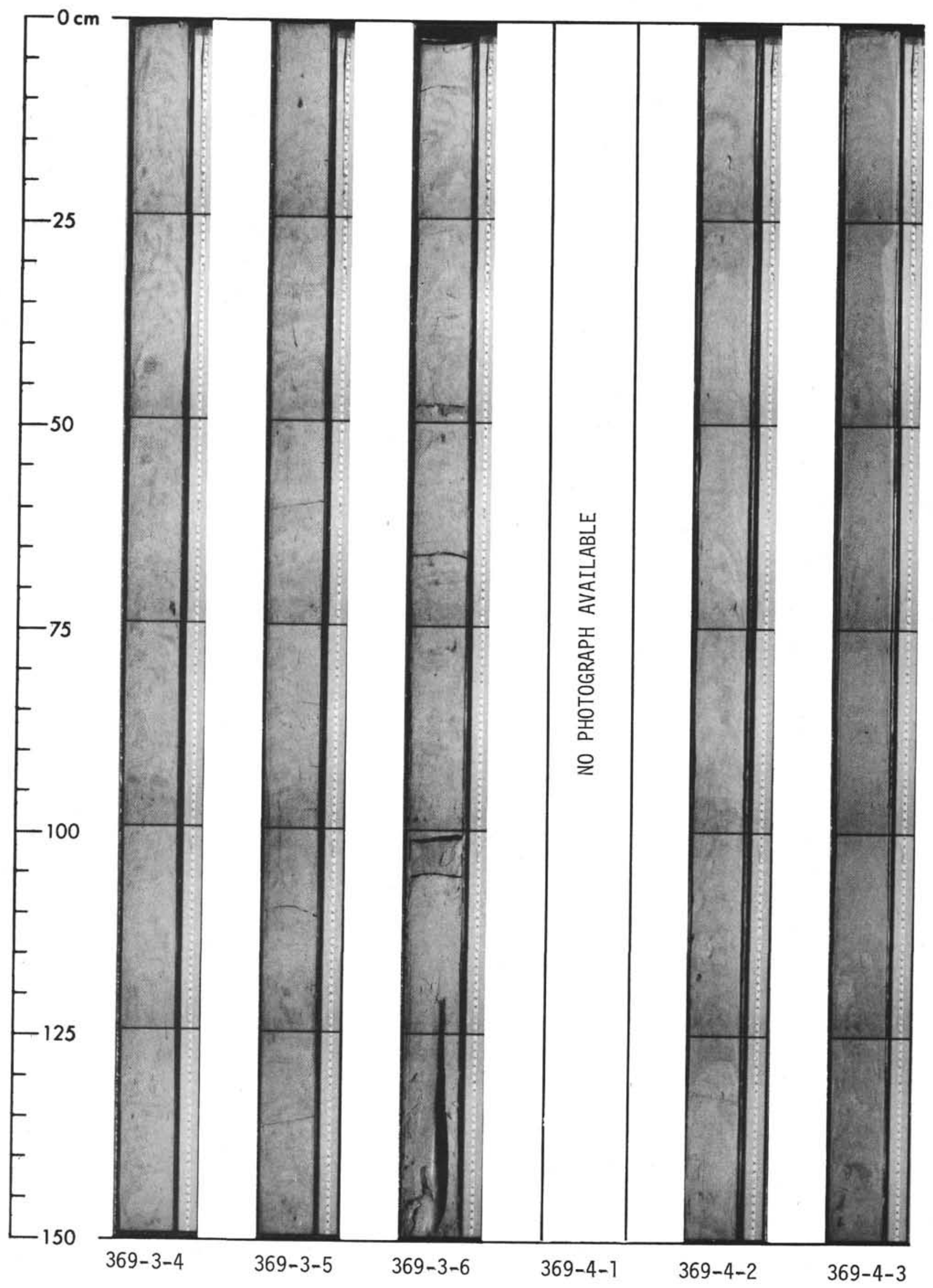


SITE 369: CONTINENTAL SLOPE OFF CAPE BOJADOR, SPANISH SAHARA

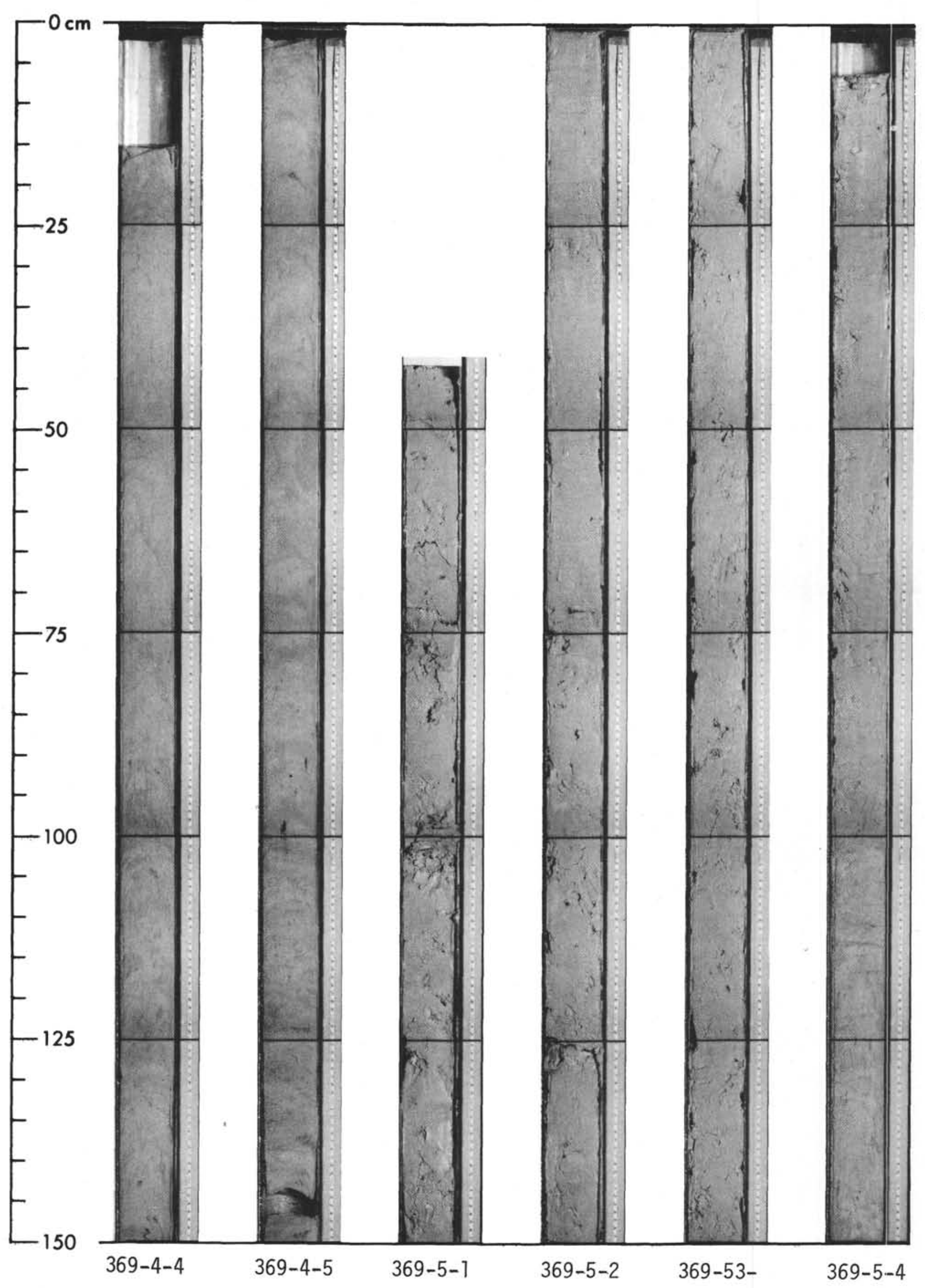


SITE 369: CONTINENTAL SLOPE OFF CAPE BOJADOR, SPANISH SAHARA

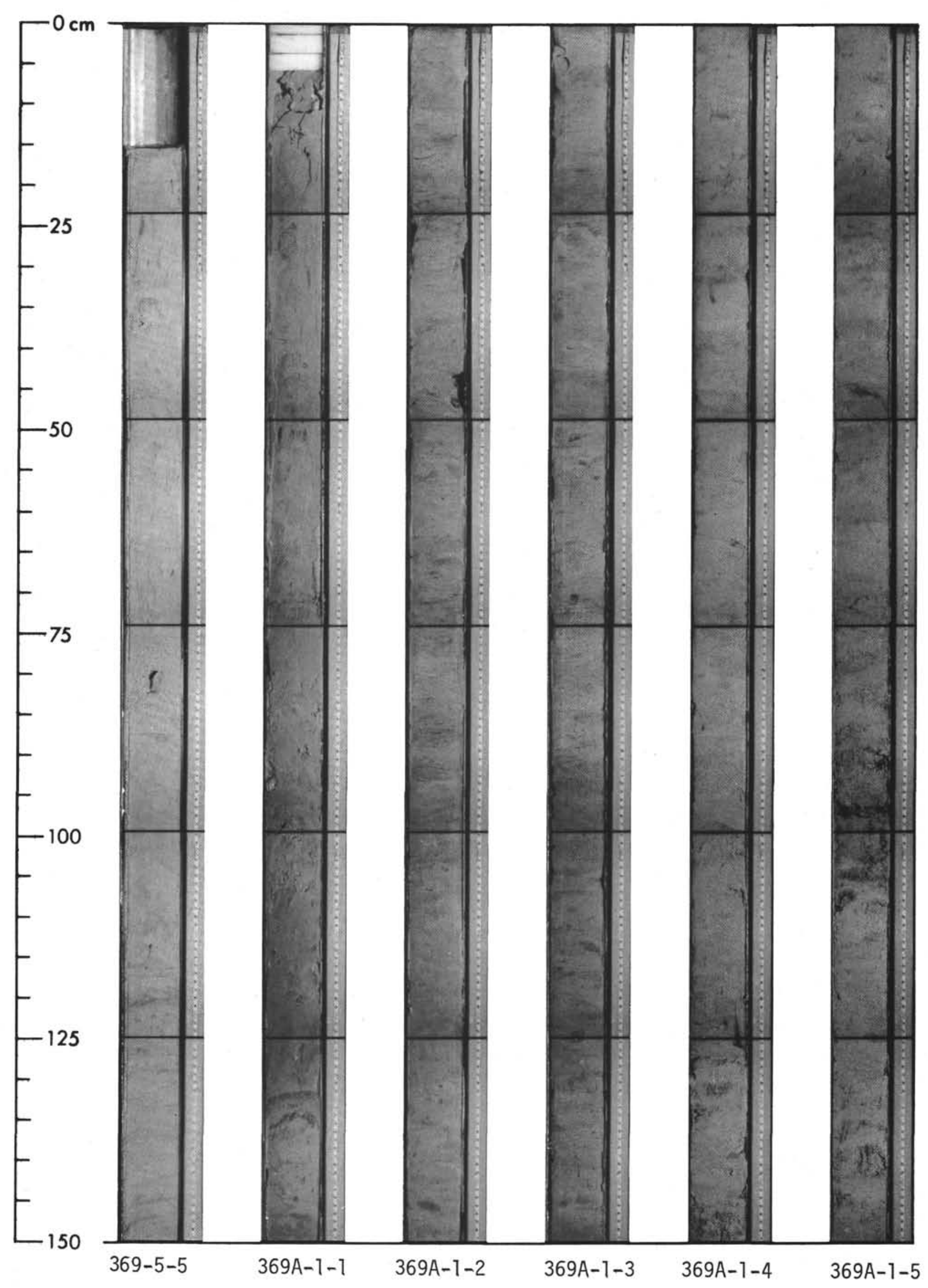




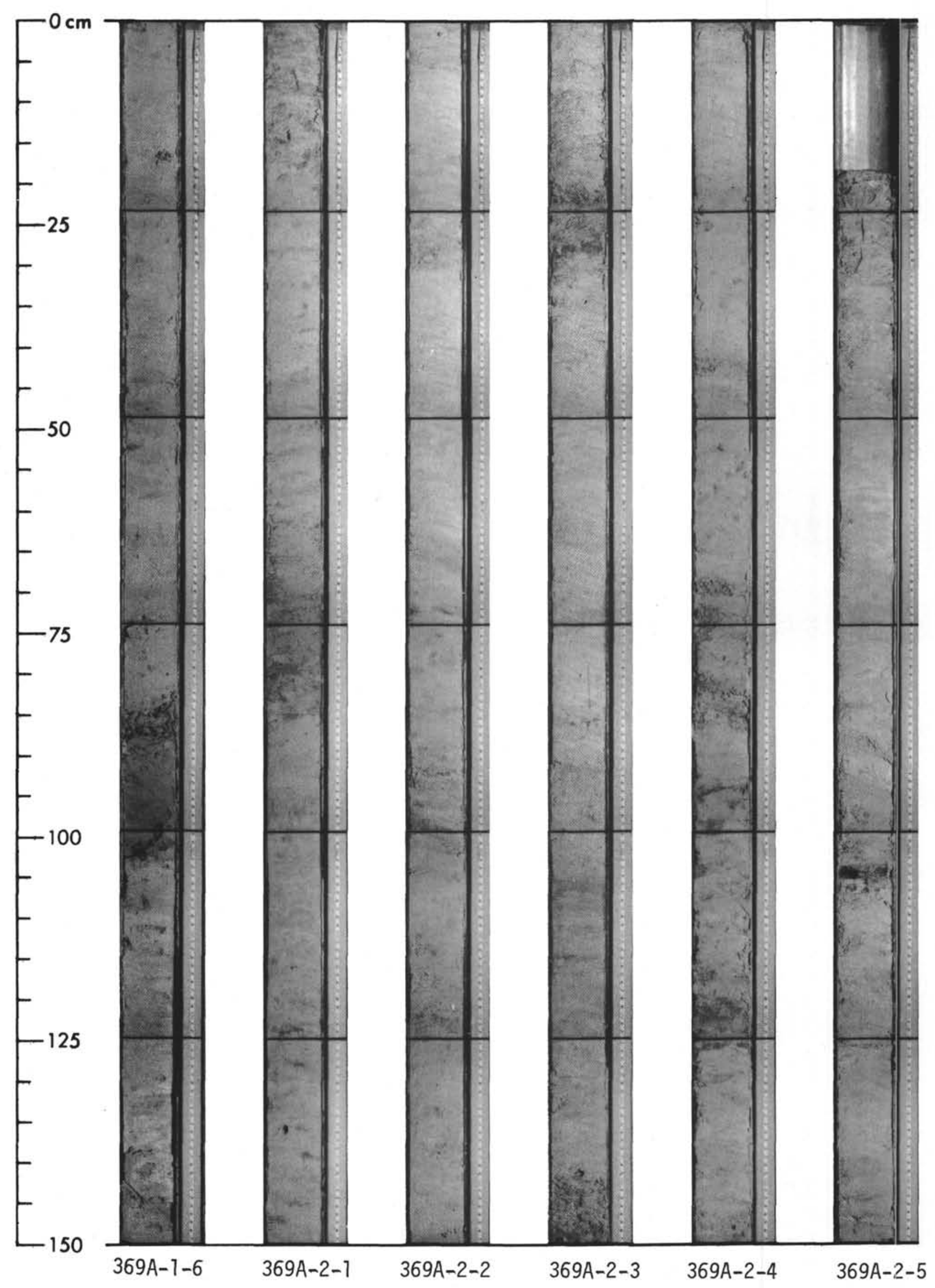




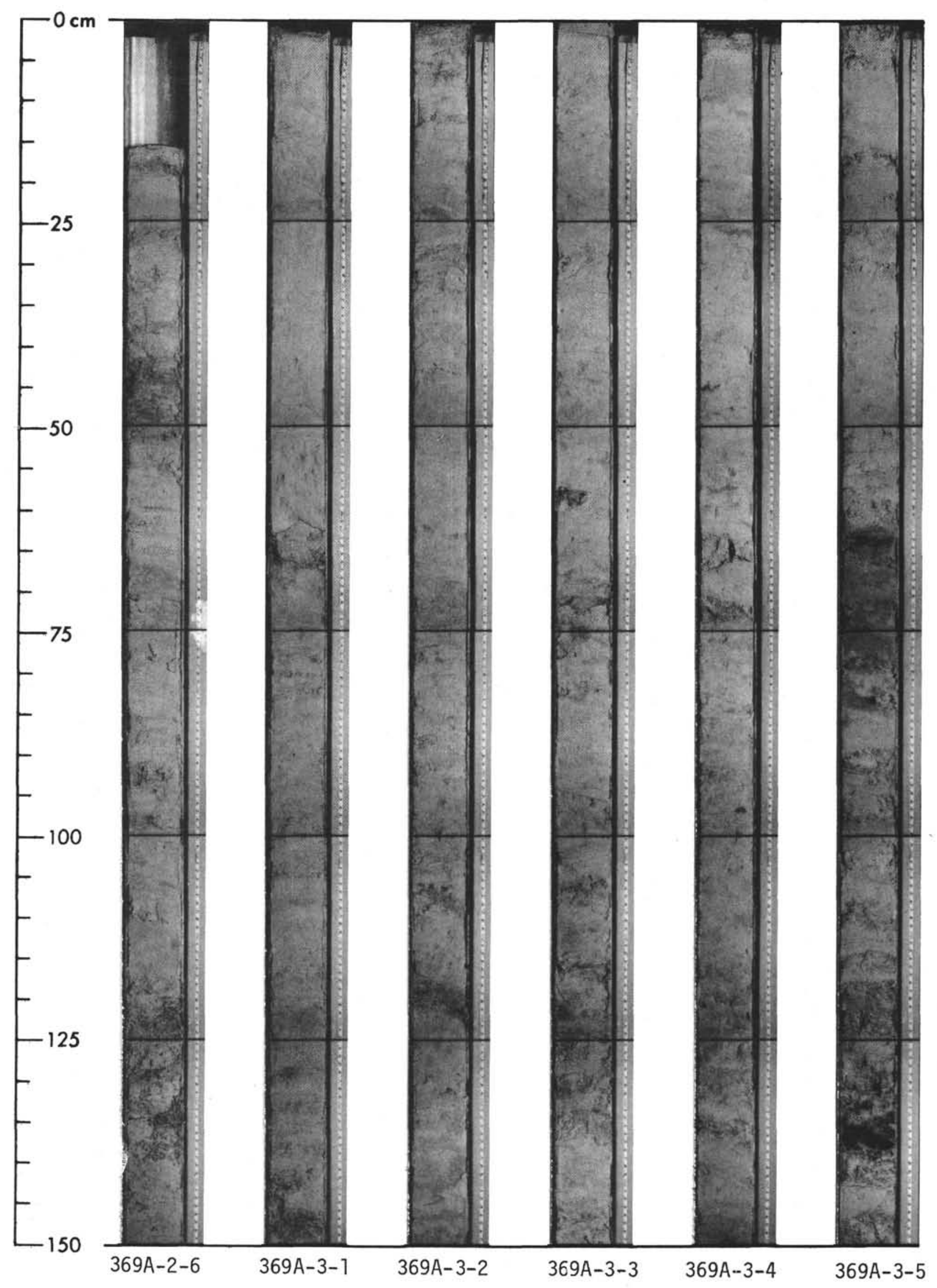




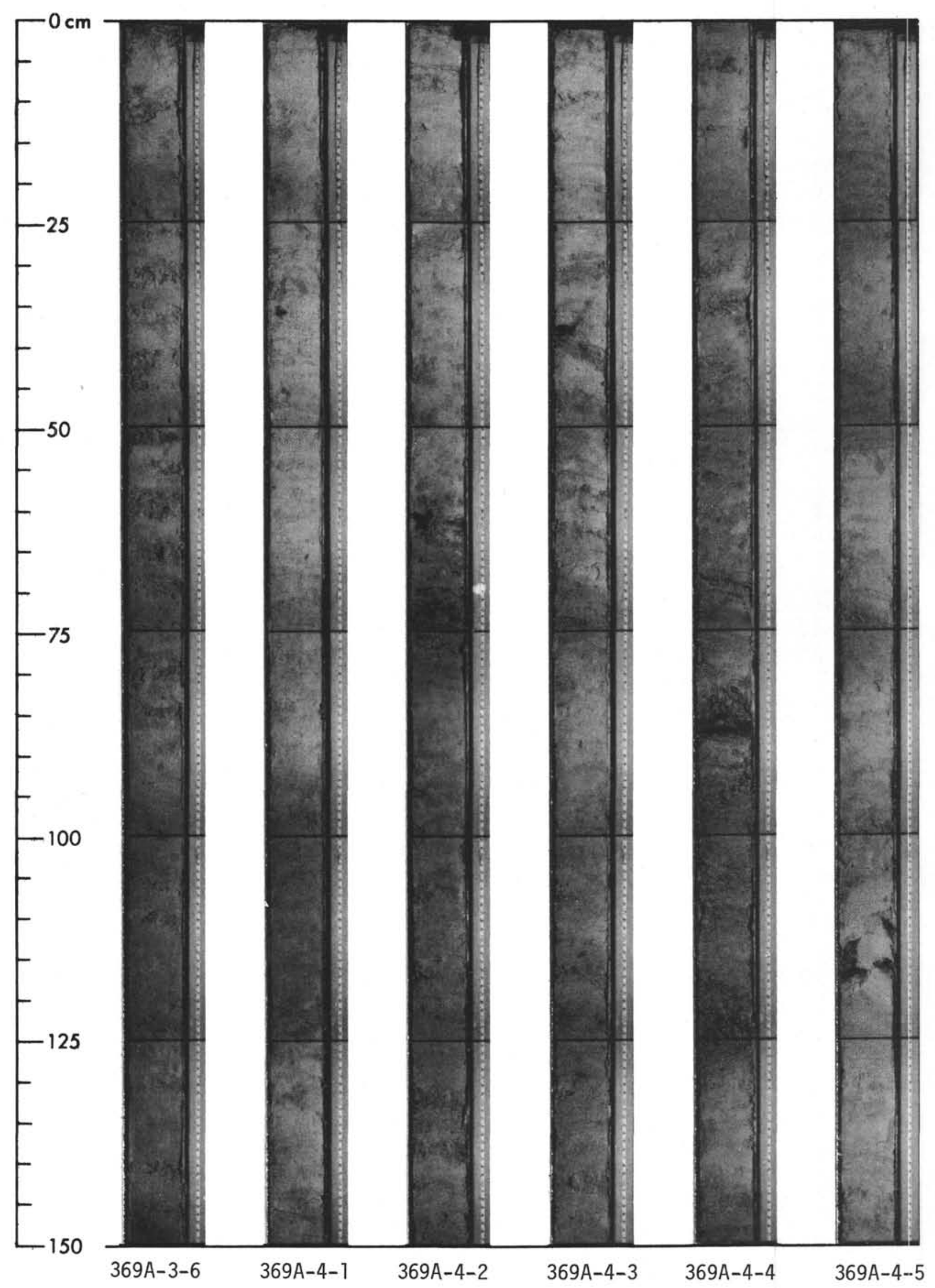




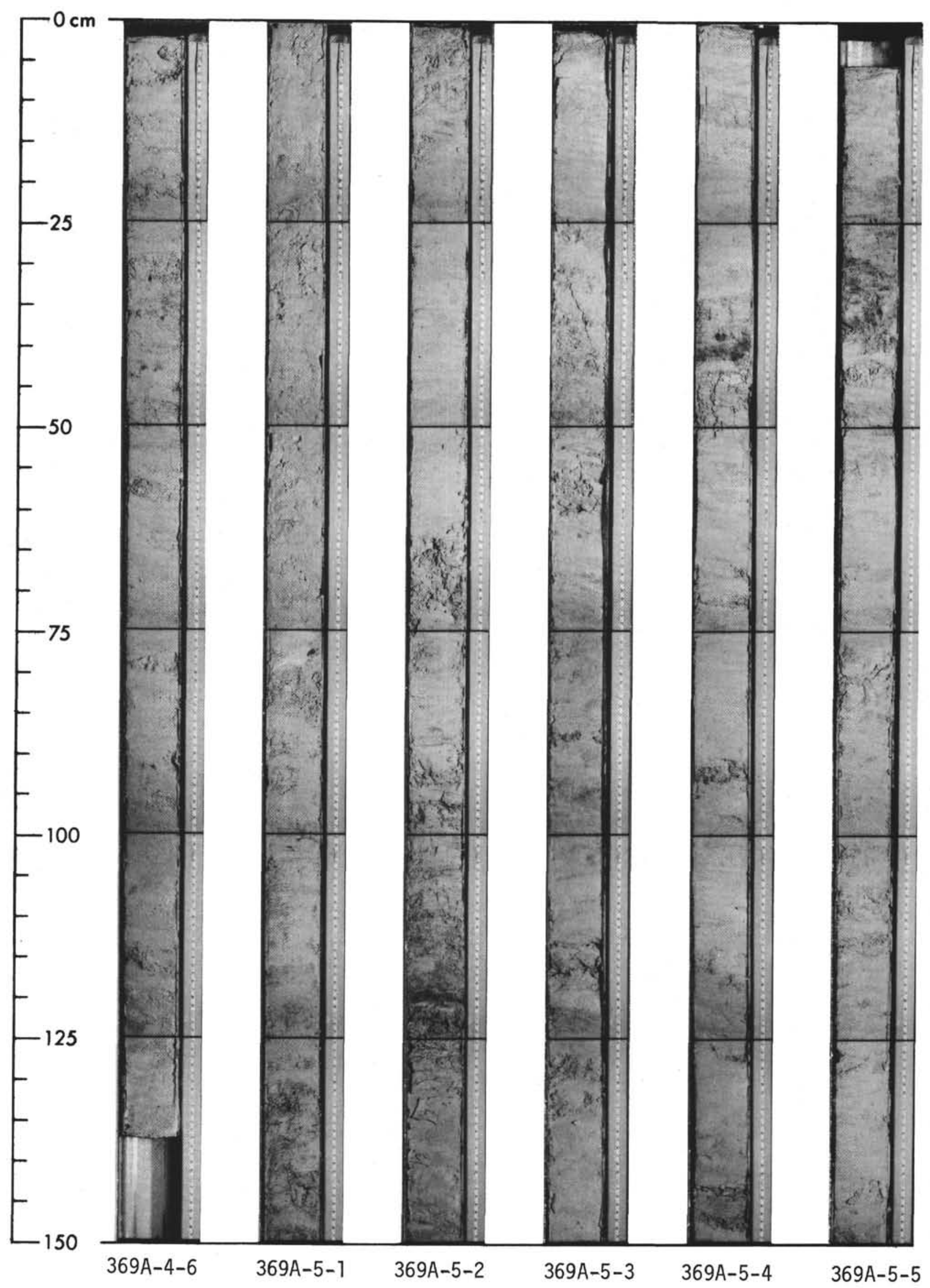


SITE 369: CONTINENTAL SLOPE OFF CAPE BOJADOR, SPANISH SAHARA

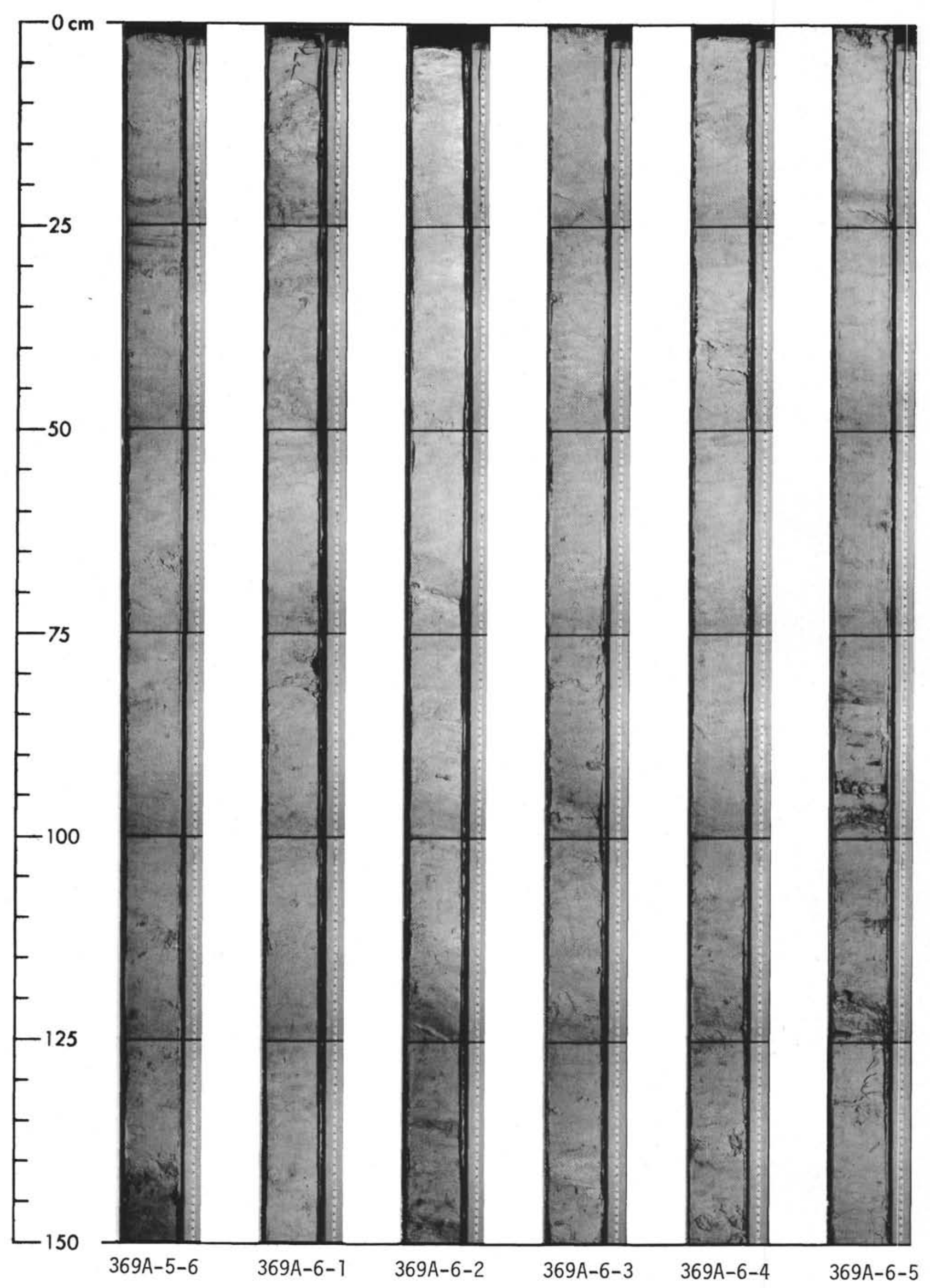




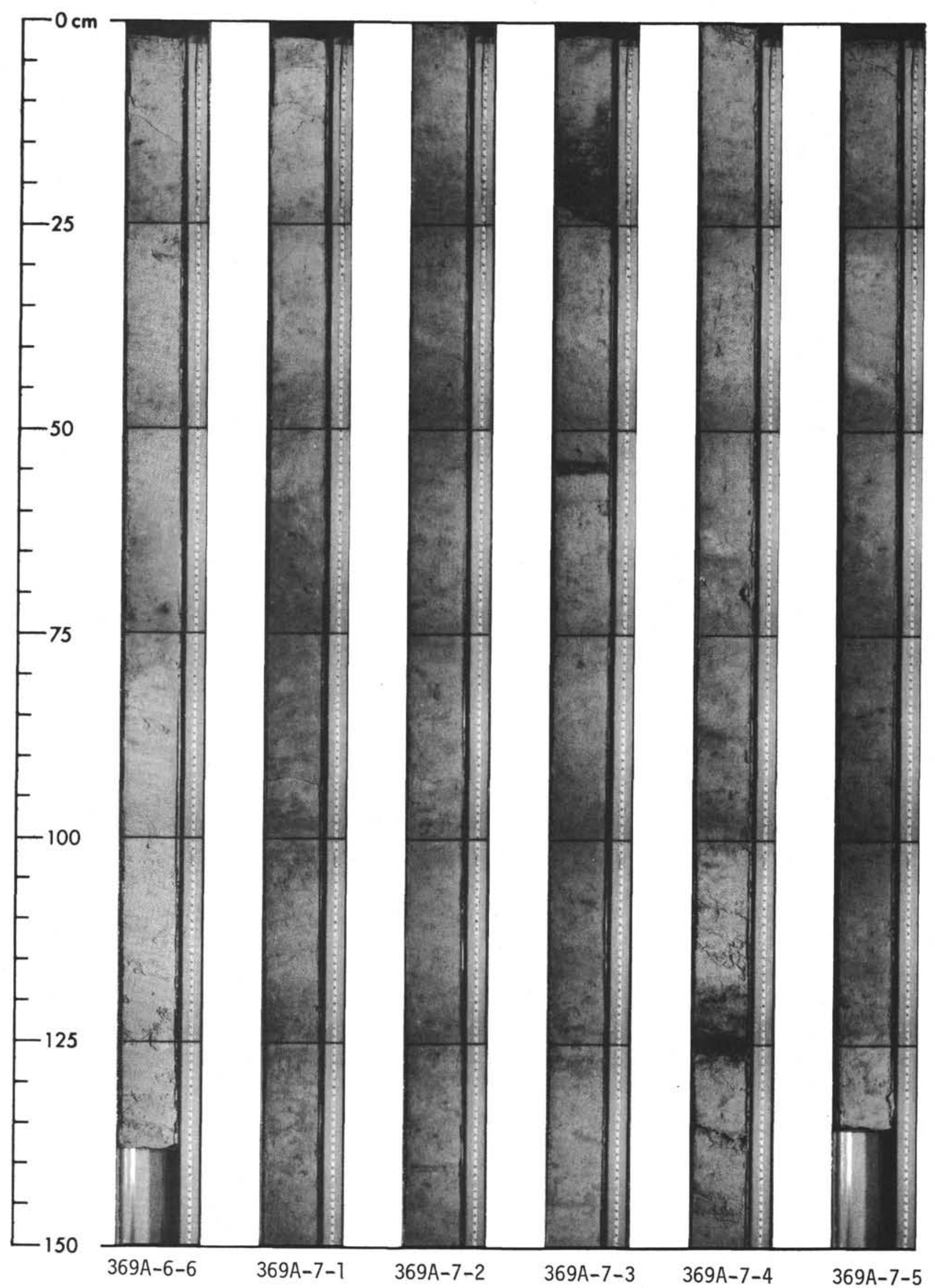




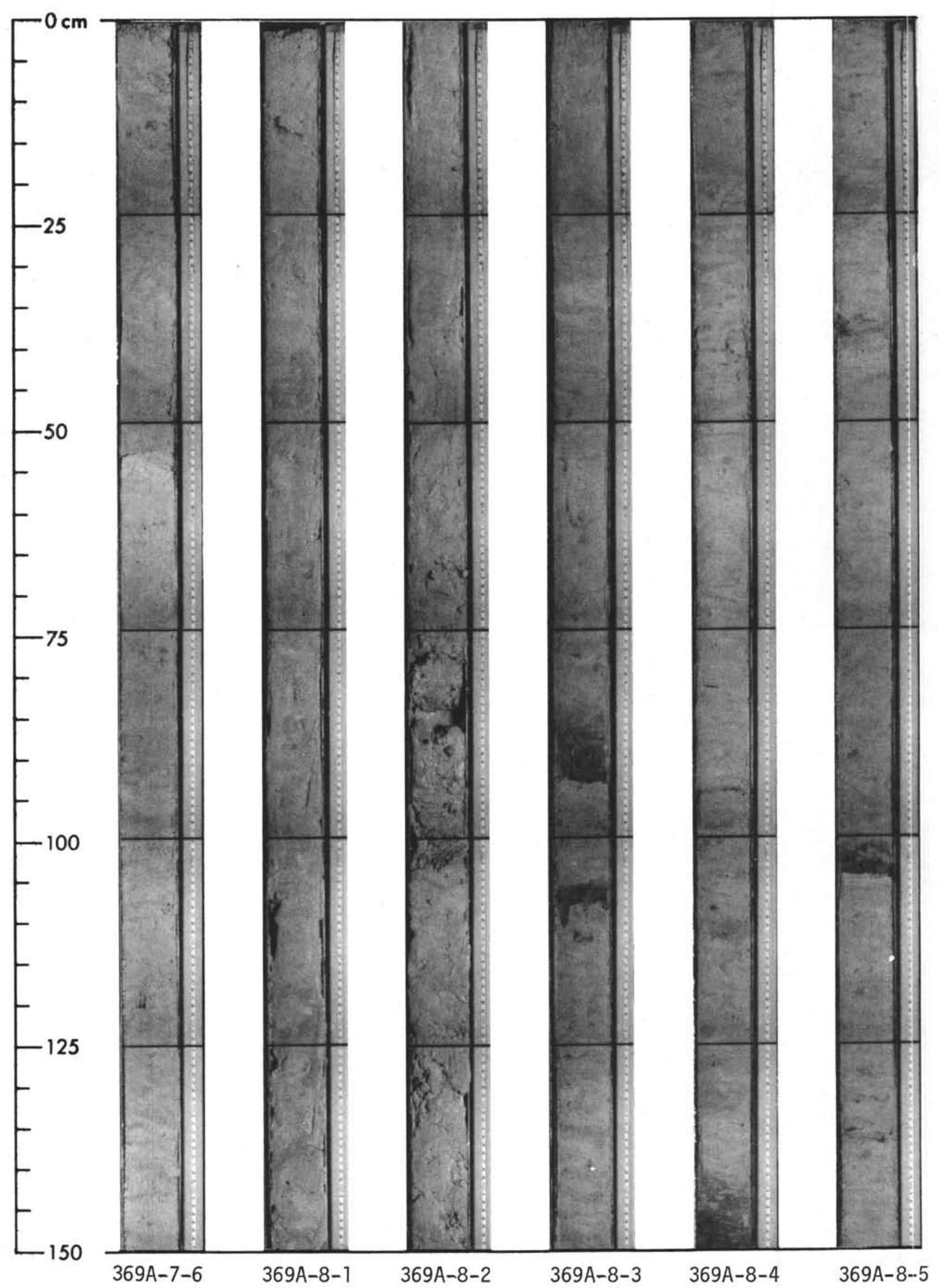




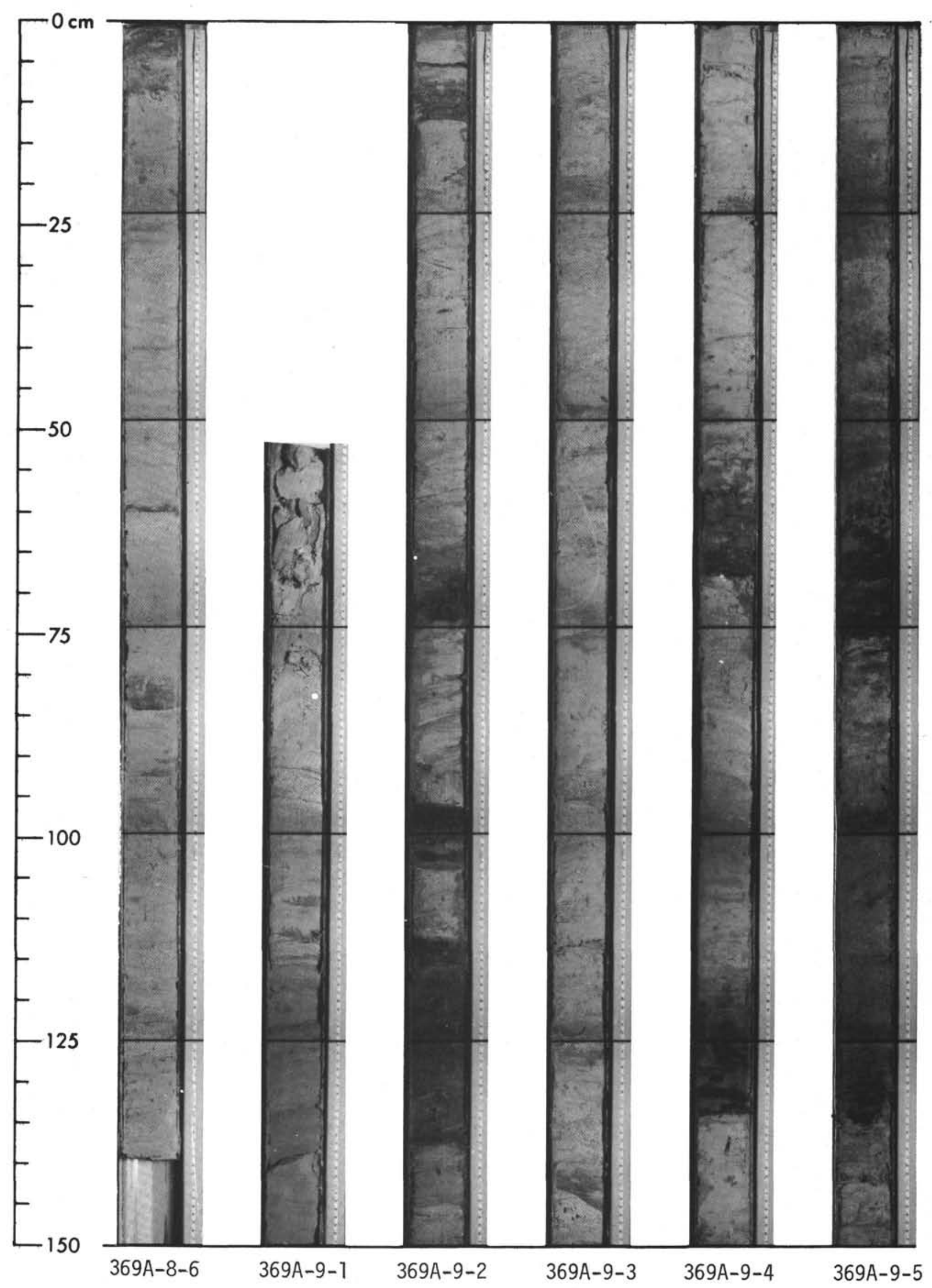




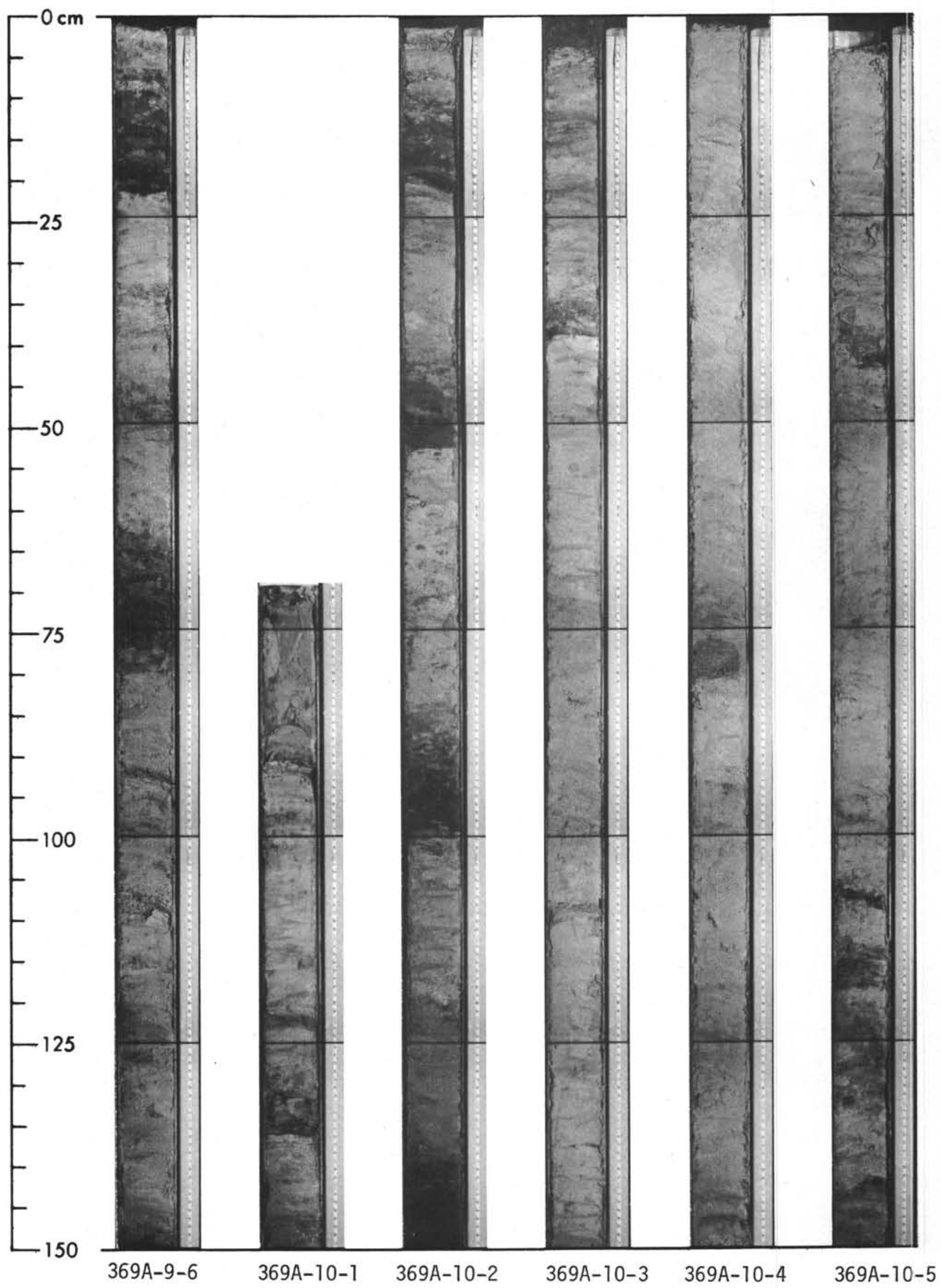




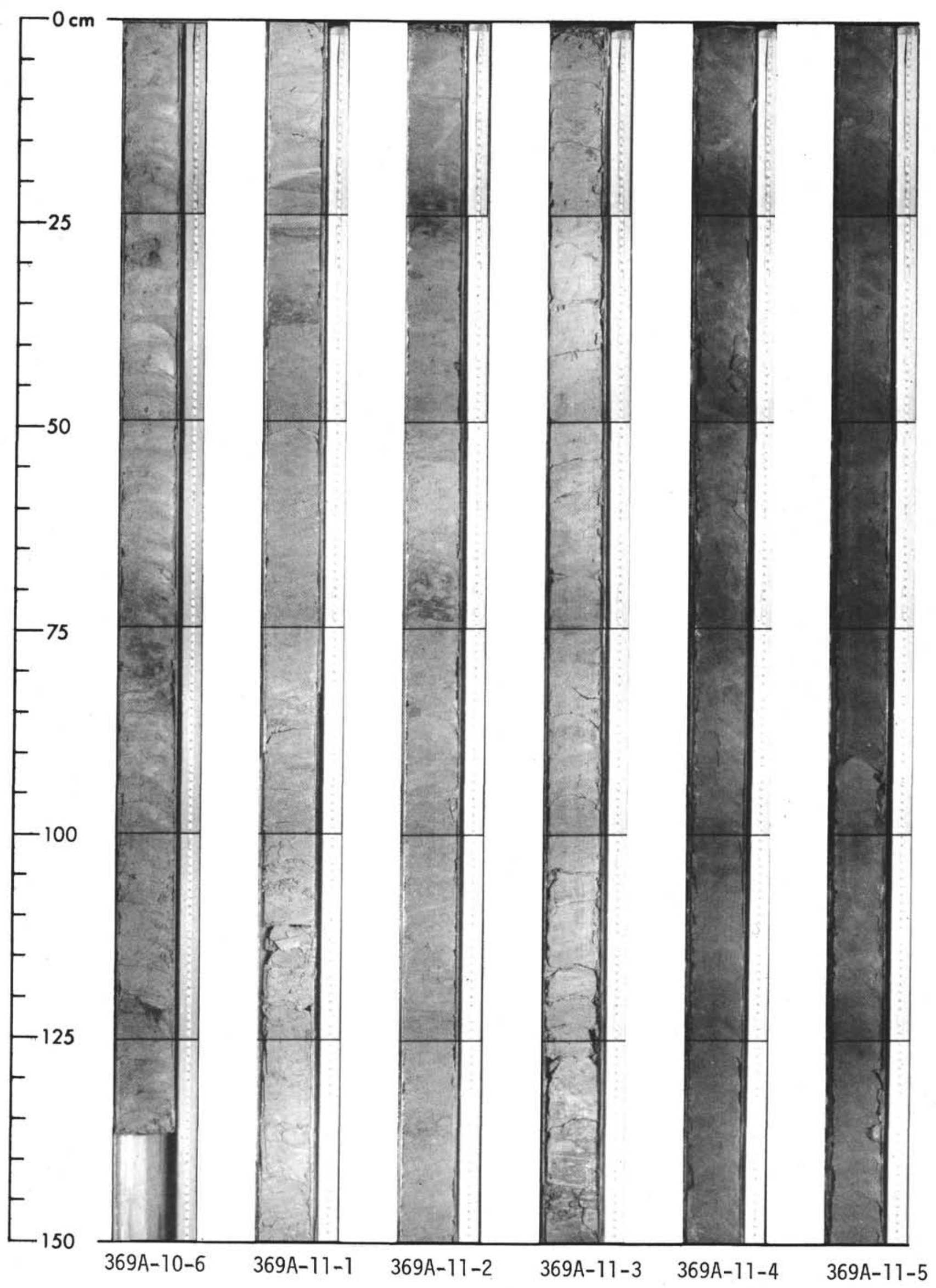




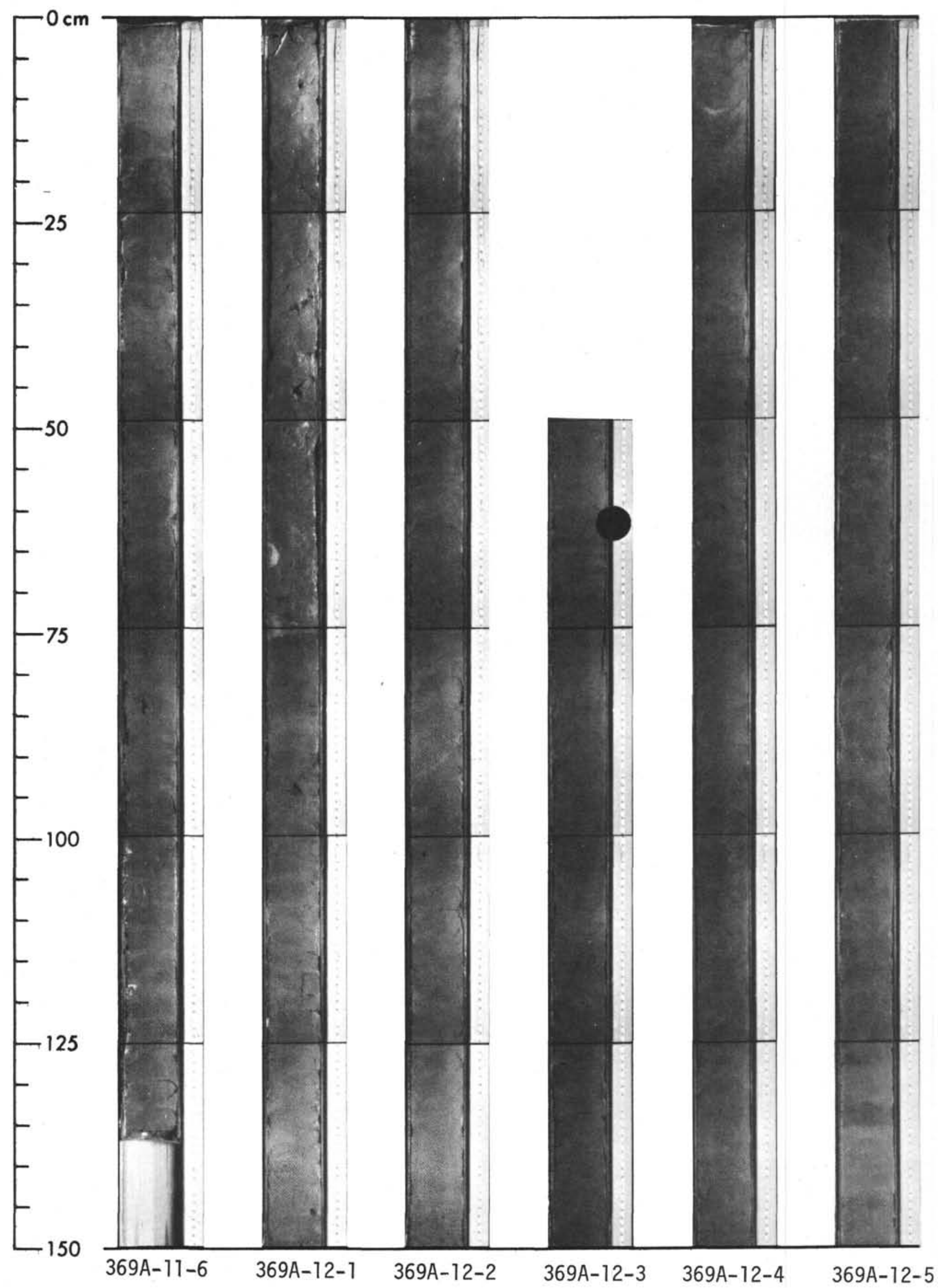




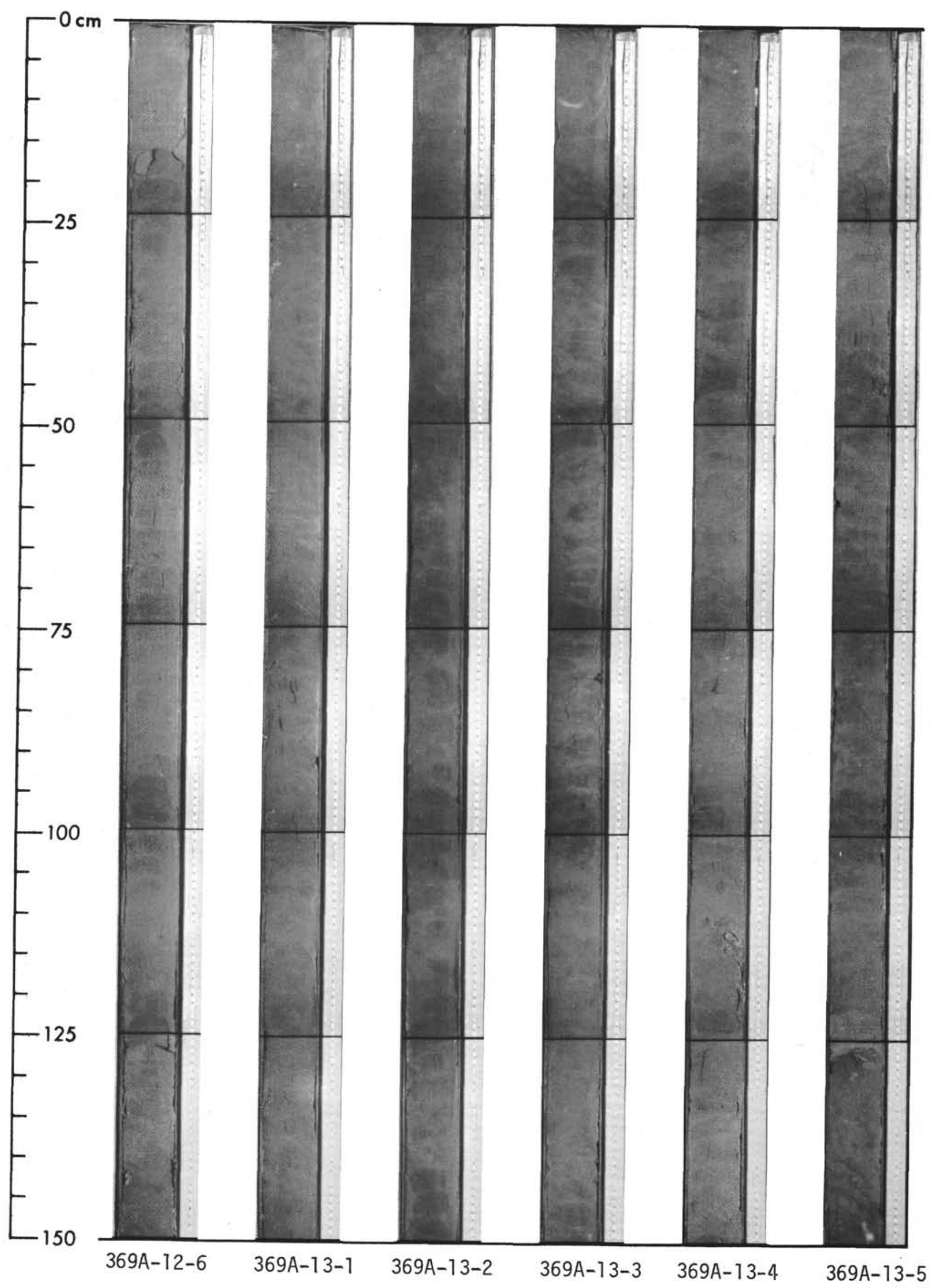




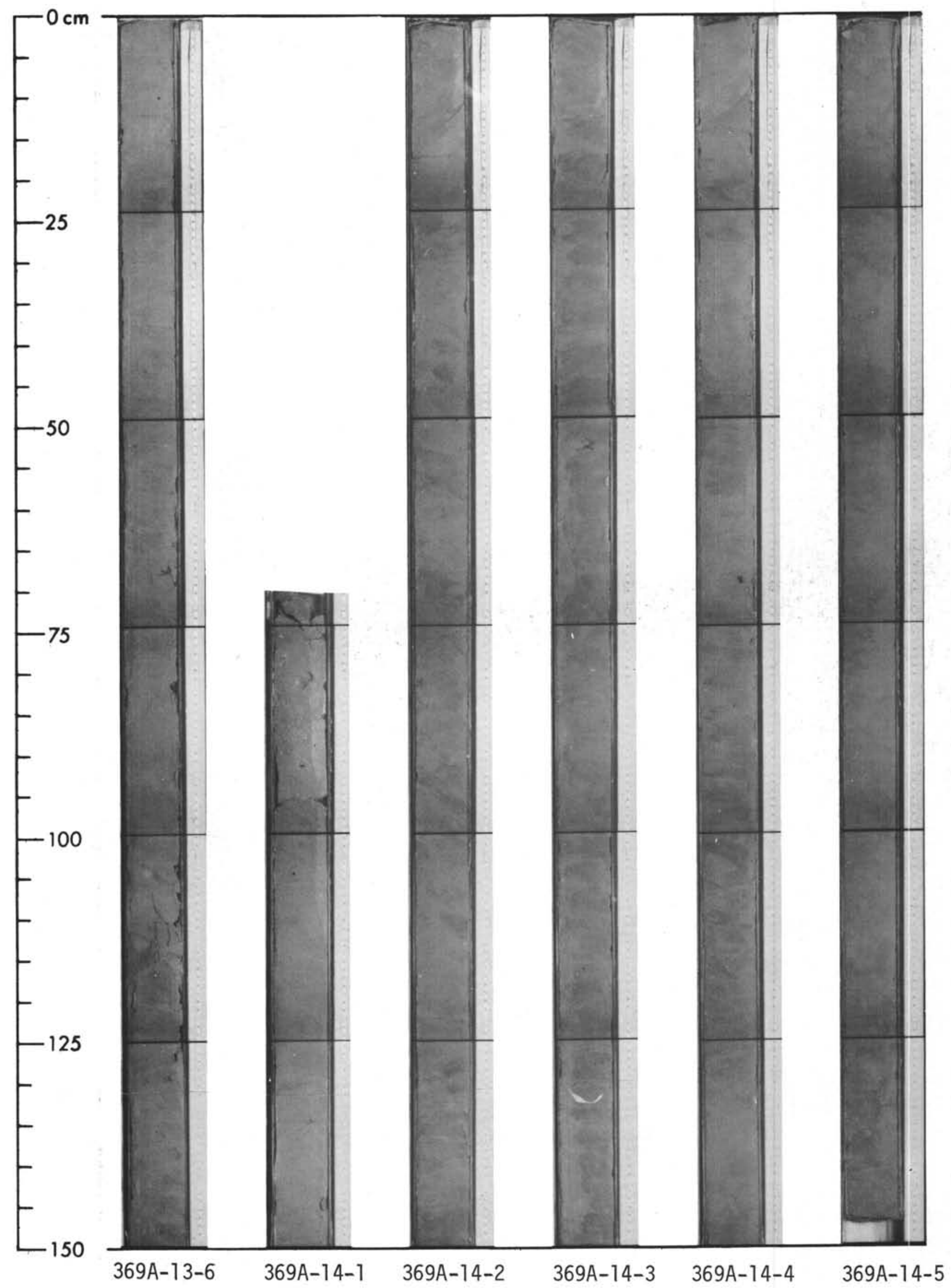




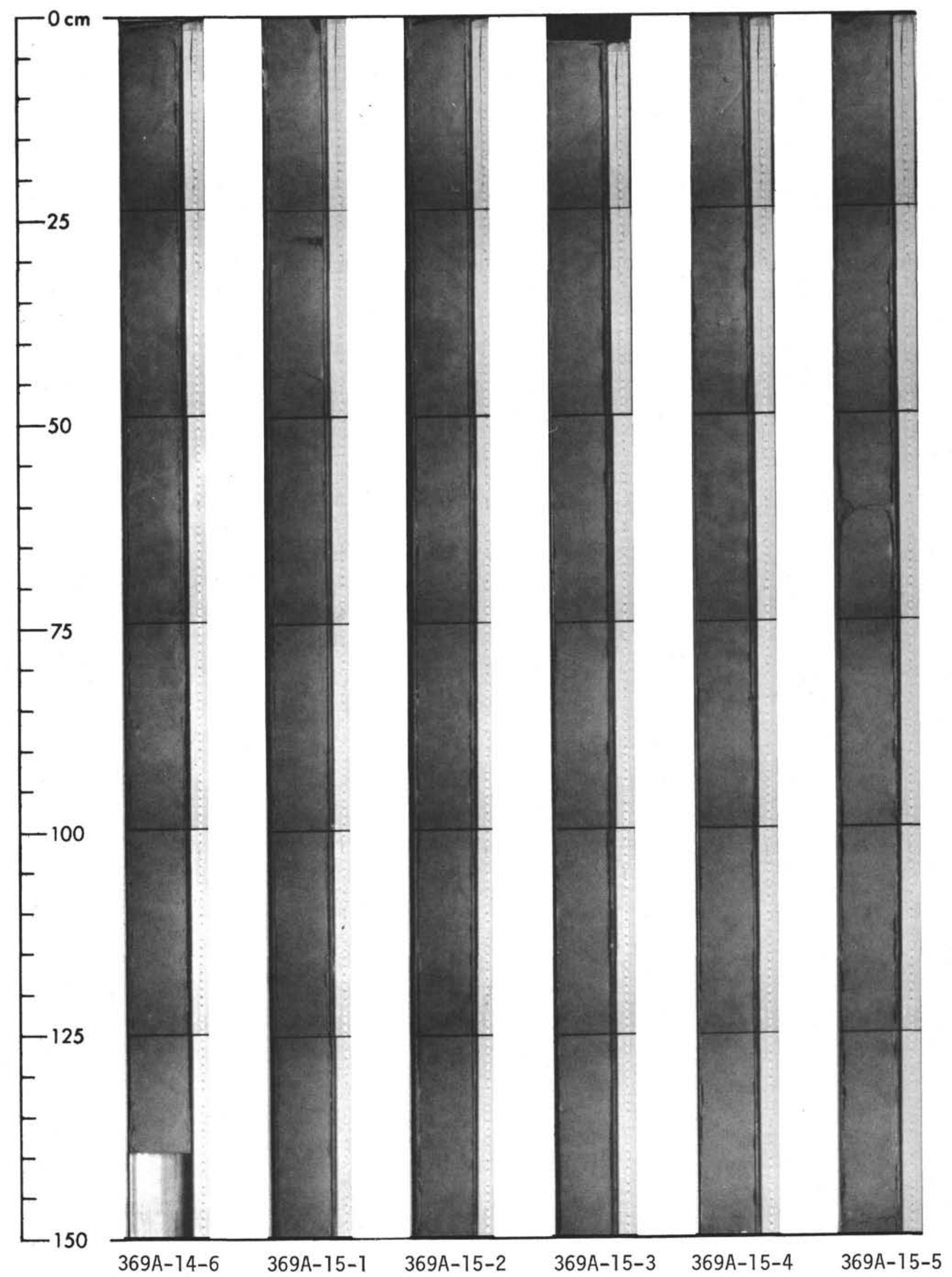




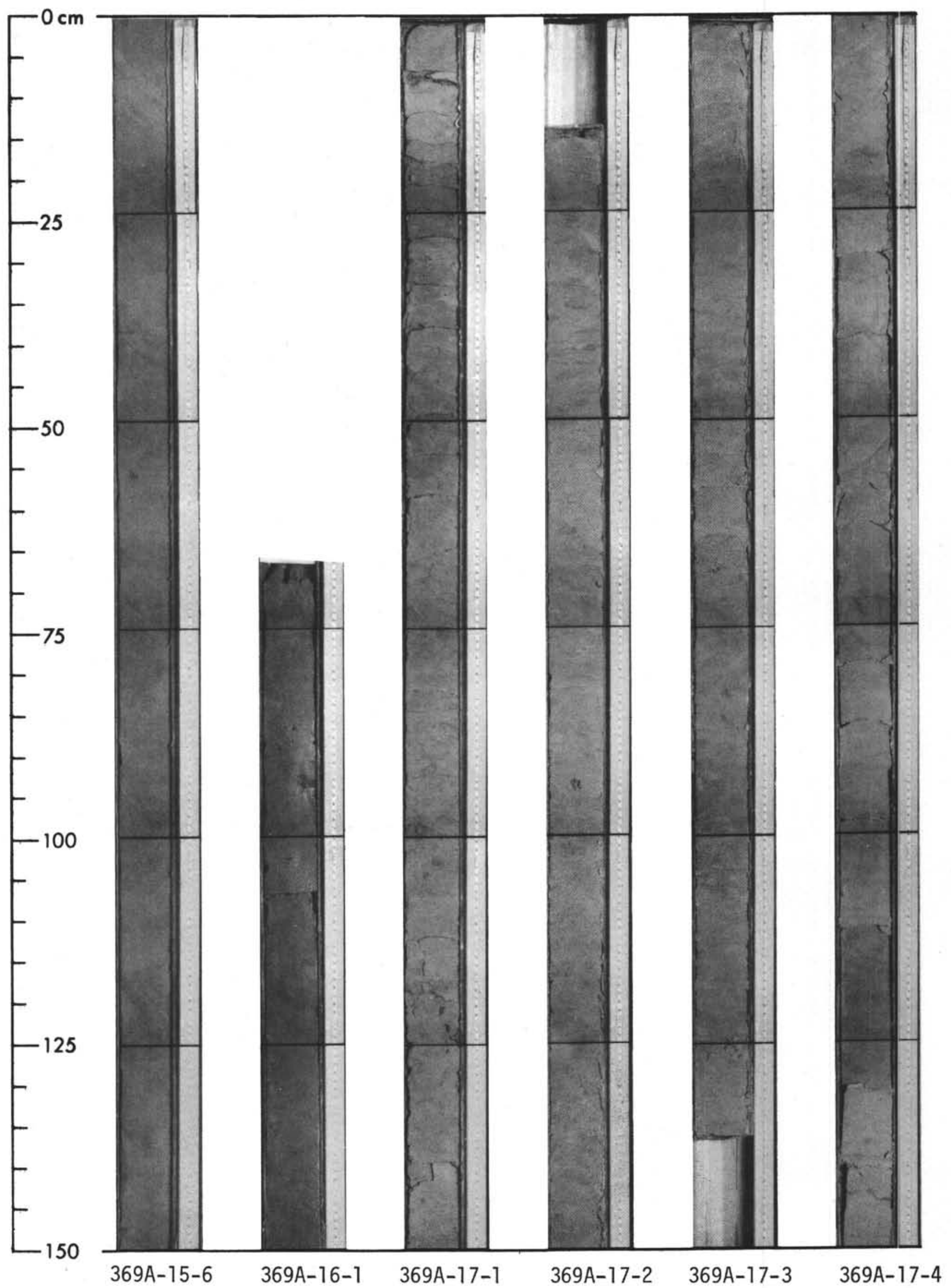




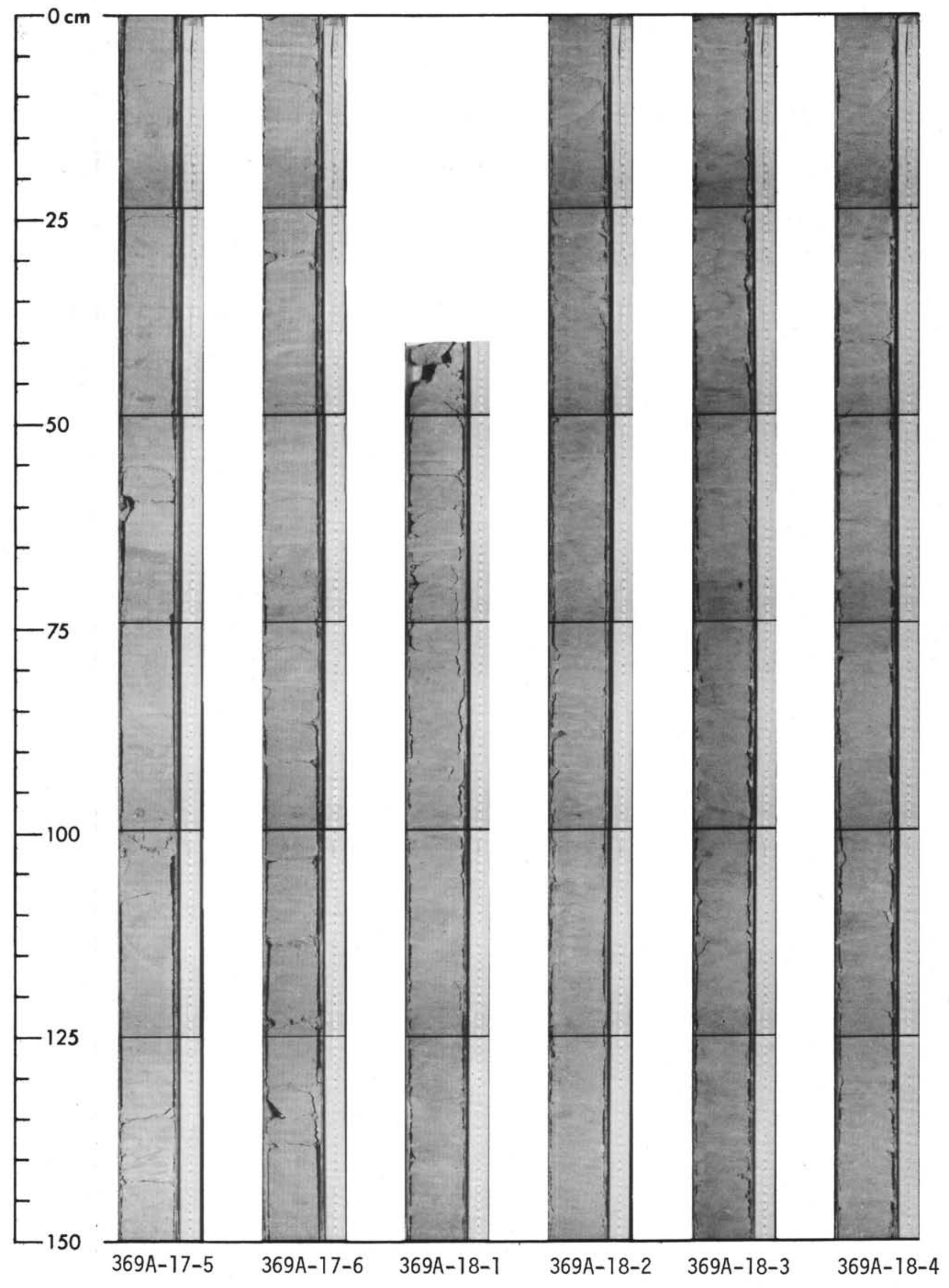


SITE 369: CONTINENTAL SLOPE OFF CAPE BOJADOR, SPANISH SAHARA

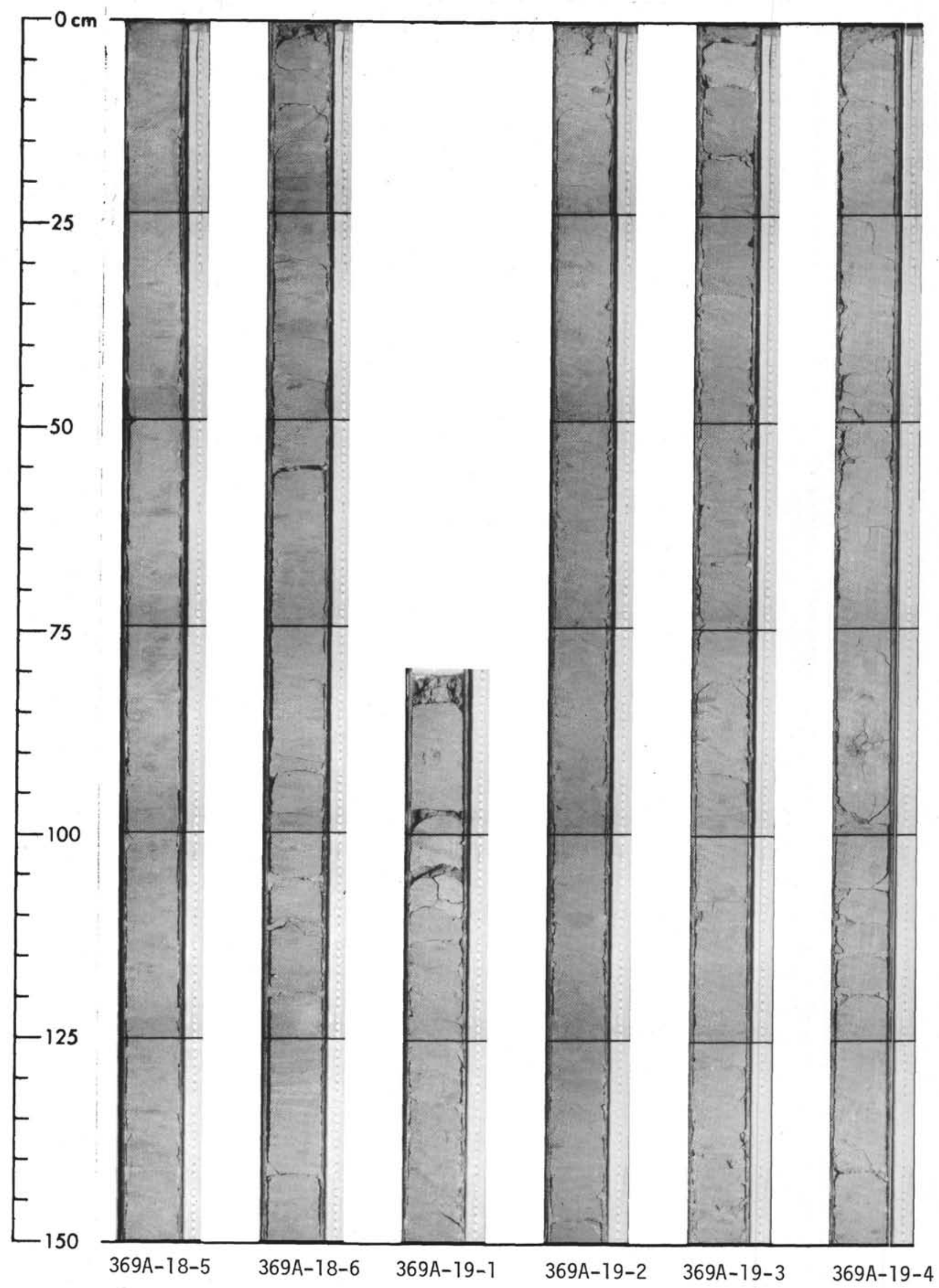




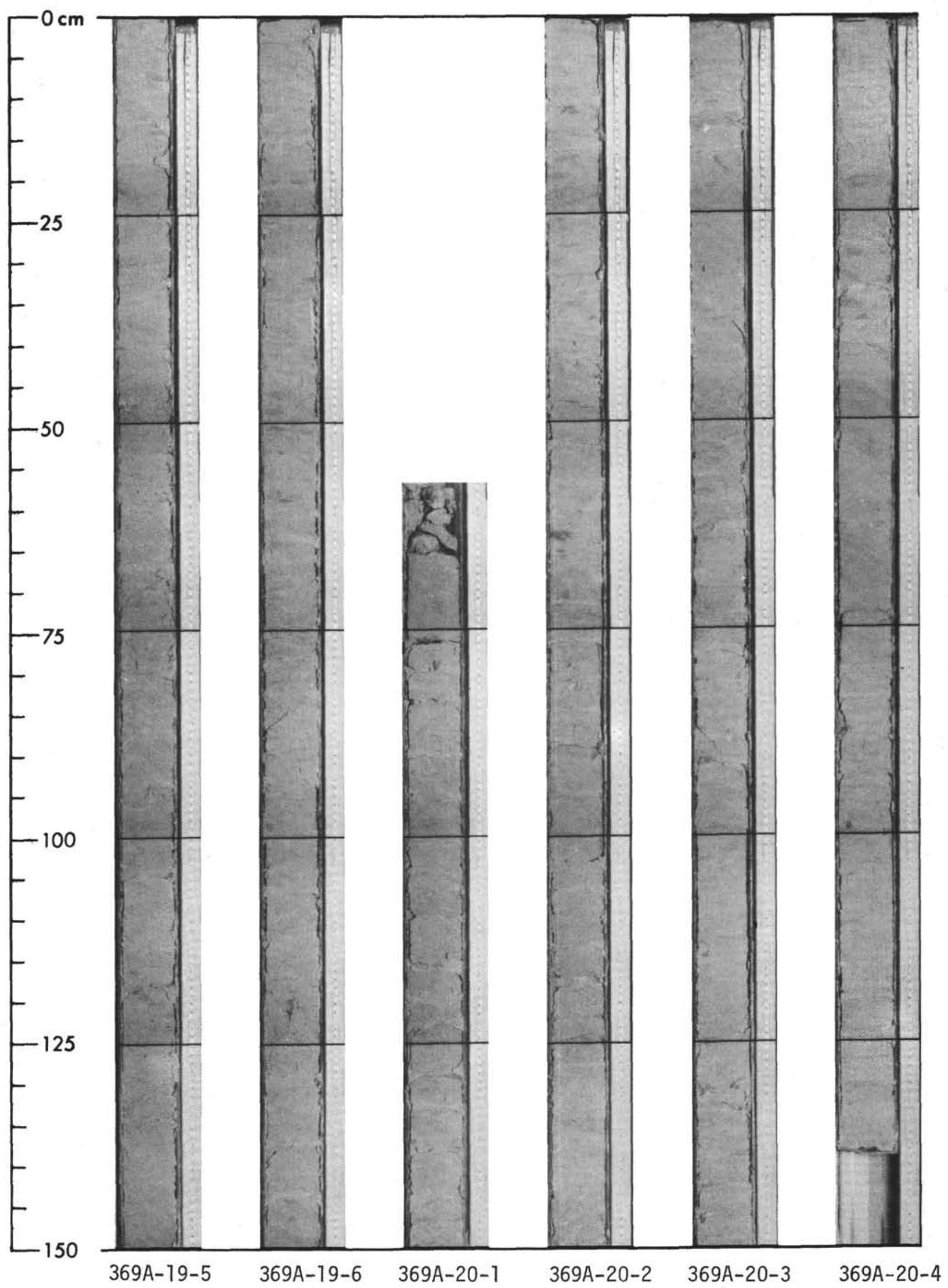


SITE 369: CONTINENTAL SLOPE OFF CAPE BOJADOR, SPANISH SAHARA

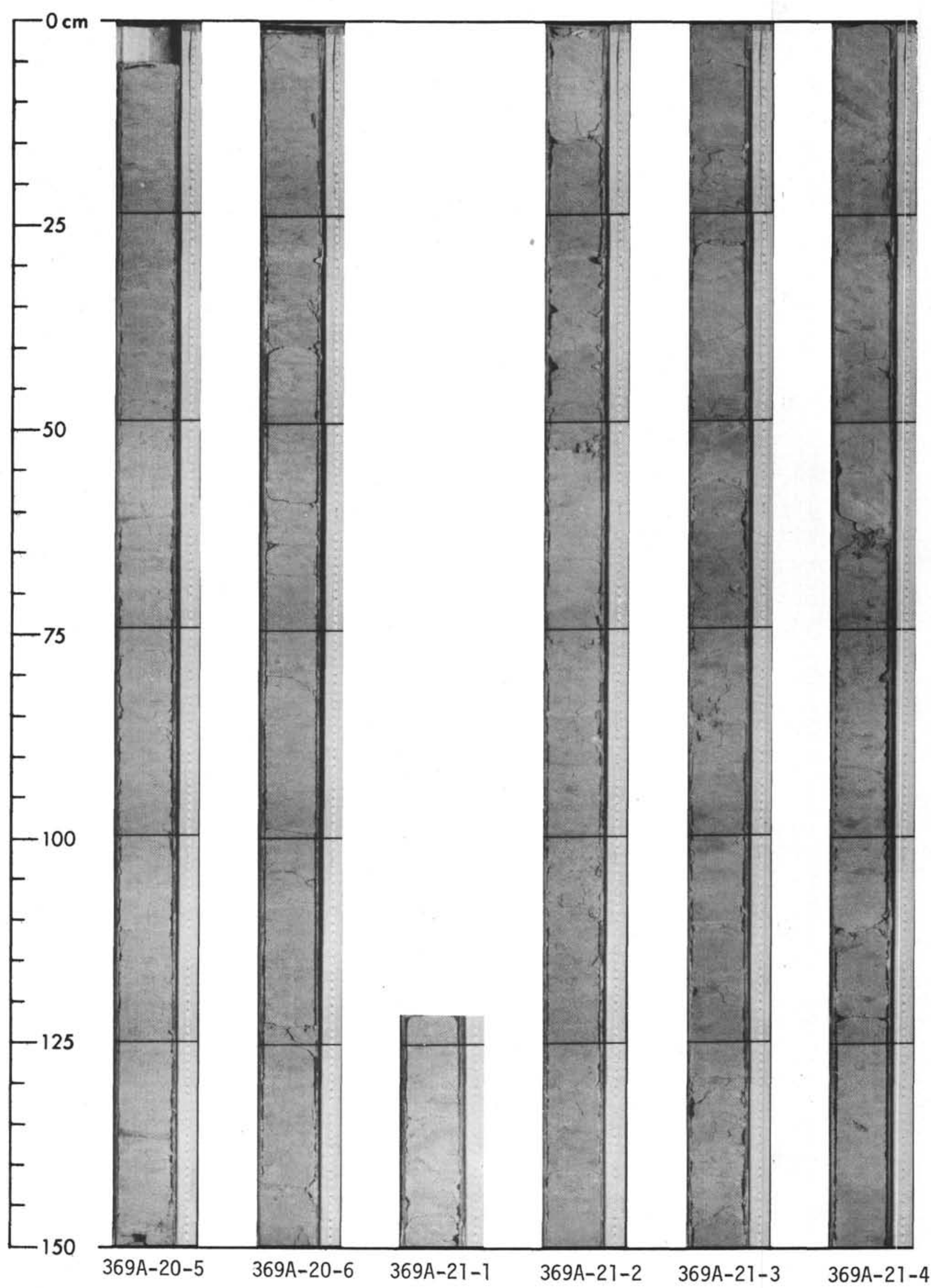


SITE 369: CONTINENTAL SLOPE OFF CAPE BOJADOR, SPANISH SAHARA

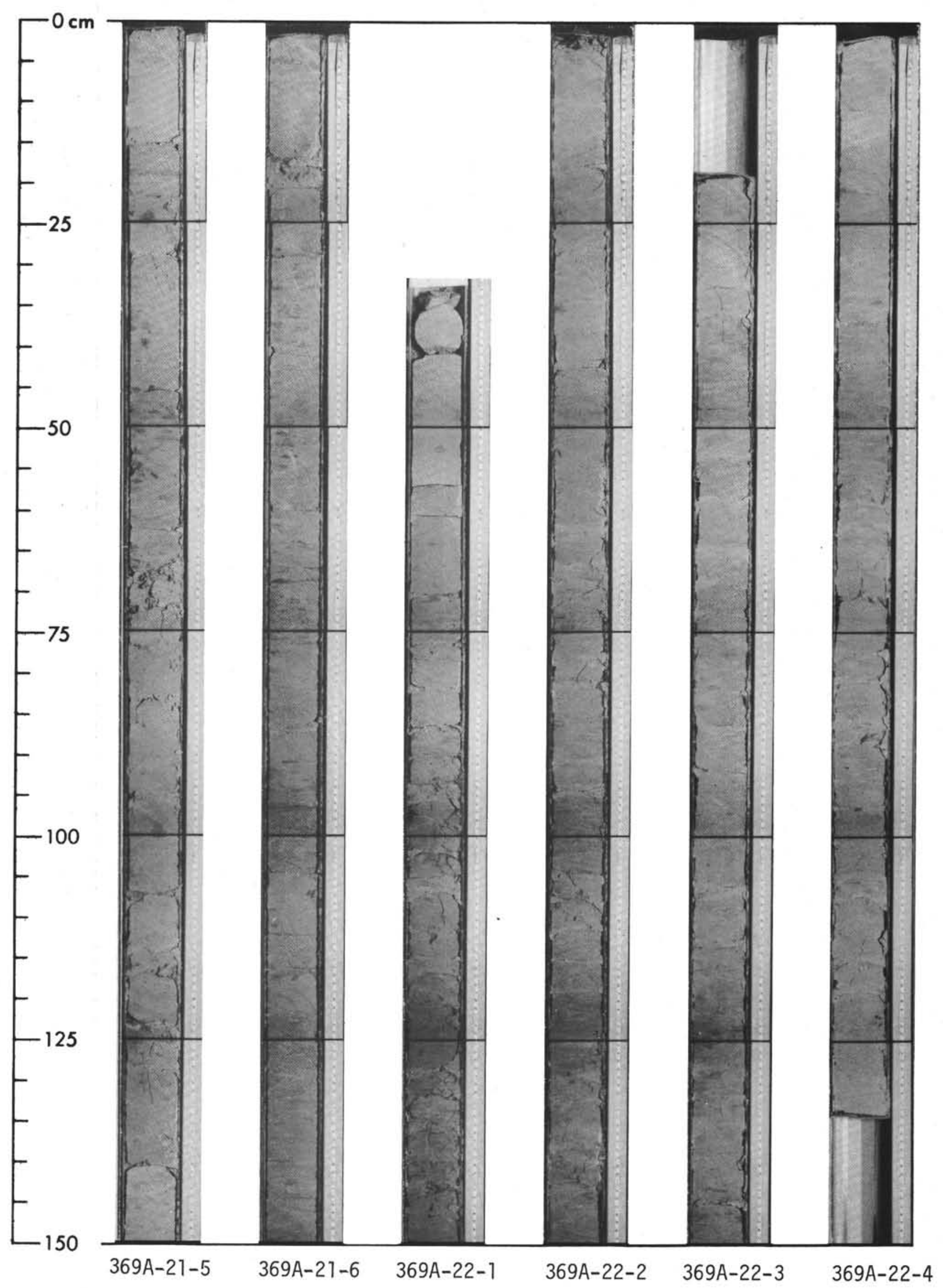




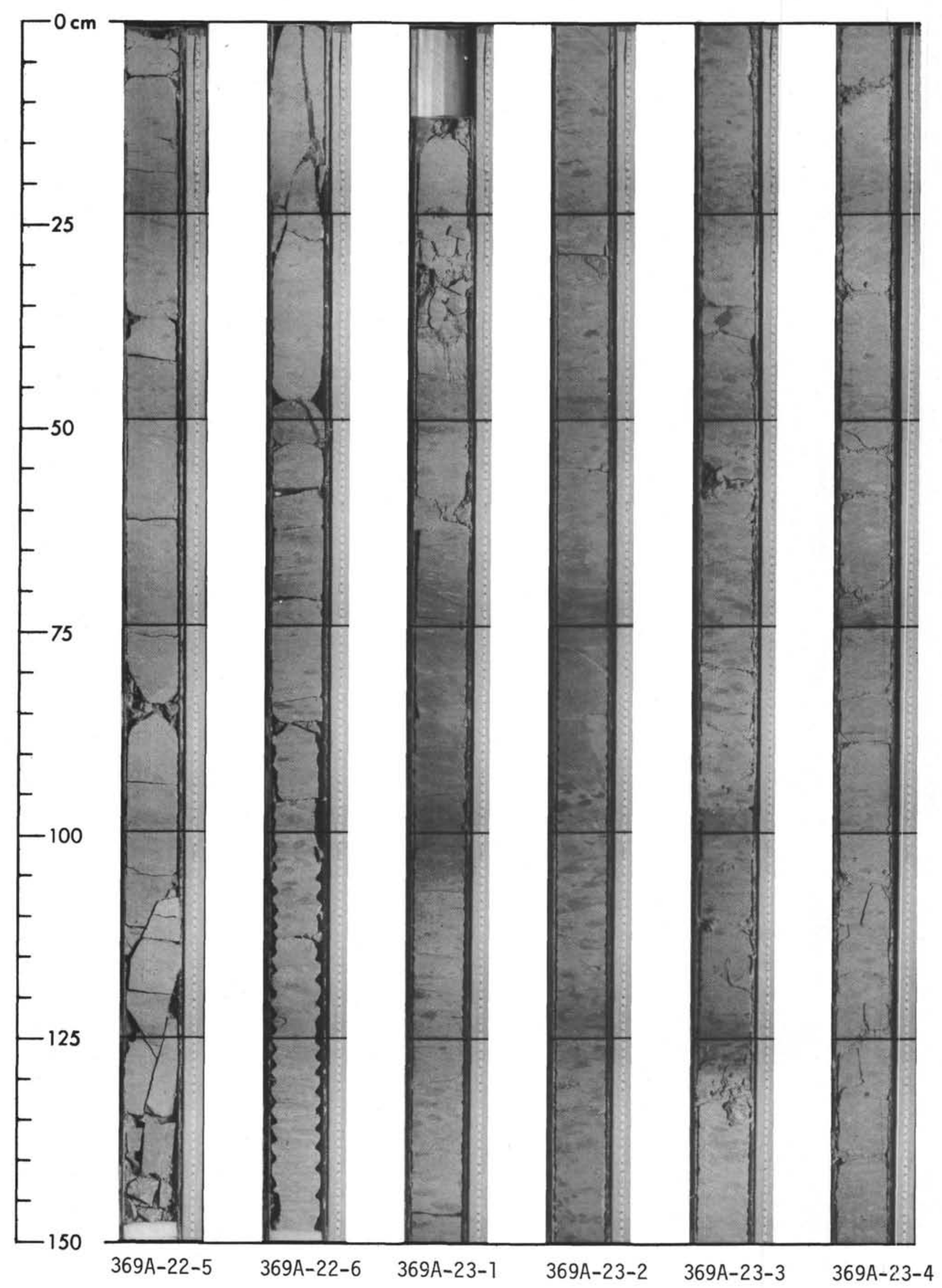




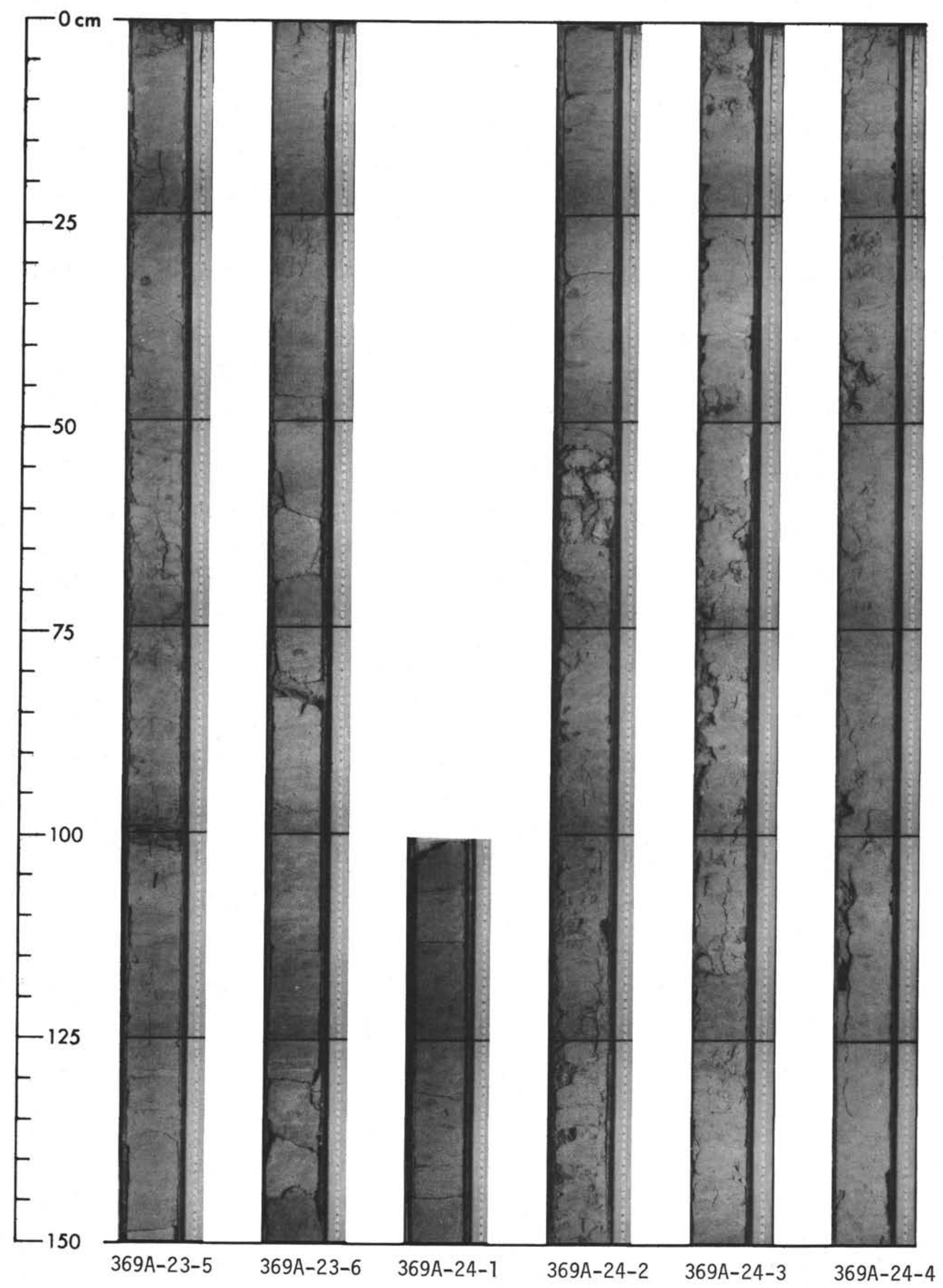


SITE 369: CONTINENTAL SLOPE OFF CAPE BOJADOR, SPANISH SAHARA

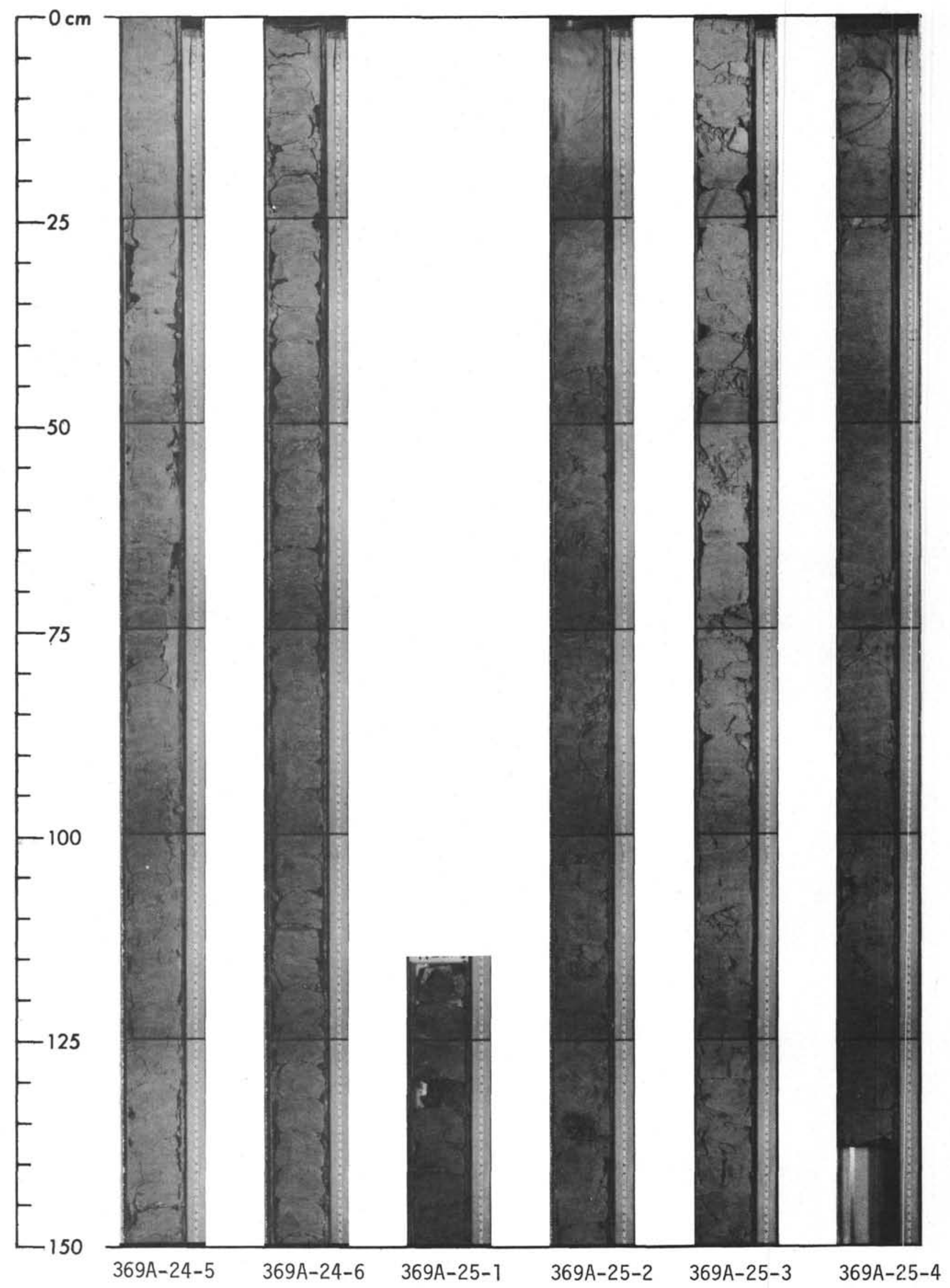




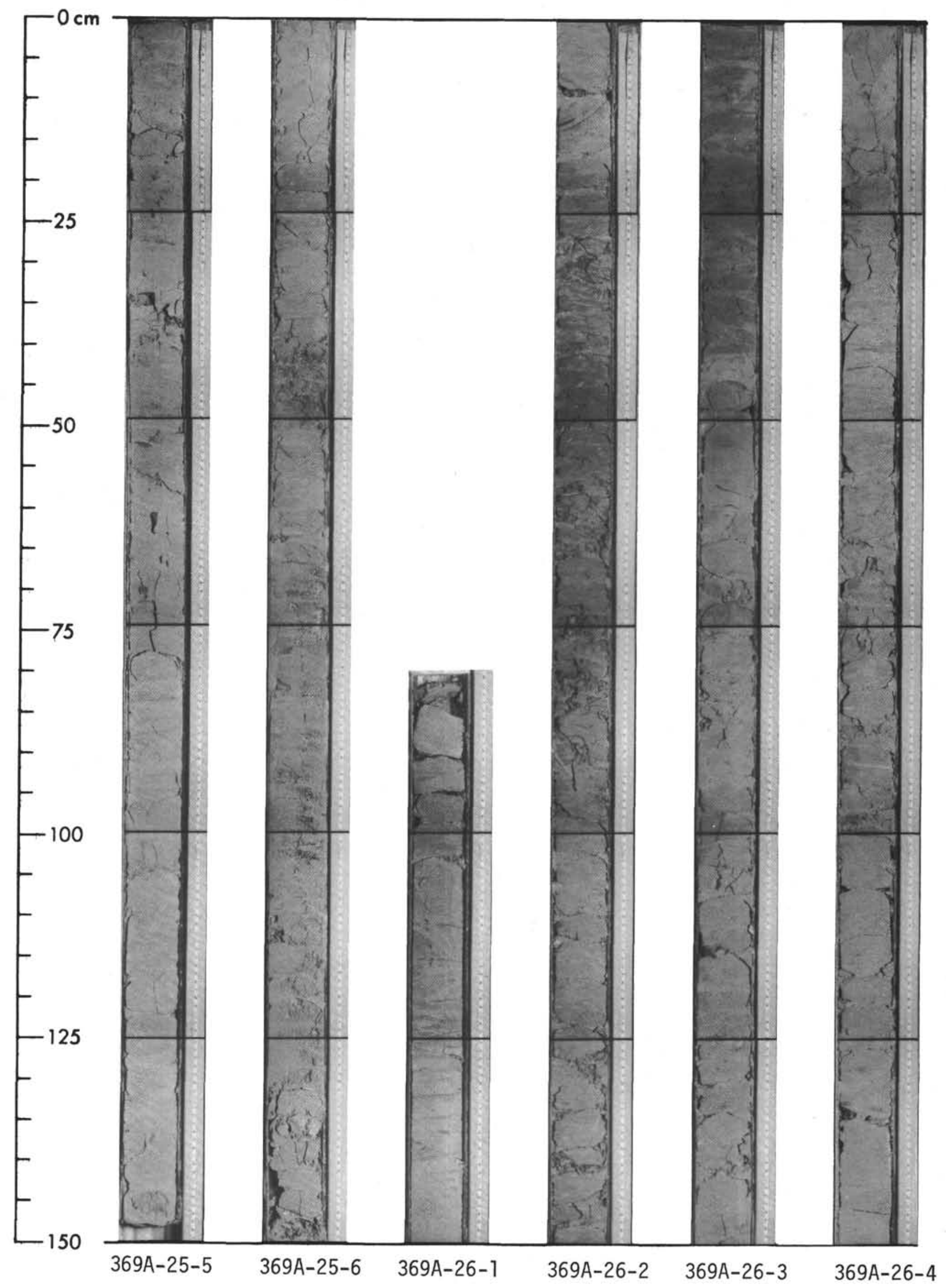


SITE 369: CONTINENTAL SLOPE OFF CAPE BOJADOR, SPANISH SAHARA

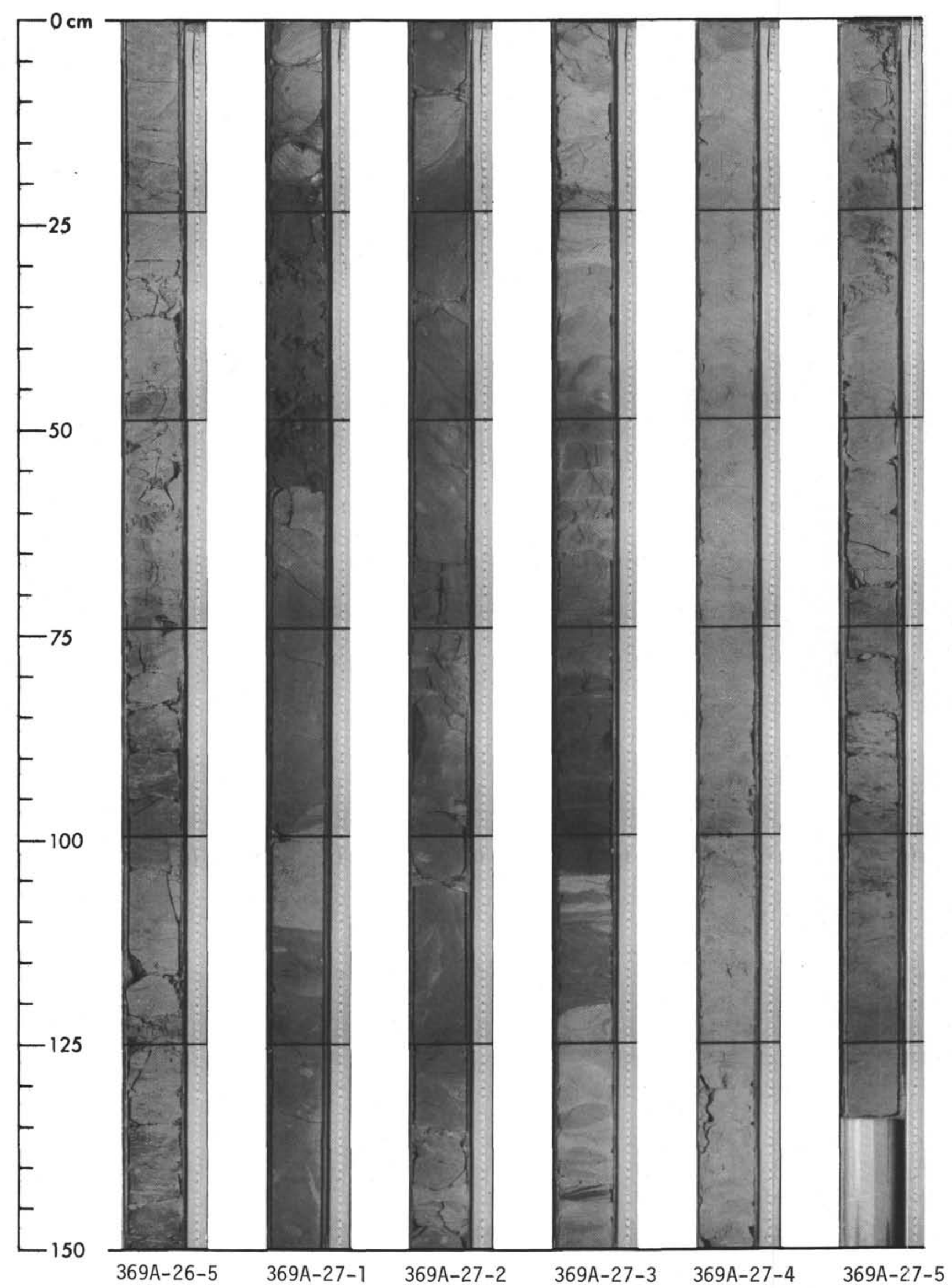




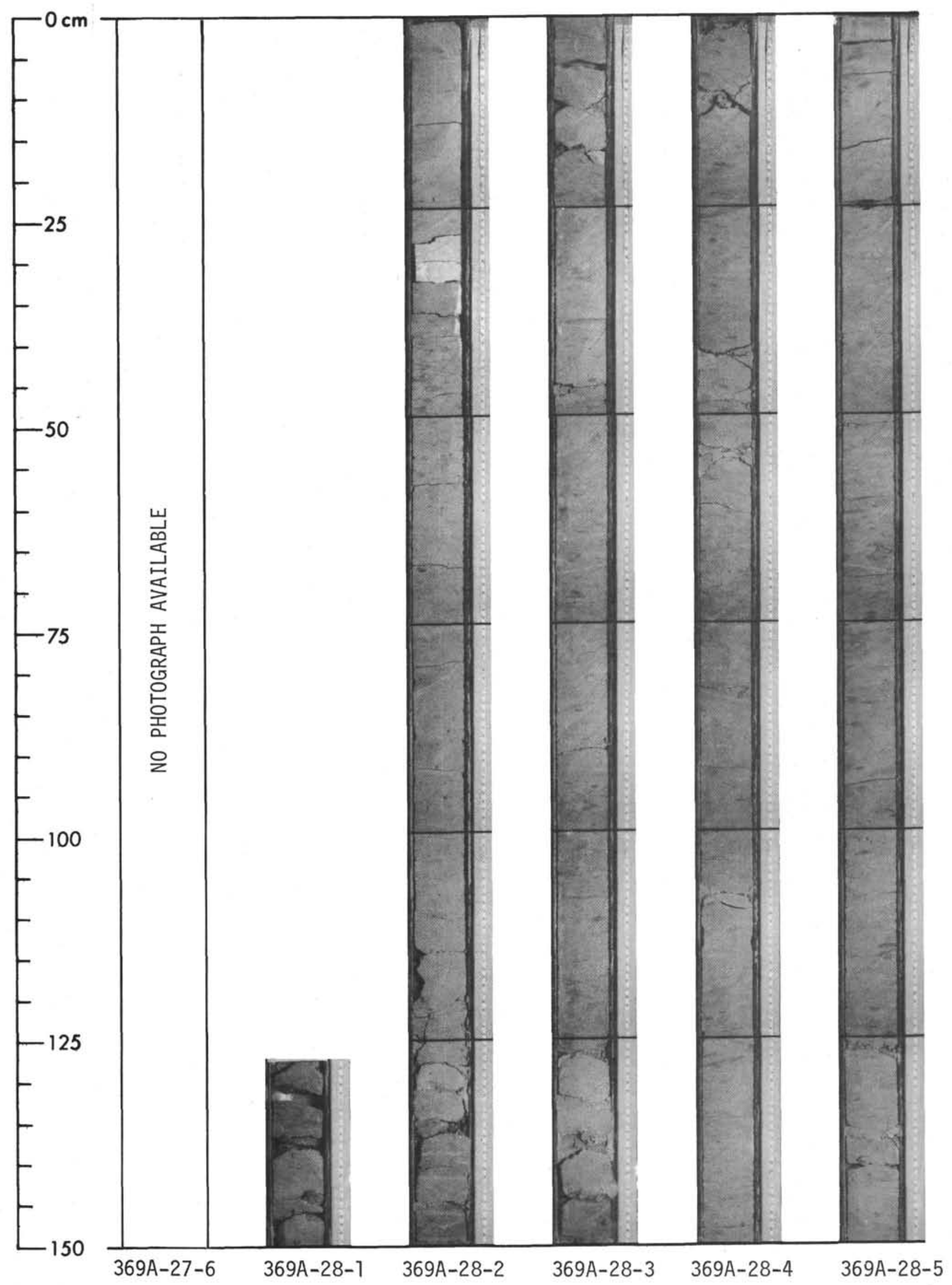




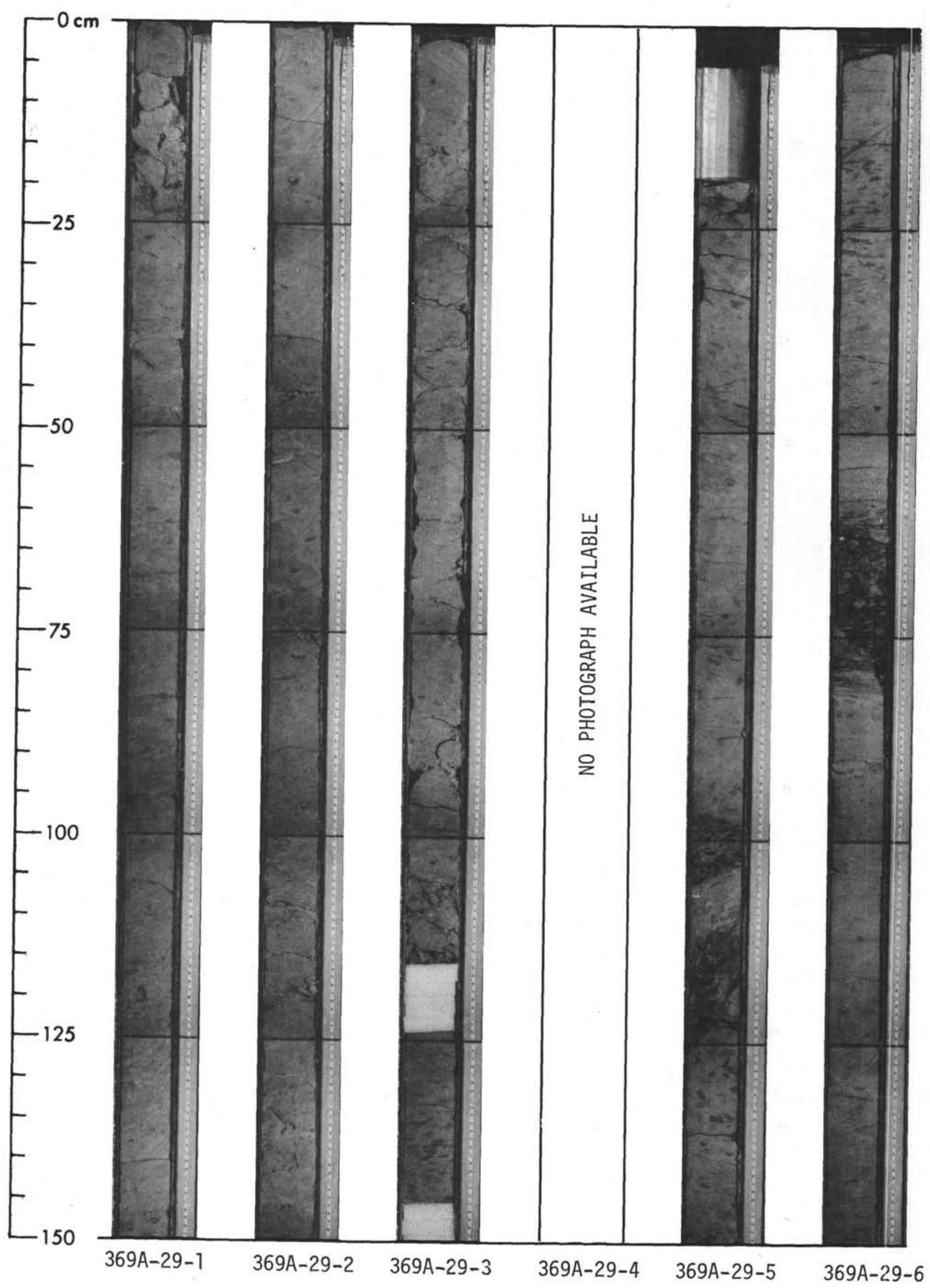




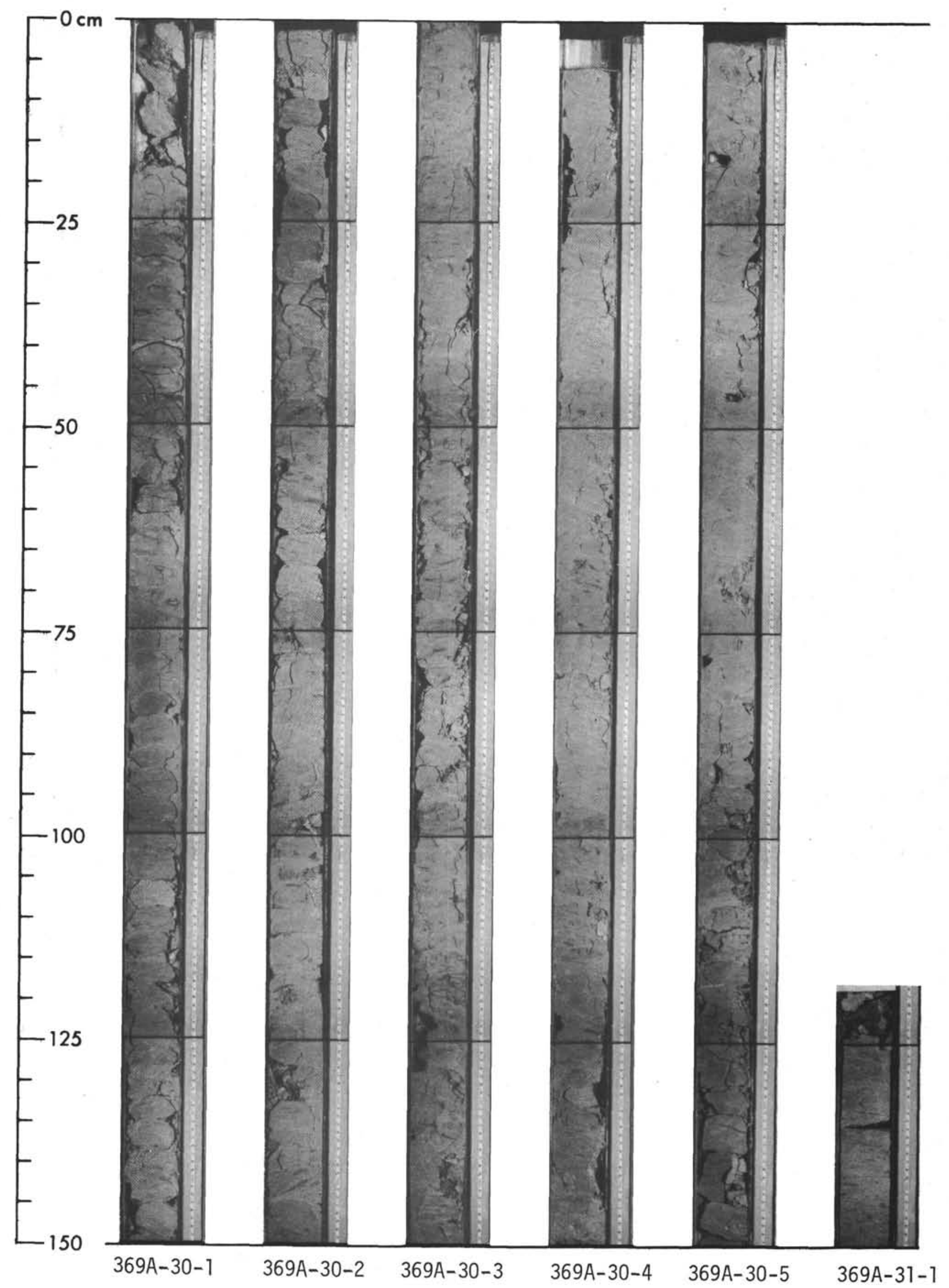




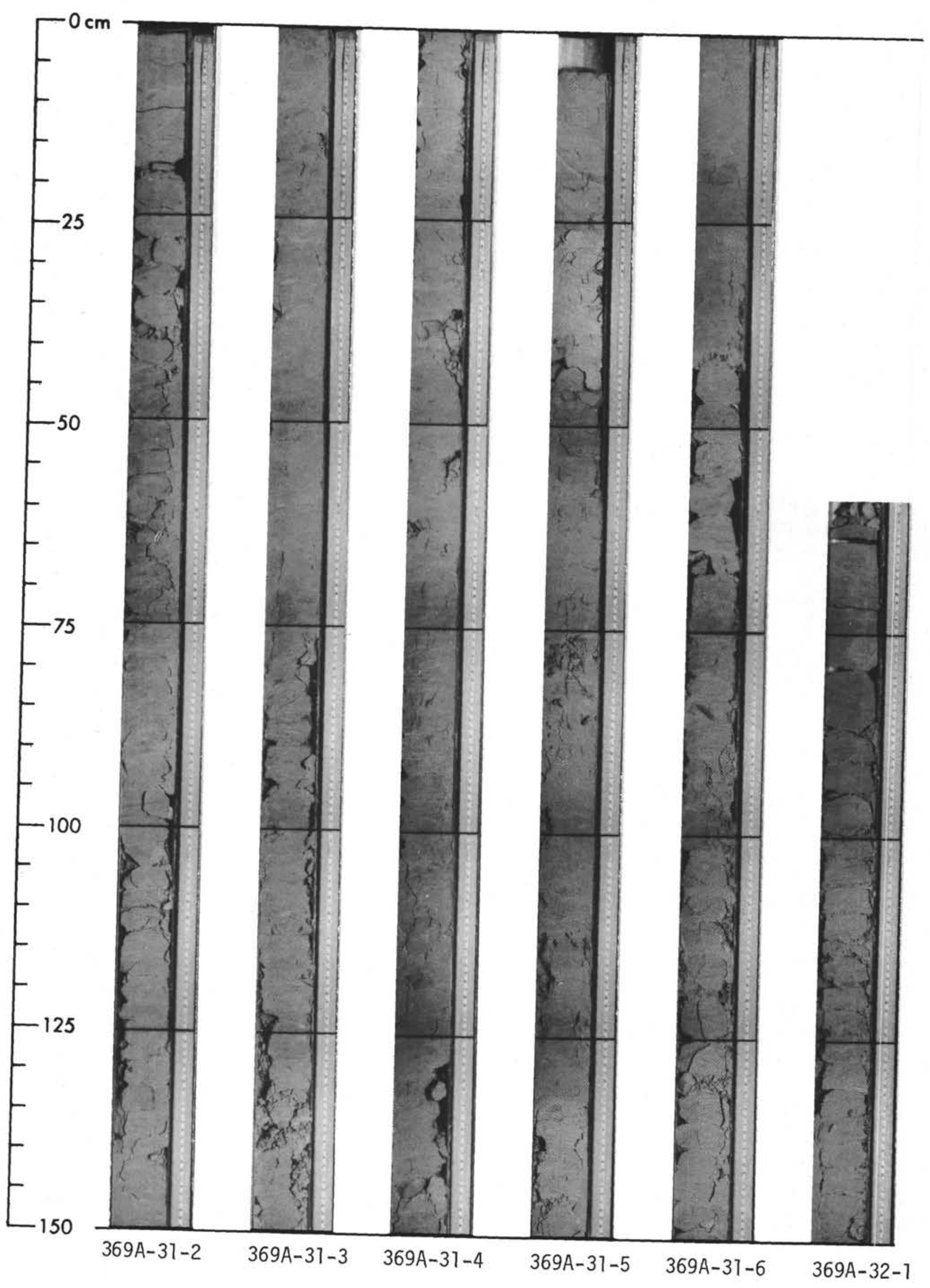




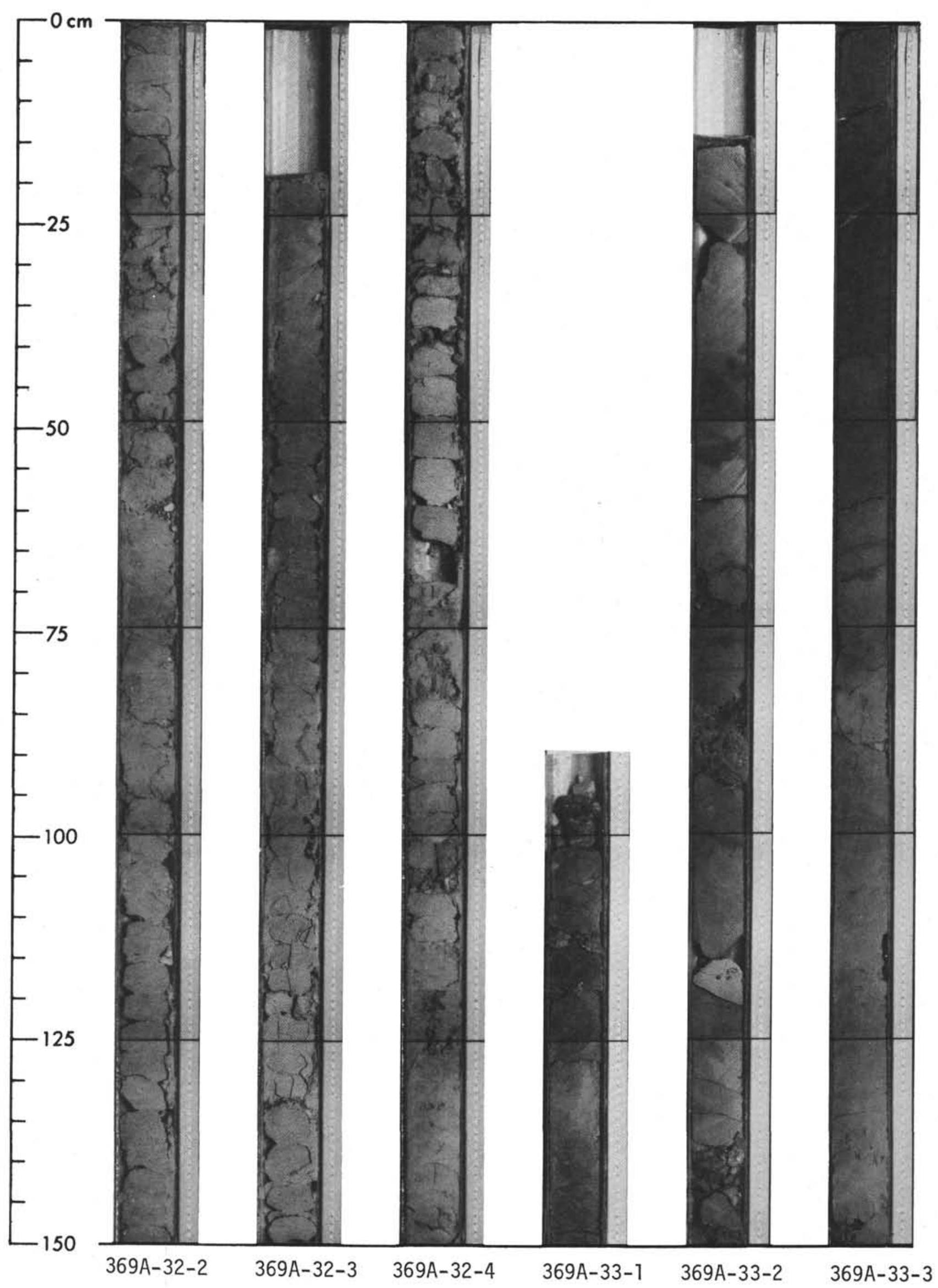




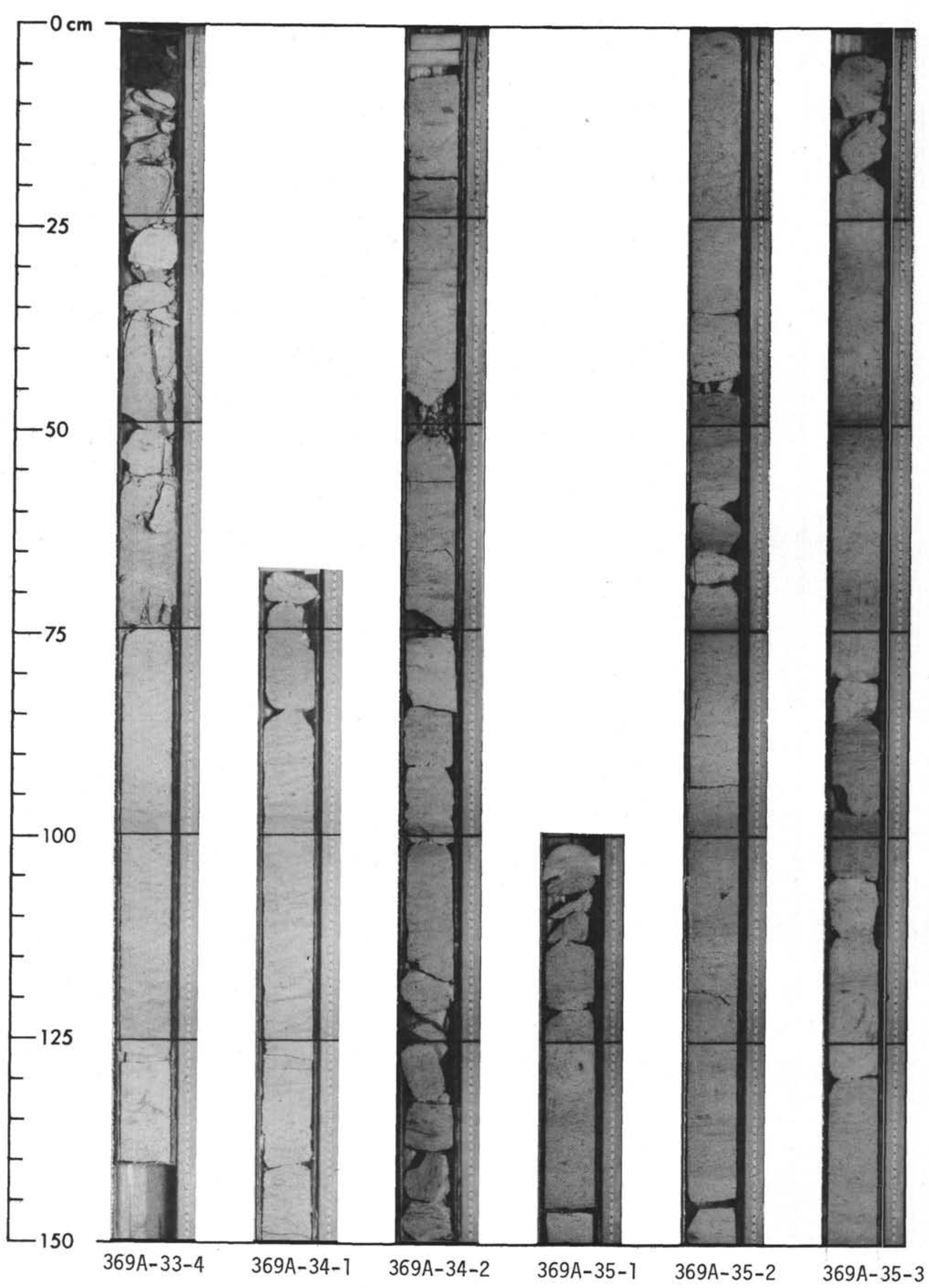




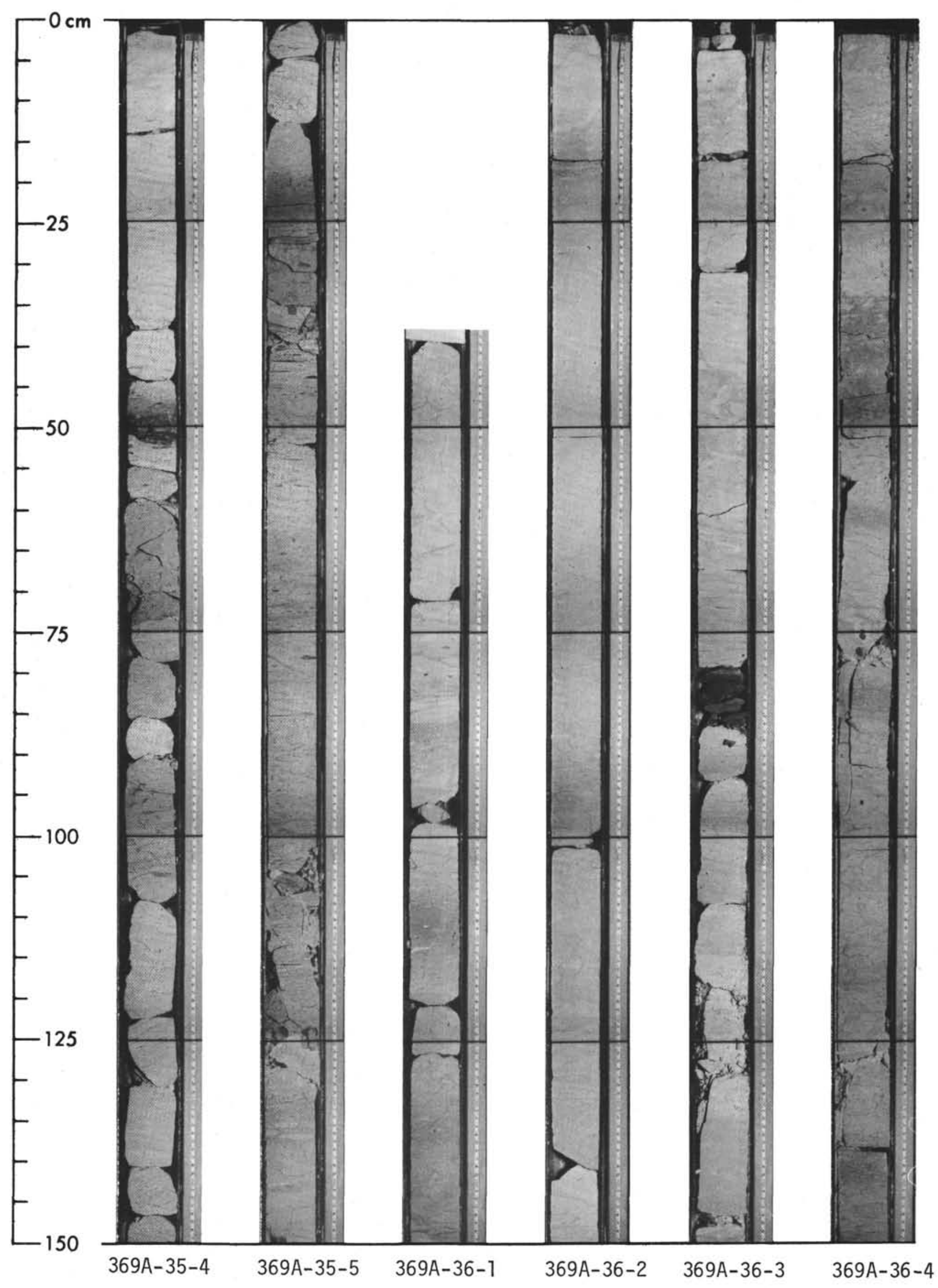


SITE 369: CONTINENTAL SLOPE OFF CAPE BOJADOR, SPANISH SAHARA

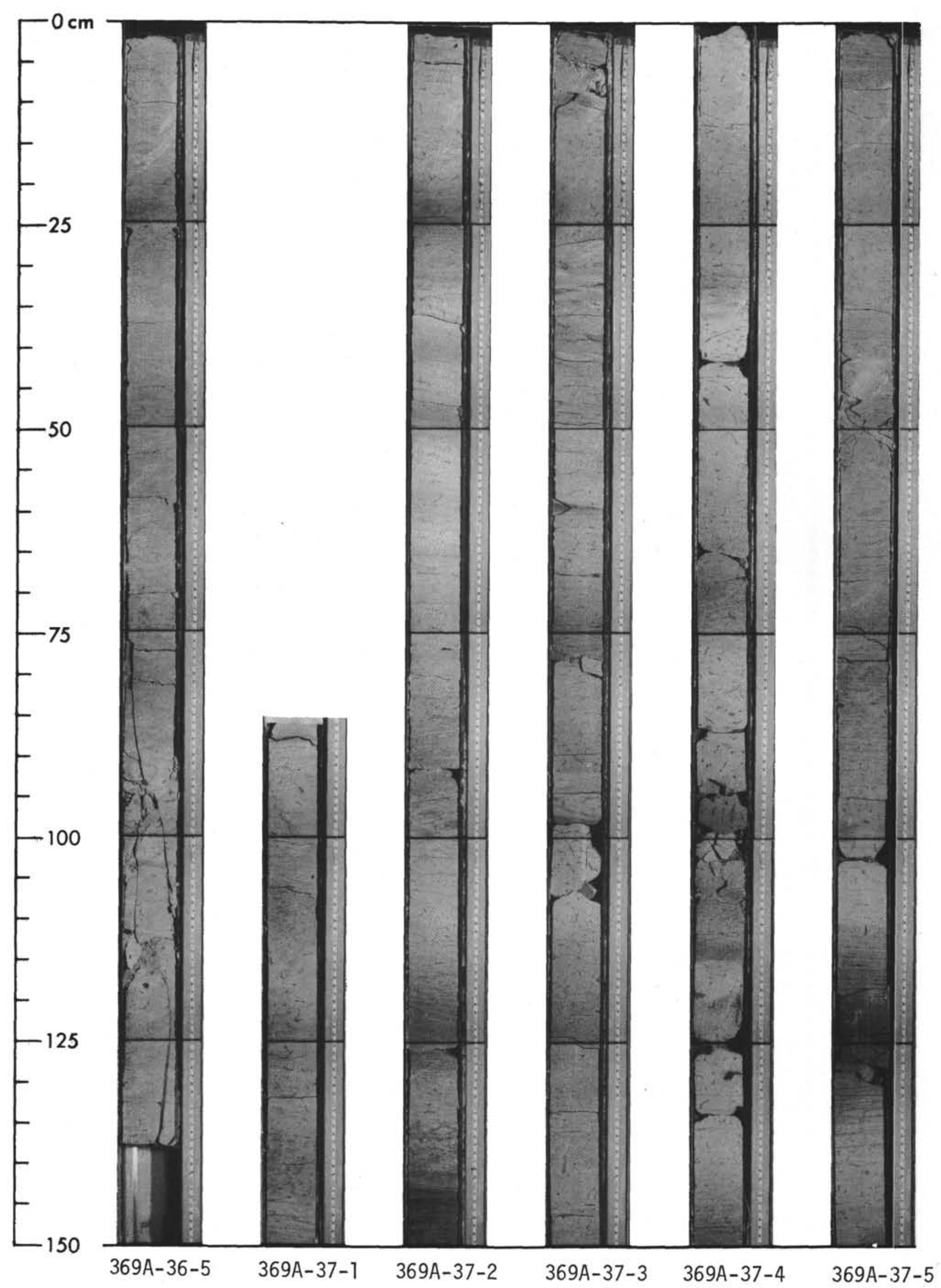




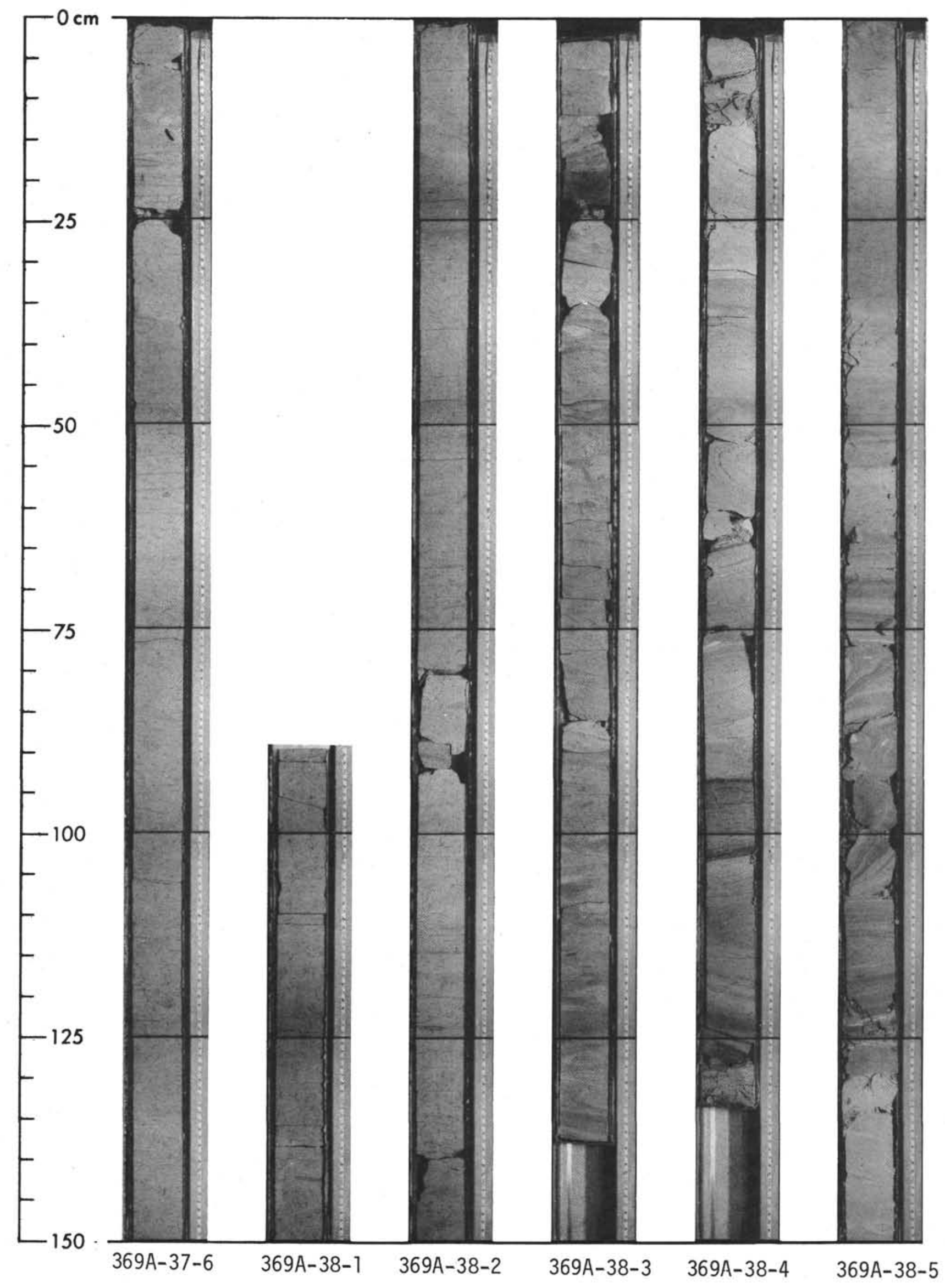




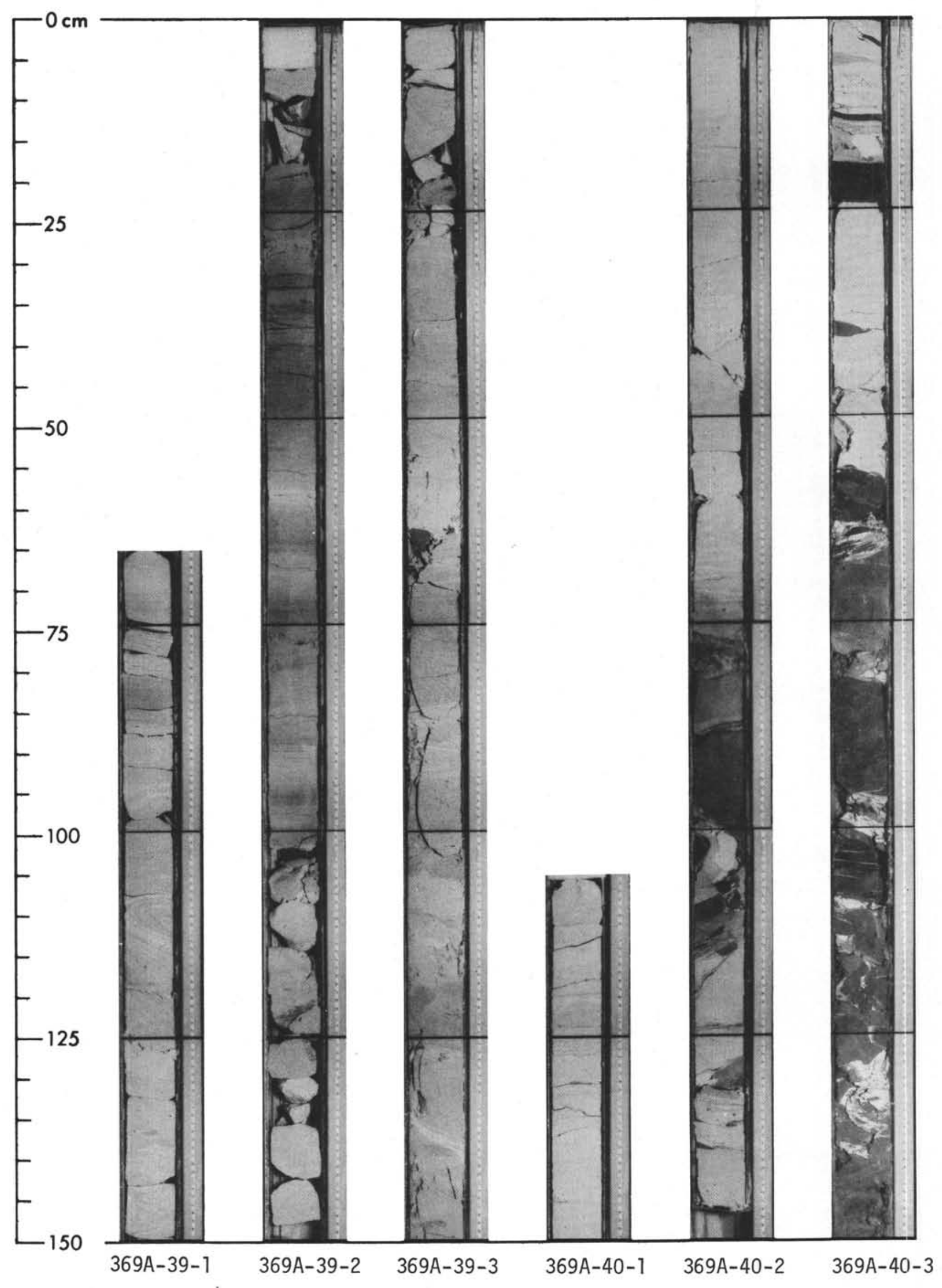


SITE 369: CONTINENTAL SLOPE OFF CAPE BOJADOR, SPANISH SAHARA

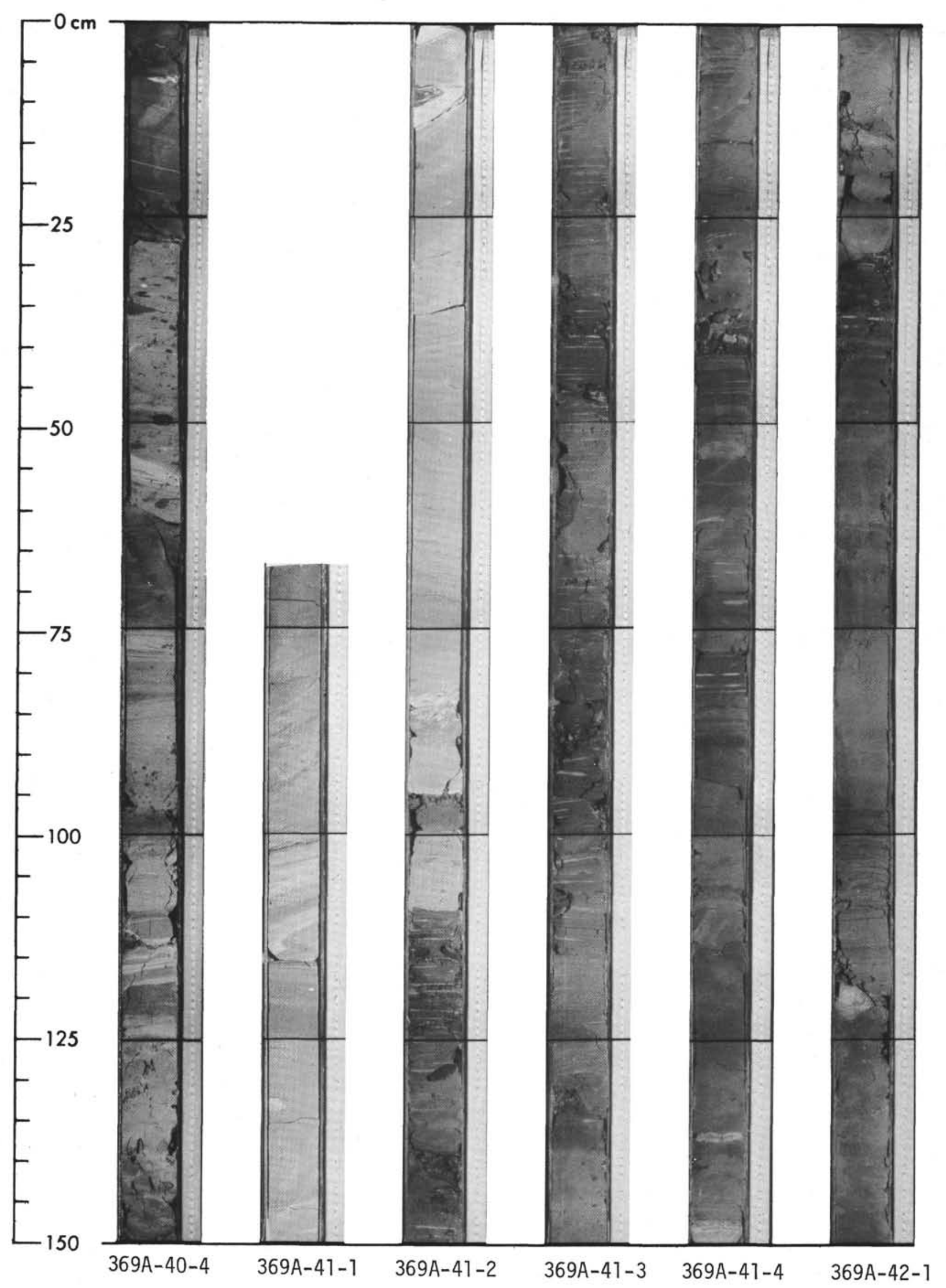




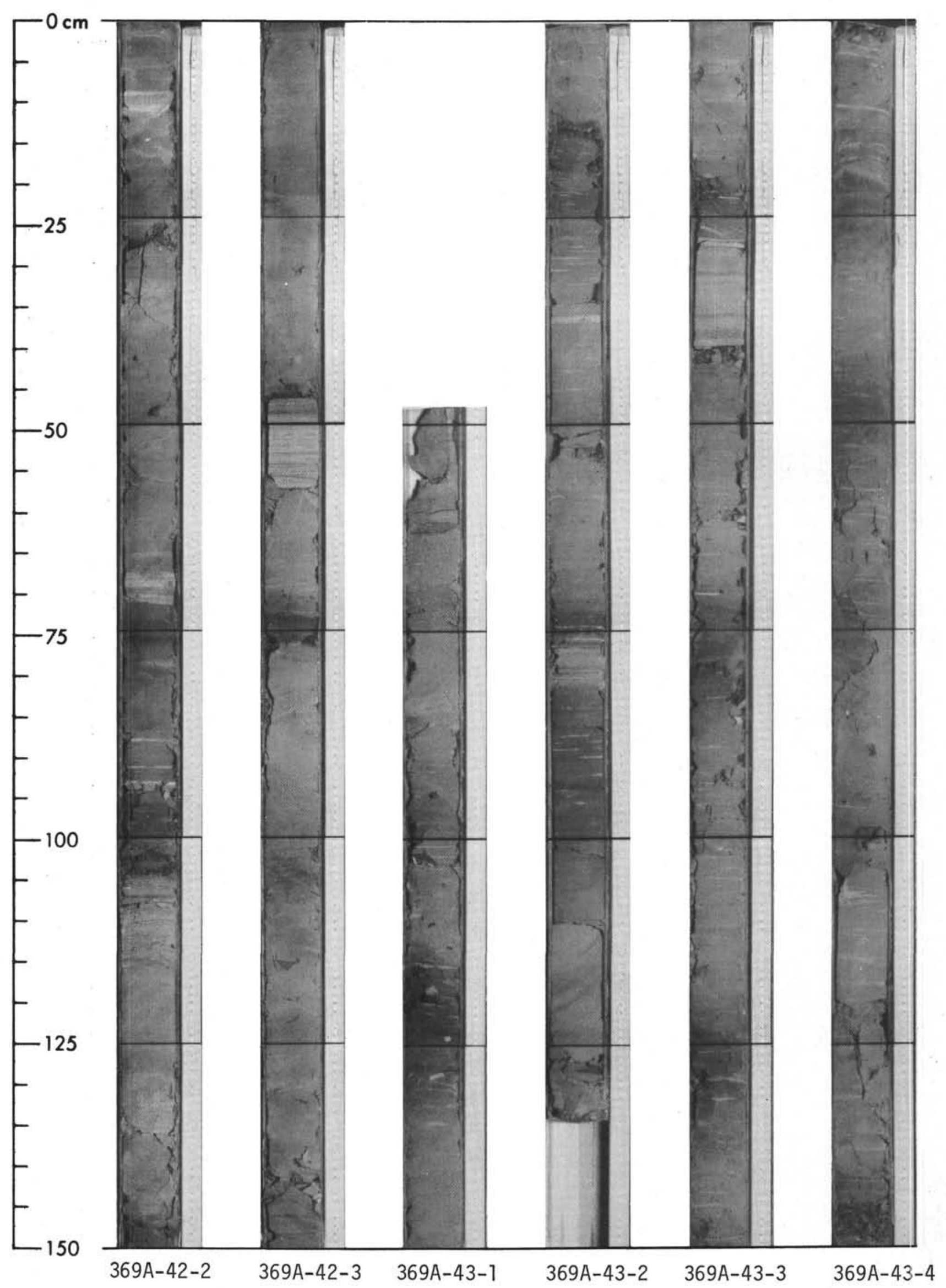




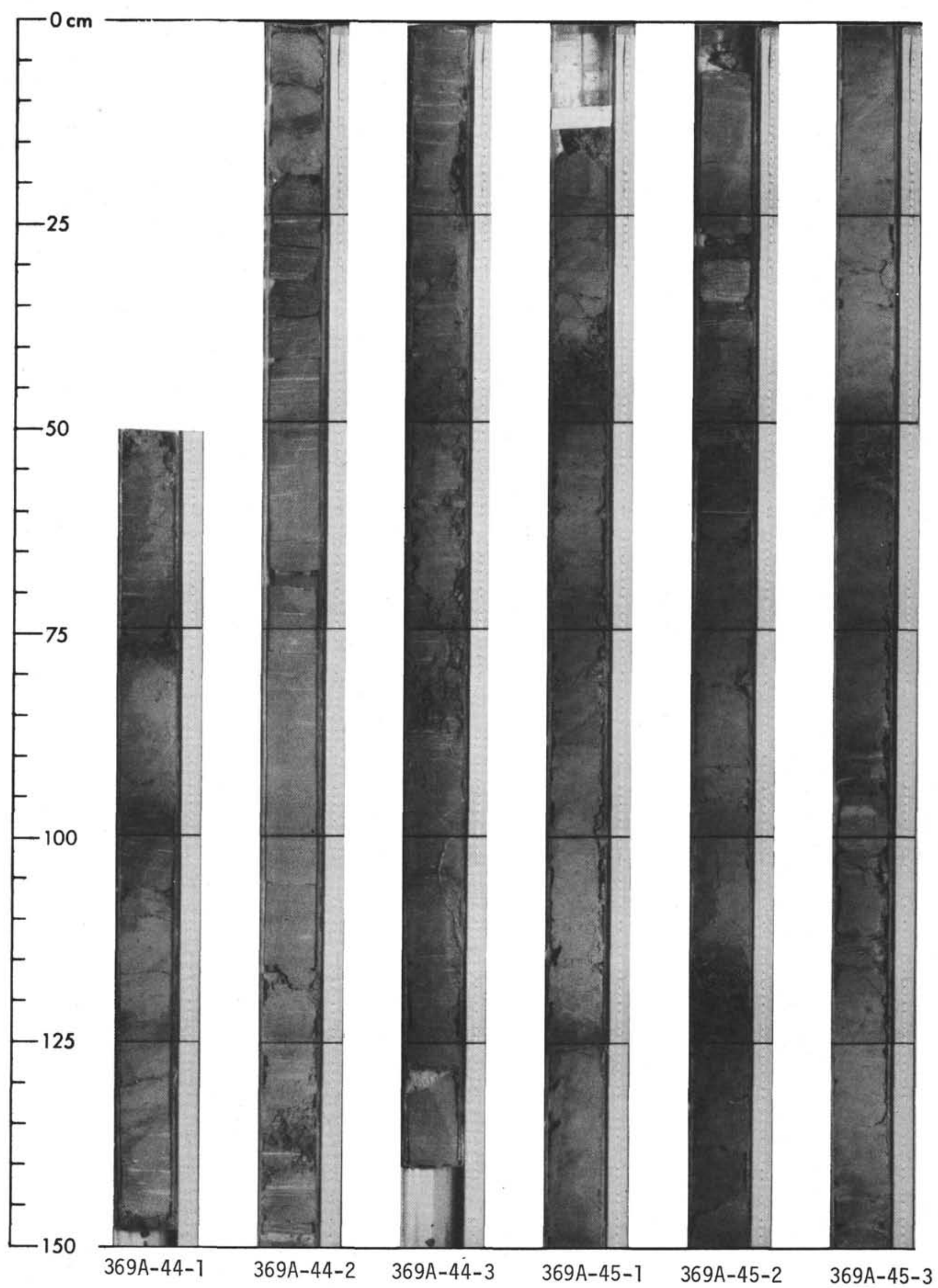




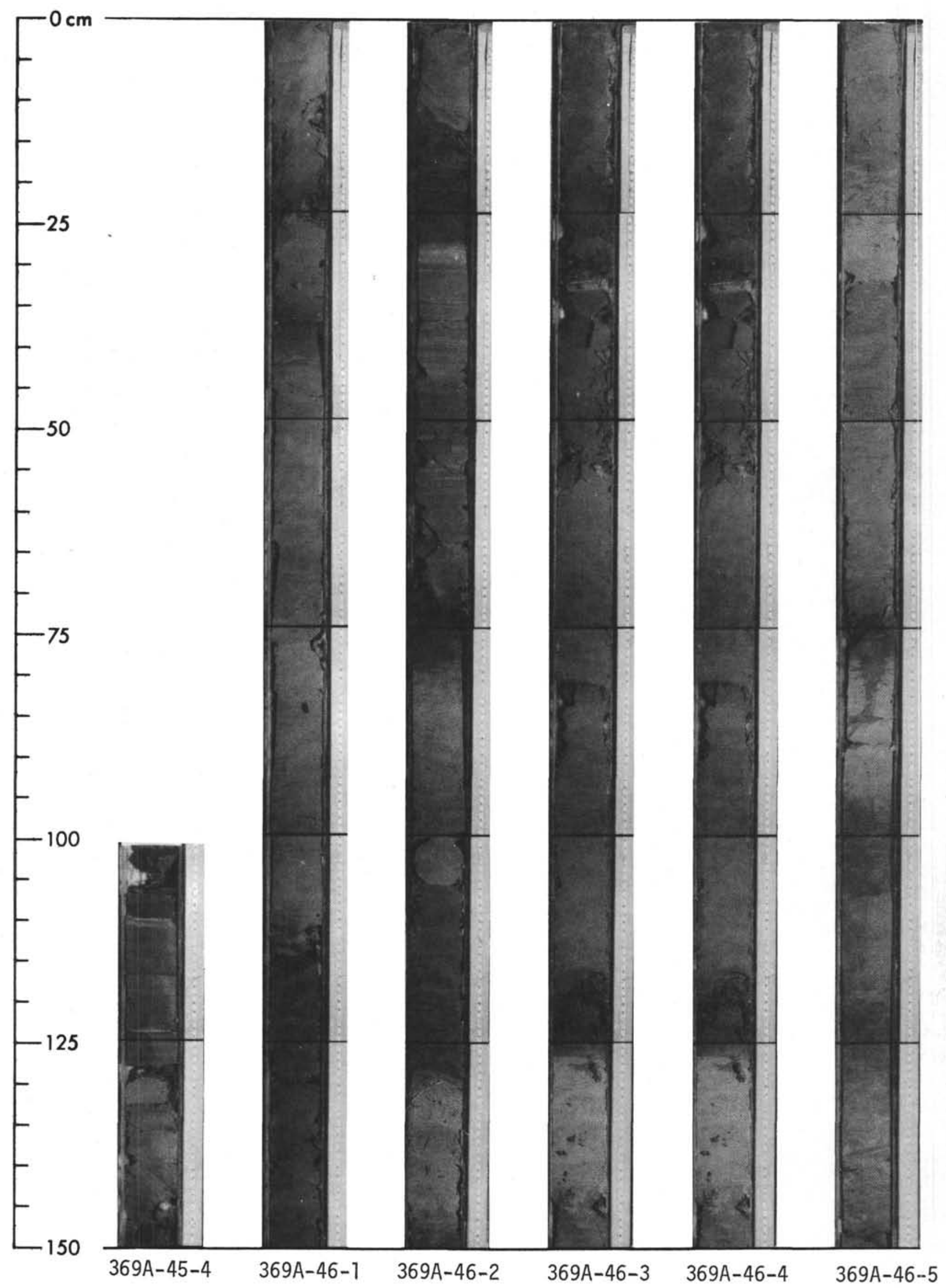




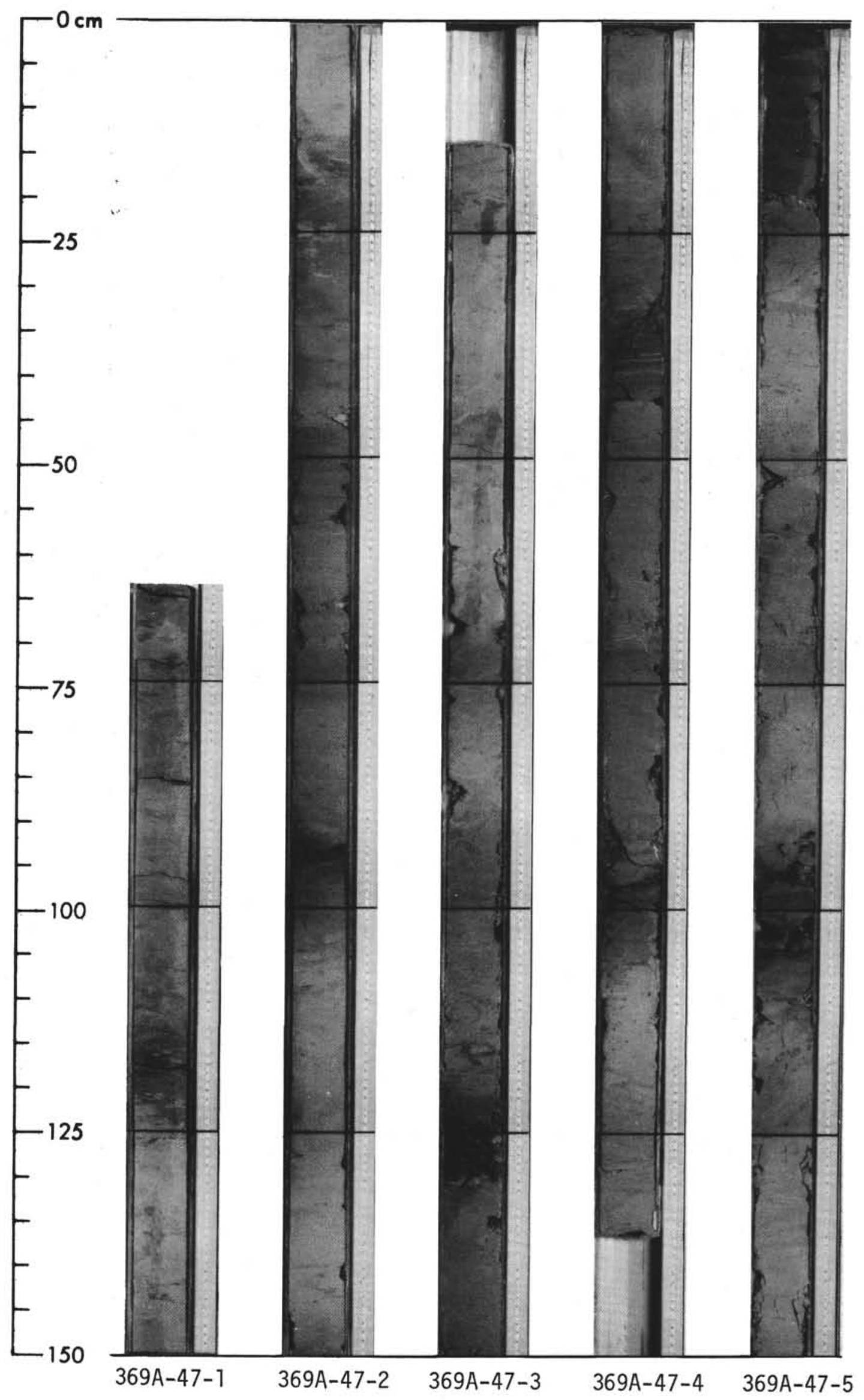

